\title{
Deepening Science Engagement with Challenge Based Learning: Research Report
}

\section{Emi Iwatani, Barbara Means, Maria R. Romero, and Mai Chou Vang}

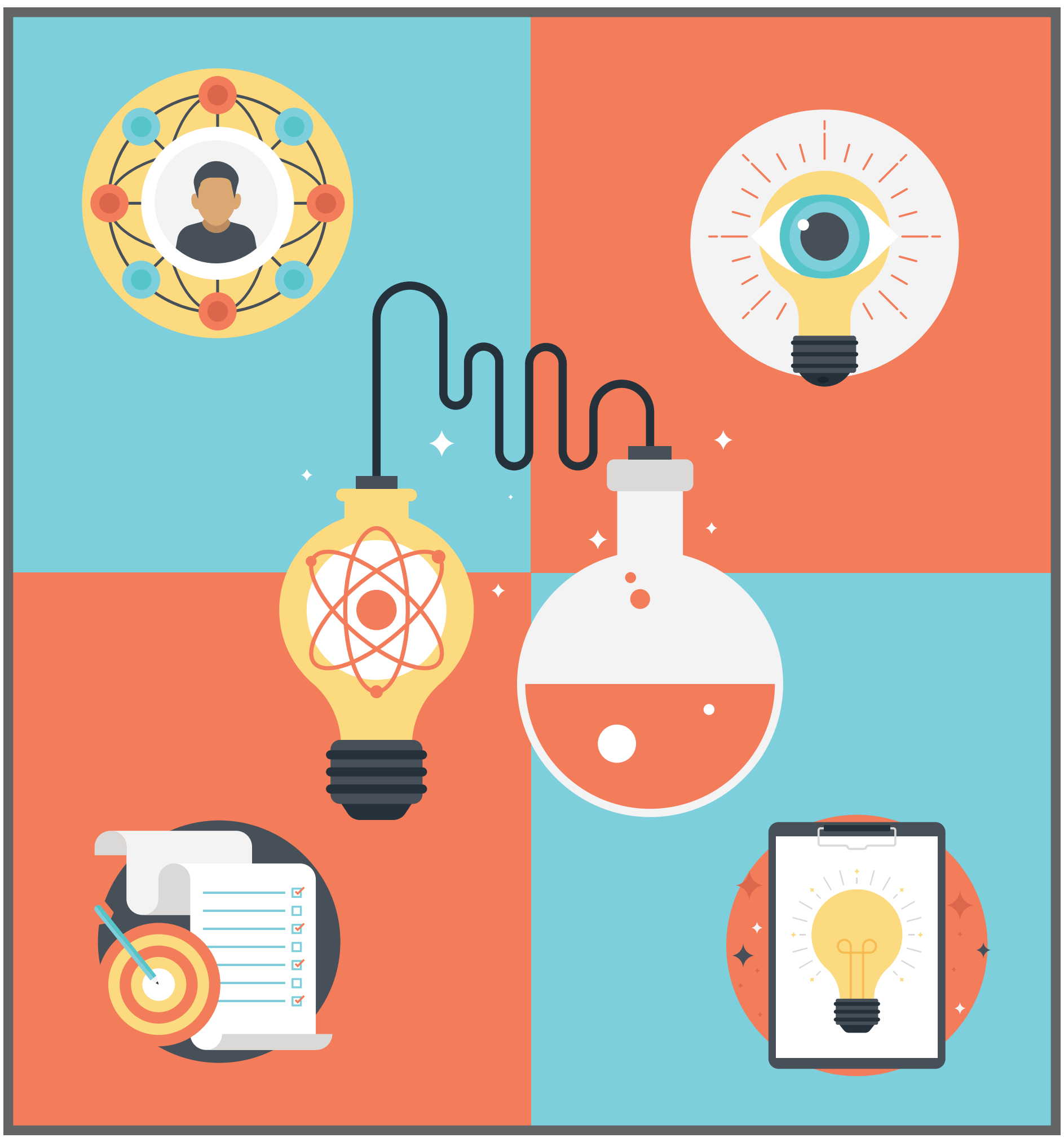




\section{Table of Contents}

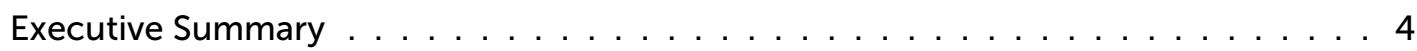

Section 1. About the Challenge Based Science Learning Project . . . . . . . . . . 10

Section 2. What Did the Challenge Based Science Learning Lessons Look Like? . . . . 14

Section 3. Deeper Learning Opportunities and Outcomes in

Challenge Based Lessons . . . . . . . . . . . . . . . . . . . . . . . 24

Section 4. Lessons for the Field. . . . . . . . . . . . . . . . . . . . . . . 35

Advice From Teachers . . . . . . . . . . . . . . . . . . . . . . . . 35

Advice From Students. . . . . . . . . . . . . . . . . . . . . . . . . . . . . . 39

Researcher Insights . . . . . . . . . . . . . . . . . . . . . . . . . 40

Section 5. Next Steps $\ldots \ldots \ldots \ldots \ldots \ldots \ldots \ldots \ldots$

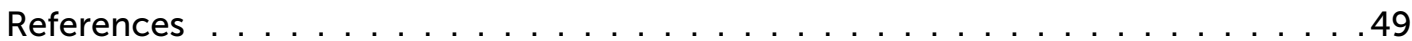

Appendix A. Methodological and Analysis Details . . . . . . . . . . . . . . . . 51

Appendix B. Activity Rubric . . . . . . . . . . . . . . . . . . . . . . . . .62

Appendix C. Student Work Rubric . . . . . . . . . . . . . . . . . . . . 68

Appendix D. Rubrics Used to Assess Opportunities and Outcomes

of Learning Grade-Appropriate Disciplinary Core Ideas ～. . . . . . . . . . . . . . . . 72

Appendix E. List of OER Found and Explored by Project Teachers. . . . . . . . . . . . 74 


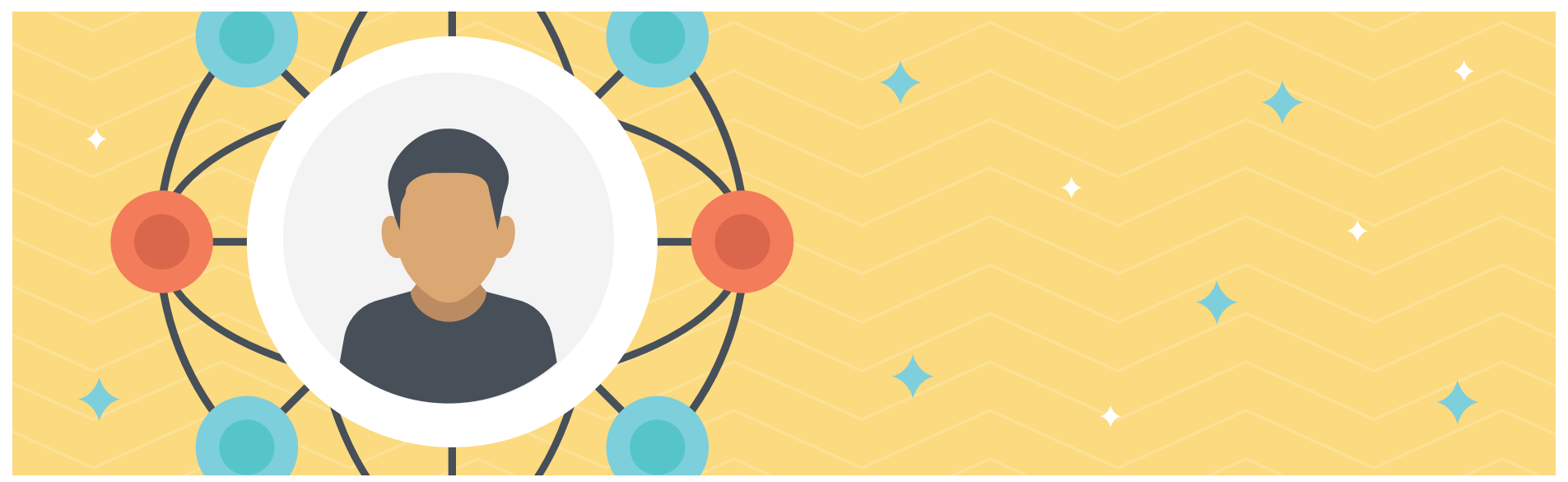

\section{Suggested Citation}

Iwatani, E., Means, B., Romero, M. R. \& Vang, M. C. (2020). Deepening Science Engagement with Challenge Based Learning: Research Report. San Mateo, CA: Digital Promise.

\section{Acknowledgments}

The research project described in this report was conducted with the support of the William and Flora Hewlett Foundation. We'd like to thank the teachers and administrators who participated in this project including: Lori Barker, Joseph Becker, Alissa Beinecke, Nicole Bianco, Marialice Cable, Dan Deguara, Kristin Deichler, Holly Eckhardt-Cooper, Jeff Evancho, Erica C. Frederick, Lorryn Goodman, Robyn Jordan, Jonathan Lam, Katherine Leist, Scott Litwinovich, Fran Morrison, Jason Neiser, Josh Patterson, Leslie Schafer, SeanPaul Richman, Teri Robinson, Gayle Van Fossen, Allyson Vera, and Annabelle Warner. We also thank Anthony Baker, Josh Weisgrau, and Karen Cator for their thought-partnership, the teachers and researchers who assisted in scoring teacher lessons and student work, and Rachael Brown, Carly Chillmon, Michelle Dreyband, Elyse Gainor, and Nathan Heidt for their expert design and editorial support. 


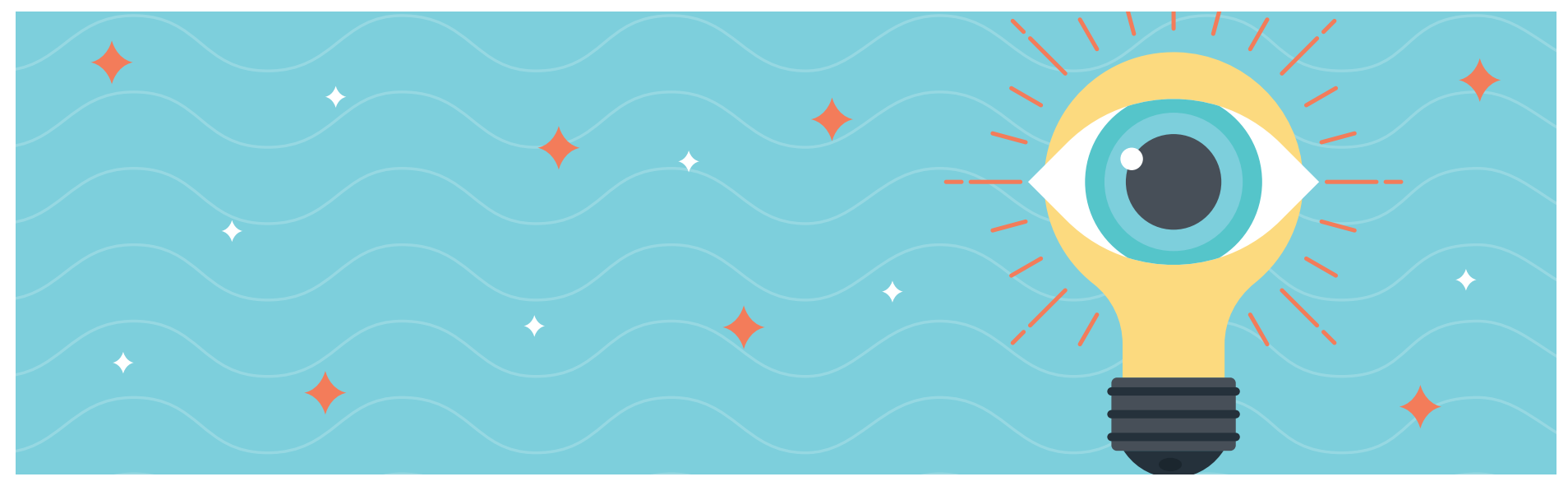

\section{Executive Summary}

\section{Introduction}

Throughout the 2018-19 school year, 18 middle school teachers and five administrators from three U.S. school districts partnered with instructional coaches and learning sciences researchers from Digital Promise to address an ambitious educational challenge: How might we deepen engagement and learning of middle school science in our schools and beyond? The overarching goals of the Challenge Based Science Learning Project, funded by the William and Flora Hewlett Foundation, included producing high-quality open educational resources (OER) for middle school science, and understanding whether and how activities built around these resources can promote deeper learning in science classrooms. Digital Promise organized this collaborative effort and also provided formative evaluation and research support.

The project's main activity was for teachers to create and implement science lessons that were "challenge based" and aligned with the Next Generation Science Standards (NGSS) (NGSS Lead States, 2013). Challenge Based Learning (CBL) is a type of problem-based learning distinguished by its requirement that students engage with, investigate, and act on authentic challenges they find personally meaningful (Cator \& Nichols, 2008; Nichols, Cator \& Torres, 2016). In accordance with this model, participating teachers designed science lessons where teachers prompted students with a phenomenon and had them come up with questions and a challenge to pursue. To align with NGSS, teachers identified in advance the set of disciplinary core ideas, science and engineering practices, and cross-cutting concepts that the challenges would target. 
The project's overall goals were to promote deeper learning in middle school science lessons and to strengthen the ecosystem of K-12 OER by drawing from and contributing to the existing pool of resources and supports. The project was experimental in nature: No one to our knowledge had tried combining CBL and NGSS in this way, or examined the impact of this combination on student learning. Furthermore, it was unclear whether a curriculum design project could impact use and development of OER in K-12 contexts. Synthesizing what we learned from 54 teacher interviews, more than 150 hours of classroom observations, 32 student focus groups, 71 samples of science lessons and associated student work, and participatory observations and participant surveys of two multi-day lesson design workshops, this report addresses the following questions:

1. What do teacher-created challenge based lessons aligned to NGSS look like?

2. If teachers make and implement challenge based lessons that are aligned to NGSS, does deeper learning occur more frequently?

3. What are lessons for the field? What are facilitators and barriers for standards-aligned challenge based learning? To what extent and in what ways do OER facilitate standards-aligned, challenge based science learning?

\section{Characteristics of the Challenge Based Science Learning Lessons}

Both CBL and NGSS focus on student-driven problem solving, with NGSS emphasizing three-dimensional learning of science, and CBL bringing student self-direction and engagement to the fore. Combining the pedagogical ideals of CBL and NGSS, teachers in this project produced 15 challenge based science lessons that had several features in common. They centered around complex, real-world issues; they involved rounds of student questioning and student-led research (usually online, secondary research); and they involved students learning and working toward a goal greater than simply "learning the material" or "getting a grade."

The lessons ranged from examining human impact on the environment to engineering solutions and addressing public health concerns. In each lesson, students typically engaged with an essential question about helping others 
through raising awareness or designing innovations. Teachers often encouraged students to generate questions about an intriguing phenomena to help them internalize the lessons' essential questions, and take ownership of their challenge. Students' investigations of their essential question fell under three main categories. All lessons involved some amount of secondary research, where students searched existing information to better understand phenomena and/or inform their design solutions. Many students also conducted science investigations and used engineering design practices to solve problems. Finally, the lessons called for students to take action and rise to their challenge, with most student action steps having to do with awareness raising, or with conceptualizing products to help the environment or improve the human condition.

When possible, teachers used open access resources to ensure that the lessons they created could be shared with other teachers without any copyright barriers. While teachers co-created a resource bank of existing middle school science OER, and were provided some time to explore these resources, most lessons teachers created did not rely substantially on existing OER in either design or conception. Teachers relied most heavily on their personal knowledge and experience with their students as well as practical considerations (e.g., taking into account the content that needs to be covered when the lesson will be implemented) to decide on their lesson topic. Once the lesson topic was decided, teachers typically used Google search to find relevant materials rather than looking through different OER websites.

Many aspects of the challenge based science lessons felt new and beneficial to most teachers, particularly student ownership of learning and the engagement that comes with it. Most students also saw the challenge based lessons as being very different from their normal lessons and appreciated the lessons' real-world relevance, the freedom to learn, and working with others. Teachers identified several areas in which the lessons could be improved, including sequencing and logistics, assessment, and promoting deeper research skills. 


\section{Deeper Learning Opportunities and Outcomes in Challenge Based Lessons}

The project compared challenge based lessons with lessons that teachers characterized as representative of what students usually do in their classes ("typical"), and lessons that were relatively well-aligned with at least one of the NGSS science and engineering practices ("NGSS practices-aligned"). Independent scorers scored the lessons and associated student work on rubrics that were designed to assess deeper learning and grade-appropriateness of science content.

The results were highly encouraging with respect to the potential for challenge based science lessons to provide deeper learning opportunities to students. On average, relative to typical lessons, challenge based science lessons substantially provided more opportunities for: real-world engagement, self-direction, practice of science and engineering skills, conducting critical research, substantive collaboration, and effective communication. Relative to NGSS practices-aligned lessons, the challenge based lesson scores were rated significantly higher in three of the six deeper learning dimensions (real-world engagement, critical secondary research, and effective communication) and equivalent in the remaining three areas (self-direction, practicing science and engineering, and substantive collaboration). Where challenge based lessons scored higher, they score higher by quite a lot (between 0.81 to 1.75 standard deviation units). Moreover, challenge based lessons did this while being just as strong as the two other types of lessons in terms of providing opportunity to learn grade-appropriate science content. Student work scores showed, unsurprisingly, that students' deeper learning outcomes are positively and strongly correlated with rating of the opportunities to learn deeply. It also confirmed teachers' and students' reports that students engaged more with the real world, did more secondary research, and communicated more often and more effectively in challenge based lessons.

These results also indicated that there is room for improvement in the challenge based lessons, especially in two areas: increasing opportunities for students to practice science investigations and engineering design, and to conduct secondary research more critically. Corroborating what the research team observed through classroom visits, the independent scorers who examined the challenge based lessons found that the deeper learning opportunities in these two areas, while stronger than the opportunities in typical lessons, were still just "emerging" (i.e., a score of approximately 1 ). So while challenge 
based lessons designed in this project significantly provided "more" opportunities than typical lessons (that scored on average approximately or a little over $0)$, the challenge based science lessons left room for improvement on this front.

\section{Lessons for the Field}

Many of the project teachers said their key takeaway was that it was difficult but worthwhile to let students drive some of their own learning students can rise to learning challenges when given the opportunity, and this type of learning can benefit all students, not just high achievers. Teachers found the lesson design process to be difficult because they had to step out of their comfort zone in many ways, and so much was left for them to figure out. They recommended that other teachers could benefit from having some examples of strong NGSS-aligned CBL units to start from. Finally, two teachers who were fully trained in project-based learning speculated that incorporating shorter-term CBL units, as teachers did in this project, might be a more scalable alternative than trying to shift teachers to doing all of their instruction through projects.

Students had advice as well, mainly for their teachers. They wanted the projects to be relevant and wanted enough time to work on them. They expressed a preference for doing "hands-on" activities, such as experiments and prototype building, rather than just reading about things on the internet.

We noticed, in addition, that student-centered, standards-aligned science teaching requires many skills, underscoring the importance of creating a rich learning ecosystem for teachers where these skills can be cultivated and developed. Particularly when a large transformation of values, beliefs, or behaviors is requested of teachers, professional learning experiences should: build on teachers' knowledge and expertise; be experiential, intense, and affective; be professionally relevant; be organized around value-laden goals; provide sustained opportunities for critical reflection; and be founded on authentic relationships.

\section{Next Steps}

The NGSS-aligned CBL units created through this project provide the content for a repository of middle school science materials Digital Promise has made available under a Creative Commons license. Future professional learning 
activities around student-centered, NGSS-aligned instruction can make use of these examples. A refined version of the rubrics used to rate deeper learning opportunities provided by the units and displayed in student work was also created. (Several of the rubric level definitions were refined based on suggestions from raters as well as reliability indices.)

Published examples of CBL science units and deeper learning rubrics can raise interest and awareness. However, to really achieve high-quality implementation of challenge based science learning, an investment in professional learning and support systems for science teachers is necessary. Despite national efforts to promote NGSS, less than half of all middle school science teachers emphasize learning how to do science in their classrooms and less than 10 percent emphasize learning how to do engineering. Sporadic half-day professional development sessions are not going to be sufficient to overcome the present over-reliance on teacher-directed transmission of science concepts. While not all teacher professional development can (or necessarily should) be as extended and participant centered as the teacher learning experiences in this project, initiatives that encourage teachers to radically change their instruction to a more student-centered approach will always need a significant experiential component.

The next logical line of inquiry involves figuring out a cost-effective approach to supporting teacher learning and culture change to emphasize more active, Challenge Based Learning. Prior experience would suggest that giving students encouragement and access to existing, NGSS-aligned CBL units would be insufficient to support high-quality implementation by most teachers. But it may not be necessary for teachers to design their own CBL units from scratch as they did in this project. A hybrid approach, in which teachers have examples of well-designed units and unit templates but engage in customizing the unit templates for their own students and curriculum, could reduce time requirements and teacher effort while still engendering a sense of ownership. We believe it is important, though, that any streamlined version of professional development around challenge based science learning preserve key qualities of this project, including leadership support, modeling of the target instructional approach, an ongoing learning community, and multiple iterations with feedback and reflection. 


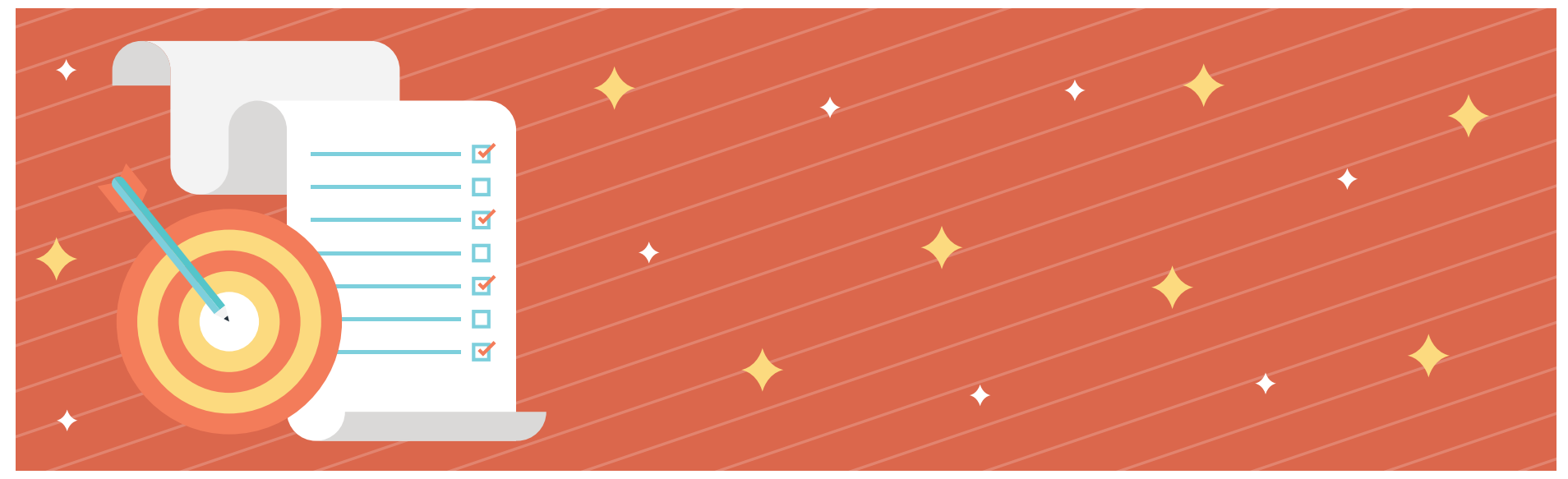

\section{Section 1. About the Challenge Based Science Learning Project}

Throughout the 2018-19 school year, 18 middle school teachers and five administrators from three US school districts, serving diverse student populations, ${ }^{1}$ partnered with instructional coaches and learning sciences researchers from Digital Promise to address an ambitious educational challenge: How might we deepen engagement and learning of middle school science in our schools and beyond? The overarching goals of the Challenge Based Science Learning Project, funded by the William and Flora Hewlett Foundation, included producing high-quality open educational resources (OER) for middle school science, and understanding whether and how activities built around these resources can promote deeper learning in science classrooms. Digital Promise organized this collaborative effort and also provided formative evaluation and research support.

As described in Table 1, the project incorporated a number of important big ideas in education, including Challenge Based Learning (CBL), deeper learning, three-dimensional science learning and open educational resources. The project's main activity was for teachers to create and implement science lessons that were "challenge based" and aligned with the Next Generation Science Standards (NGSS) (NGSS Lead States, 2013). CBL is a type of problem-based learning distinguished by its requirement that students engage with, investigate, and act on authentic challenges they find personally meaningful (Cator $\&$ Nichols, 2008; Nichols, Cator \& Torres, 2016). In accordance with this model, participating teachers designed science lessons where teachers prompted students with a phenomenon and had them come up with questions and a challenge to pursue. To align with NGSS, teachers identified in advance the set of disciplinary core ideas, science and engineering practices, and cross-cutting concepts that the challenges would target.

Most teachers worked in teams of two or three, co-designing the lesson with others who taught the same grade at the same school. To support teachers' design efforts, the

\footnotetext{
Teachers taught in five socioeconomically diverse public middle schools in three districts, serving grades six through eight. Eight teachers taught in Title I schools, with one school having high proportions of White and Black students, and the other predominantly Southeast Asian and Hispanic. Others taught in relatively affluent schools where the student population was either predominantly White, predominantly Southeast Asian, or predominantly White and South Asian. Enrollment was approximately 450 per grade, except in one school with approximately 250 per grade. Districts were recruited through a national network of forward-thinking superintendents and selected based on their stated interest and capacity to develop and implement challenge based NGSS-aligned curricula.
} 
project's initial two-day workshop introduced NGSS and CBL concepts, and provided models of $C B L$ instruction and resources for the teacher teams to use in designing their lessons. The second workshop provided opportunities for teachers to reflect together on their first experience with such lessons and to design a second lesson. District leads not only participated in the workshops and helped provide professional development time and resources, but also supported the teachers instructionally and emotionally (Jordan, 2019). The research team conducted teacher interviews, classroom observations, and student focus groups both before and after teachers attended the design workshops. The project timeline is provided in Table 2.

Table 1. Big Ideas That Informed the Challenge Based Science Learning Project

\begin{tabular}{|c|c|c|}
\hline Big Idea & Briefly, what it is & $\begin{array}{l}\text { Why it was important for the } \\
\text { project }\end{array}$ \\
\hline $\begin{array}{l}\text { Challenge } \\
\text { Based } \\
\text { Learning } \\
\text { (CBL) }\end{array}$ & $\begin{array}{l}\text { A type of problem-based learning } \\
\text { where students learn by identifying } \\
\text { and rising up to an authentic challenge } \\
\text { in their community. CBL requires } \\
\text { students to engage with, investigate, } \\
\text { and act upon their chosen real-world } \\
\text { challenges. See CBL website and CBL } \\
\text { Publications and Research for more. }\end{array}$ & $\begin{array}{l}\text { Middle school is an important } \\
\text { period when students become more } \\
\text { self-conscious, socially aware, and } \\
\text { independent-minded. We wanted to } \\
\text { support students in their developmental } \\
\text { growth trajectory by having them start } \\
\text { to drive their own learning and connect } \\
\text { what they were learning with the world } \\
\text { around them. CBL provided a specific } \\
\text { pedagogy to do this. }\end{array}$ \\
\hline $\begin{array}{l}\text { Deeper } \\
\text { Learning }\end{array}$ & $\begin{array}{l}\text { "[A]n umbrella term for the skills } \\
\text { and knowledge that students must } \\
\text { possess to succeed in } 21 \text { st century } \\
\text { jobs and civic life. At its heart is a set of } \\
\text { competencies students must master in } \\
\text { order to develop a keen understanding } \\
\text { of academic content and apply } \\
\text { their knowledge to problems in the } \\
\text { classroom and on the job" } \\
\text { (Hewlett, 2013). }\end{array}$ & $\begin{array}{l}\text { We wanted students to learn science } \\
\text { more "deeply" rather than just memorize } \\
\text { facts and skills. The deeper learning } \\
\text { scholarship helped identify what we } \\
\text { might want to attend to in student } \\
\text { learning, beyond test scores. }\end{array}$ \\
\hline $\begin{array}{l}\text { Three- } \\
\text { Dimensional } \\
\text { Science } \\
\text { Learning }\end{array}$ & $\begin{array}{l}\text { "Three-dimensional learning shifts } \\
\text { the focus of the science classrooms } \\
\text { to environments where students use } \\
\text { disciplinary core ideas, cross-cutting } \\
\text { concepts with scientific practices to } \\
\text { explore, examine, and explain how and } \\
\text { why phenomena occur and to design } \\
\text { solutions to problems" (Krajcik, n.d.). }\end{array}$ & $\begin{array}{l}\text { We wanted students to learn science in } \\
\text { ways that are supported by the leading } \\
\text { science education standards and that } \\
\text { would support their success with any } \\
\text { assessments that might be aligned to } \\
\text { these standards. All districts participating } \\
\text { in the project were located in states that } \\
\text { had adopted or were soon to adopt } \\
\text { the NGSS. }\end{array}$ \\
\hline $\begin{array}{l}\text { Open } \\
\text { Educational } \\
\text { Resources }\end{array}$ & $\begin{array}{l}\text { "Teaching, learning and research } \\
\text { materials in any medium-digital or } \\
\text { otherwise-that reside in the public } \\
\text { domain or have been released } \\
\text { under an open license that permits } \\
\text { no-cost access, use, adaptation and } \\
\text { redistribution by others with no or } \\
\text { limited restrictions" (․ewlett, n.d.). }\end{array}$ & $\begin{array}{l}\text { We wanted any lessons and ideas that } \\
\text { were created from this project to be } \\
\text { easily and freely shared with other } \\
\text { teachers around the world. }\end{array}$ \\
\hline
\end{tabular}


Table 2. Challenge Based Science Learning Project Timeline

\begin{tabular}{|l|l|l|l|l|l|}
\hline & $\begin{array}{l}\text { Baseline } \\
\text { Visits }\end{array}$ & $\begin{array}{l}\text { Design } \\
\text { Workshop \#1 }\end{array}$ & $\begin{array}{l}\text { First } \\
\text { Implementation } \\
\text { Round }\end{array}$ & $\begin{array}{l}\text { Design } \\
\text { Workshop \#2 }\end{array}$ & $\begin{array}{l}\text { Second } \\
\text { Implementation } \\
\text { Round }\end{array}$ \\
\hline Timing & Nov 2018 & Dec 2018 & Jan-Feb 2019 & Mar 2019 & Mar-May 2019 \\
\hline $\begin{array}{l}\text { Design } \\
\text { Activities }\end{array}$ & $\begin{array}{l}\text { Baseline visit } \\
\text { to introduce } \\
\text { the project and } \\
\text { learn about } \\
\text { the learning } \\
\text { context }\end{array}$ & $\begin{array}{l}\text { Introduction to } \\
\text { CBL and NGSS } \\
\text { Design first } \\
\text { challenge } \\
\text { based science } \\
\text { lesson }\end{array}$ & $\begin{array}{l}\text { Design first } \\
\text { challenge based } \\
\text { science lesson }\end{array}$ & $\begin{array}{l}\text { Explore OER } \\
\text { and deeper } \\
\text { learning }\end{array}$ & $\begin{array}{l}\text { Implement } \\
\text { second challenge } \\
\text { based science } \\
\text { lesson }\end{array}$ \\
\hline $\begin{array}{l}\text { Research } \\
\text { Activities }\end{array}$ & $\begin{array}{l}\text { Teacher } \\
\text { interviews, } \\
\text { observations, } \\
\text { collection of } \\
\text { lessons and } \\
\text { student work }\end{array}$ & $\begin{array}{l}\text { Participatory } \\
\text { observation, } \\
\text { perception } \\
\text { surveys }\end{array}$ & $\begin{array}{l}\text { Observations, } \\
\text { teacher interviews, } \\
\text { student focus } \\
\text { groups, collection } \\
\text { of lessons and } \\
\text { student work } \\
\text { lesson. }\end{array}$ & $\begin{array}{l}\text { Participatory } \\
\text { observation, } \\
\text { perception } \\
\text { surveys }\end{array}$ & $\begin{array}{l}\text { Observations, } \\
\text { teacher interviews, } \\
\text { student focus } \\
\text { groups, collection } \\
\text { of lessons and } \\
\text { student work }\end{array}$ \\
\hline
\end{tabular}

As noted above, the project's overall goals were to promote deeper learning in middle school science lessons and to strengthen the ecosystem of K-12 open educational resources (Huttner, Green, \& Cower, 2018) by drawing from and contributing to the existing pool of resources and supports. The project was experimental in nature: No one to our knowledge had tried combining CBL and NGSS in this way, or examined the impact of this combination on student learning. Furthermore, it was unclear whether a curriculum design project like this could impact use and development of OER in K-12 contexts. The research aspects of the project addressed the following questions:

1. What do teacher-created challenge based lessons aligned to NGSS look like?

2. If teachers make and implement challenge based lessons that are aligned to NGSS, does deeper learning occur more frequently?

3. What are lessons for the field? What are facilitators and barriers for standards-aligned CBL? To what extent and in what ways do OER facilitate standards-aligned, challenge based science learning?

Our report synthesizes what we learned from 54 teacher interviews, more than 150 hours of classroom observations, 32 student focus groups, and participatory observations and participant surveys of two multi-day lesson design workshops. Furthermore, to better understand deeper learning opportunities and outcomes, we collected and analyzed 71 samples of middle school science lessons and associated student work-both challenge 
based lessons and not. The lessons were scored by independent scorers, using rubrics that the research team developed for the project. One set of rubrics concerned deeper learning opportunities that the lesson or activity provided to students and consisted of rubrics for six dimensions of deeper learning opportunities. Another set was for rating evidence of deeper learning that could be seen within the student work and consisted of rubrics for five dimensions. More details about the scoring process and results are provided later in this report (Section 3, Appendix A) as well as in a technical report by Iwatani, Vang, Romero, and Means (forthcoming). 


\section{Section 2. What Did the Challenge Based Science Learning Lessons Look Like?}

\section{Common features of challenge based science lessons and their connections to NGSS and CBL}

Consensus around critical features of NGSS-aligned lessons has emerged (Next Generation Science Standards, 2016). First, the lessons should focus on students using science and engineering practices to explain phenomena or design solutions to a problem. In addition, lessons should focus on helping students develop all three dimensions of the standardsscience and engineering practices, disciplinary core ideas, and cross-cutting concepts-at the appropriate grade level and in an integrated way. Ideally then, students are learning science content, skills, and cross-cutting ideas all at the same time as they explain science phenomena and engineer solutions. High-quality science lessons, according to the NGSS, must also be authentic and relevant, provide ample opportunities for students to communicate and refine their ideas, and explicitly identify and build on students' prior learning in all three dimensions.

Some of these core features of NGSS-aligned lessons overlap with central features of high-quality challenge based learning lessons. Challenge based lessons must be relevant, driven by student curiosity, involve substantial student choice, foster student self-direction, and empower students to act to help others or provide value to their community. Thus, both frameworks focus on student-driven problem solving, with NGSS emphasizing three-dimensional learning of science, and CBL bringing student self-direction and engagement to the fore.

Combining the pedagogical ideals of CBL and NGSS, teachers in this project produced 15 challenge based science lessons that had several features in common (Table 3). They centered around complex, real-world issues; they involved rounds of student questioning and student-led research (usually online, secondary research); and they involved students learning and working towards a goal greater than simply "learning the material" or "getting a grade." 


\begin{tabular}{|c|c|c|}
\hline Lesson Features & Tie to CBL & Tie to NGSS \\
\hline $\begin{array}{l}\text { Centers Around Complex } \\
\text { Real-World Issue: Students are } \\
\text { introduced to a complex, real- } \\
\text { world issue that defies simple } \\
\text { explanations and solutions. }\end{array}$ & Relevance, curiosity & $\begin{array}{l}\text { Precursor to explaining } \\
\text { phenomena or designing } \\
\text { solutions, anchoring } \\
\text { phenomena }\end{array}$ \\
\hline $\begin{array}{l}\text { Questioning: Students arrive } \\
\text { at a question of personal } \\
\text { importance, after extended } \\
\text { questioning about a real-world } \\
\text { problem or phenomenon of } \\
\text { personal relevance. }\end{array}$ & $\begin{array}{l}\text { Relevance, curiosity, student } \\
\text { choice, student self- } \\
\text { direction, acting to } \\
\text { help others }\end{array}$ & $\begin{array}{l}\text { Anchoring phenomena, asking } \\
\text { questions (a science and } \\
\text { engineering practice) }\end{array}$ \\
\hline $\begin{array}{l}\text { Self-Guided Research: Students } \\
\text { guide their own learning to } \\
\text { better understand and act } \\
\text { upon their essential question. } \\
\text { This invariably involves some } \\
\text { online research, and sometimes } \\
\text { involves science investigations } \\
\text { and engineering design } \\
\text { processes. }\end{array}$ & $\begin{array}{l}\text { Relevance, curiosity, } \\
\text { student self-direction }\end{array}$ & $\begin{array}{l}\text { Three science and engineering } \\
\text { practices: obtaining and } \\
\text { communicating information, } \\
\text { planning and carrying out } \\
\text { investigations (in some lessons), } \\
\text { and constructing explanations } \\
\text { and designing solutions }\end{array}$ \\
\hline $\begin{array}{l}\text { Learning and Working Toward a } \\
\text { Greater Goal: Students address } \\
\text { their essential question. }\end{array}$ & $\begin{array}{l}\text { Relevance, student self- } \\
\text { direction, acting to } \\
\text { help others }\end{array}$ & Designing solutions \\
\hline
\end{tabular}

\section{What the lessons looked like in practice}

Teachers spent a great deal of care and time in selecting their lesson topics, with many reporting difficulty identifying a topic that both engaged students and incorporated all the content and skills that needed to be addressed. The resulting lessons ranged from examining human impact on the environment to engineering solutions and addressing public health concerns. In each lesson, students typically engaged with an essential question about helping others through raising awareness or designing innovations (Figure 1). 


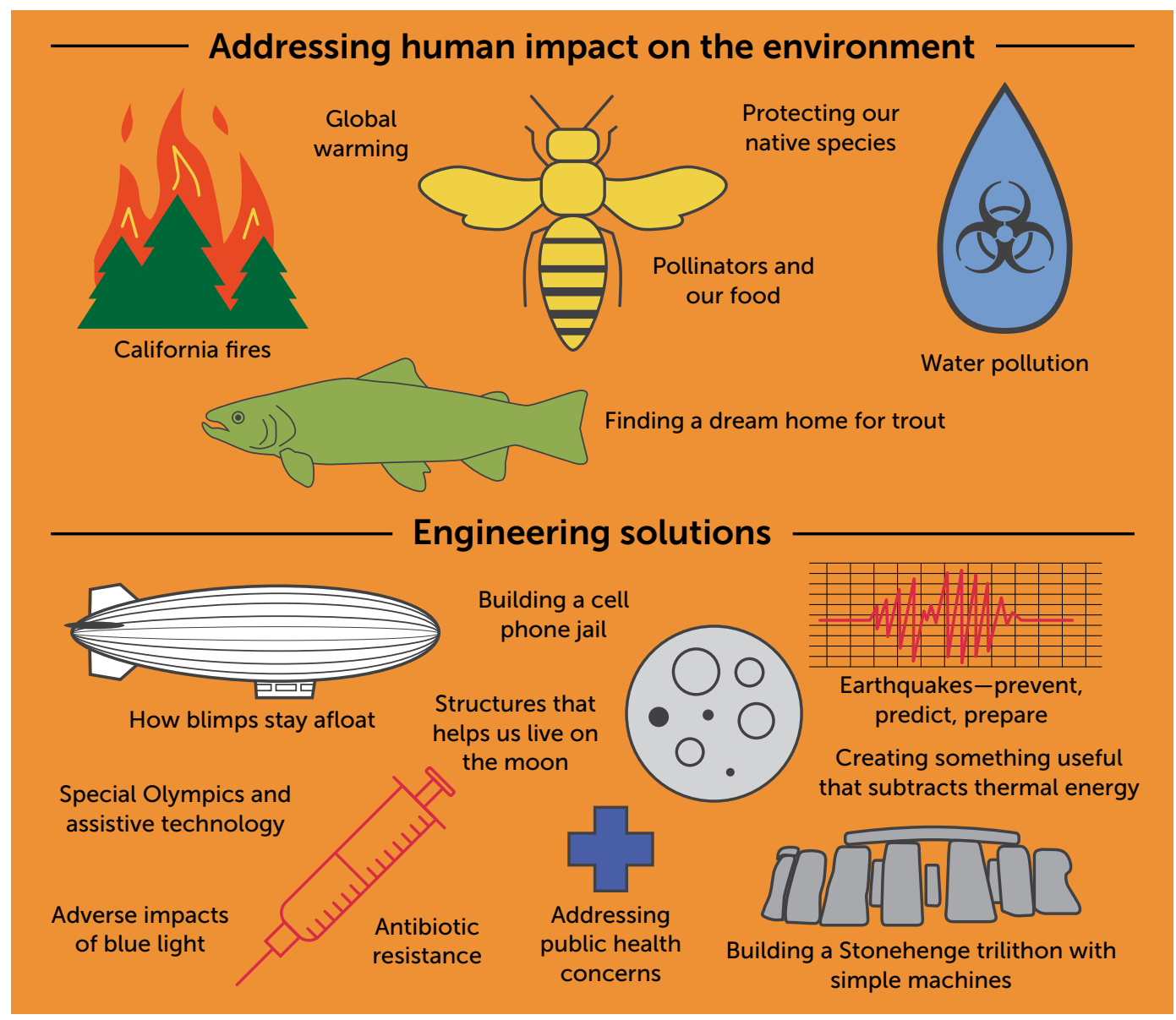

Figures 2 and 3 illustrate two challenge based science lessons created through this project. More examples of lessons are provided in "CBL for NGSS toolkit" (2020). In keeping with the $\mathrm{CBL}$ framework, in each lesson students engaged with an essential question and challenge, conducted investigations, and took some action to make a difference. 


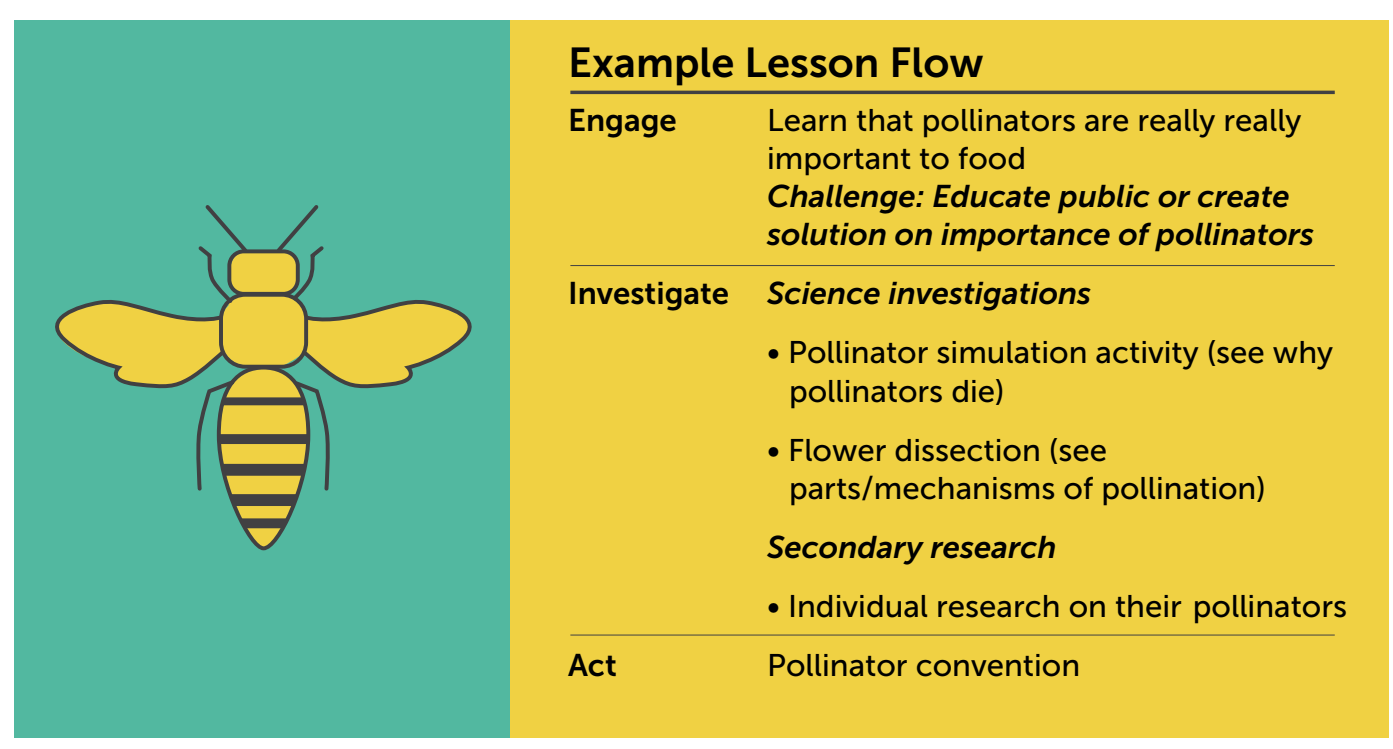

Figure 3. Example \#2 of Challenge Based Science Lessons Created

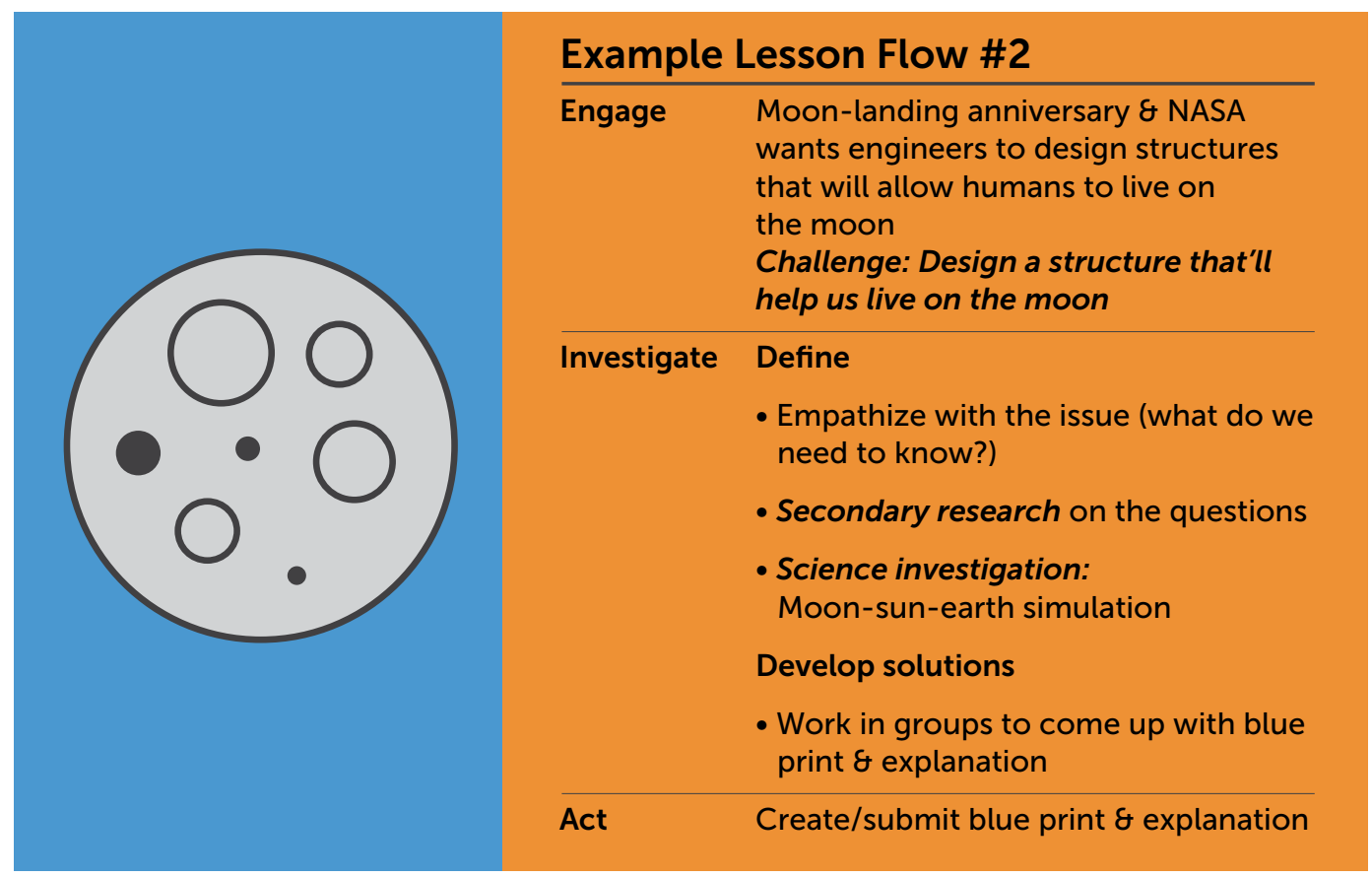

\section{Engaging with the essential question}

Teachers used different strategies to help students internalize and take ownership of the lessons' essential questions so that they would be motivated to engage with their challenge. Many teachers decided to do this by introducing students to an intriguing phenomenon related to the lesson topic (e.g., through storytelling, showing a video or images, reading a news article, or inviting a guest speaker) and letting students' questions about the phenomenon drive the rest of the lesson. This is an approach commonly used in 
conjunction with inquiry approaches to science education (e.g., Next Generation Science Storylines, CREATE for STEM, inquiryHub). Students were often asked to write down their questions on sticky notes. These questions were then pooled, shared, and categorized either as a whole class or in small groups. In some lessons, teachers guided students to come up with the essential question through a questioning process, while in other lessons the teachers used the questioning process to get students to begin to respond to the essential question.

\section{Three kinds of student investigations}

Students' investigations of their essential question fell under three main categories. All lessons involved some amount of secondary research, where students searched existing information to better understand phenomena and/or inform their design solutions. For example, eighth graders who were trying to help their schoolmates more comfortably participate in the Special Olympics looked for information on a variety of topics, such as "What is the Special Olympics?" and "What are the causes/symptoms of the special needs conditions that our friends have?"

Students also conducted science investigations, or activities that allowed them to discover scientific principles through firsthand experience in contrast to reading and summarizing what has already been discovered. These included dissections, simulations, experiments, and field work. For example, seventh graders who were educating others about the importance of pollinators dissected flowers to deeply understand what pollen looks and feels like and how it is related to the rest of the flower. Students also participated in a bee simulation that allowed them to "see" how environmental and human factors led to increases and decreases in the bee population. Not all science lessons involved science investigations (i.e., some lessons involved only secondary research), however, which meant that students lacked opportunities to engage in the NGSS science and engineering practices involved in conducting primary investigations (e.g., planning and carrying out investigations, analyzing and interpreting data, engaging in argument from evidence, and using mathematics and computational thinking). This is an area that could and should be improved in future iterations of this type of professional learning initiative.

The third investigation type was students' use of engineering design practices to solve problems. NGSS construes "engineering" broadly, "to mean any engagement in a systematic practice of design to achieve solutions to particular human problems" (National Research Council, 2012, p.11-12). NGSS also maintains that the general practices of engineering design ("defining and delimiting engineering problems," "designing solutions to engineering problems," and "optimizing the design solution") should be taught broadly in science classes because they are "practices that all citizens should learn" (Next Generation Science Standards, 2013, p.1). Engineering design shares commonalities but "has a different purpose and product than scientific inquiry" (Next Generation Science Standards, 2013, p.1), namely that engineering is about using a design process to develop solutions, while the goal of science inquiry is to understand and explain phenomena. Learning one kind of practice does not necessarily imply learning of the other, although scientific inquiry is often 
an essential aspect of engineering (e.g., conducting experiments to see what materials work best for a thermos), and engineering of new tools or processes is often essential to new science discoveries (e.g., the importance of X-ray crystallography to the identification of the structure of DNA). As seen in Figure 1, many of the challenges developed through this project involved engineering a new solution. For example, sixth graders designed structures that would allow us to comfortably live on the moon, after doing some secondary research and science investigations to understand how the lunar day is different than a day on Earth. Many engineering lessons did not explicitly invoke the practices of engineering design, however. Students were not often asked to specify criteria and constraints of successful solutions, or to systematically compare different solutions to arrive at optimal designs, making this another area for improvement for similar initiatives in the future.

\section{Students taking action to make a difference}

The third and final stage of $\mathrm{CBL}$ is for students to take action and rise to their challenge. In the CBL units designed in this project, most actions had to do either with awareness raising, or with conceptualizing and/or creating products or processes to help the environment or improve the human condition. In some lessons, teachers gave students some choice on how they could "act." For example, students could try to help plan for, prepare against, predict or prevent an earthquake. This resulted in students creating anything from earthquake kits, to blueprints of earthquake proof desks and buildings. In other lessons, teachers placed more constraints on what students could do in the action phase of the CBL unit (e.g., everyone had to create a 30 -second public service announcement about antibiotic resistance or to create a container that keeps things cool), but students had freedom on several key elements of design and execution.

\section{Use of open educational resources}

When possible, teachers used OER to ensure that the lessons they created could be shared with other teachers without any copyright barriers. While teachers co-created a resource bank of existing middle school science OER (Appendix E) and were provided some time to explore these resources, most lessons teachers created did not rely substantially on existing OER in either design or conception. Teachers relied most heavily on their personal knowledge and experience with their students, as well as practical considerations (e.g., taking into account the content that needs to be covered when the lesson will be implemented) to decide on their lesson topic. Once the lesson topic was decided, it seemed more efficient to Google search for relevant materials rather than look through different OER websites on the chance that they would contain something relevant to the planned challenge. ${ }^{2}$

\footnotetext{
Middle school science OER can exist in large extended units (e.g., sample units in OpenSciEd) and in smaller instructional bits (e.g., single lessons, rubrics, and activities). If teachers are looking for something very specific to insert into their lesson, the Google strategy is simpler. They might have had more incentive to look at OER sites if they were looking for examples of whole learning activities.
} 


\section{What felt new and beneficial for teachers}

\section{Student engagement}

The vast majority of project teachers thought students seemed very engaged with their CBL lessons, relative to the lessons they usually teach. Teachers thought that students may have been engaged by the phenomena, by the ownership of their learning, and/or by having their question read aloud and considered by the entire class.

\section{Trusting students to ask good questions and research them on their own}

Asking students to formulate and pursue questions was a very different approach from most teachers' typical practice. For many teachers, asking students to do more of the questioning and thinking worked out better than they had expected, which was a pleasant surprise. "I was surprised that the kids came up with some good questions, and that they came up with questions that I wanted them to ask," said one teacher, "And it's basically the questions a teacher would ask, but they actually generated the question." The project required teachers to trust their students in ways they don't typically think to do. Another veteran teacher shared: "We're used to ingraining the content with our lessons, so lit feels different that we're] relying on the kids to learn the content and trusting that they're going to be dedicated enough."

\section{Getting students to discover information rather than to receive and practice it}

On a related issue, many teachers pointed out that the challenge based lessons were different than their usual practice because students were discovering and constructing knowledge themselves in an open-ended environment, rather than "taking notes and practicing things." As several teachers pointed out, this had to do with the sequence of the lesson being very different than in most teaching. Appreciating NGSS experts' advice that it is more effective to flip the common practice of "frontloading" students with information instead using activities to motivate obtaining needed information, one eighth-grade teacher remarked:

The other thing that I really learned from this is the information the kids can pick up that you do not have to introduce in the beginning ... I did not need to frontload any information. I didn't need to frontload vocab. I didn't need to frontload concepts ... I didn't really have to tell them that much about MD Olympics or disabilities. They figured all of that out on their own.... [E]ven with the prototyping and all that kind of stuff, I didn't have ... we didn't have to sit there and have a lesson on "How do you make a lever?" They just figured it out.

\section{Learning more about students}

The project provided extended opportunities for teachers to observe how students behave when they need to figure things out on their own. On the one hand, teachers saw many ways that students are capable of guiding their own learning. Teachers observed, for example, that many of their students can productively generate and pursue science questions, 
reason more deeply than they might have expected, come up with creative ideas, learn from failure, use technology effectively, and work together naturally and productively. On the other hand, teachers also were able to see new areas in which students struggled. Several teachers observed that their students were not used to thinking for themselves, and needed more support. An eighth-grade teacher shared:

They're not used to questioning themselves or questioning what we're doing. Again, they're spoon-fed, "Here's this information." So if they're asking questions, [they wonder] "What kind of questions should I ask?" So, I think moving forward, that's a concept that we need to address.

Other teachers made similar observations about students' lack of experience in questioning, sensemaking, and intellectual risk-taking. Some observed that many of their students didn't know how to conduct secondary research (e.g., they relied on Google Images and avoided reading). Others realized their students were not as good as they had assumed in applying concepts to solve new problems. In addition, others remarked that students were not used to pursuing or trying to address "root causes" of problems. Gaining a better understanding of their students' areas of strength and weakness provided teachers with ideas about their future lessons.

\section{What felt new and beneficial for students}

\section{Real-world learning, independence, and enjoyment}

Many of the challenge based science lessons presented students with authentic and relevant challenges and topics. Students explored pressing issues affecting their daily lives including global warming and the loss of pollinators. Some students explored topics important to their community, such as a challenge to help another classroom with a Special Olympics event. As final projects, some of the lessons asked students to create or design solutions that a person might use. For example, in a classroom where students were exploring the harmful effects of water pollution, one group of students designed a water filter. This process of being presented with a real problem and thinking through how to address it was a new type of learning for some students.

Students enjoyed participating in the challenge based science lessons which they saw as very different from their normal lessons. For some, it was an opportunity to explore a new topic; for others it allowed them to gain experience doing research or developing a solution. One student mentioned that what they enjoyed most was being able to lead their own learning. This was different from their normal science lessons in that students explored a topic they cared about rather than a topic someone else thought they needed to learn. An eighth-grade student said:

I just like how [the teachers] gave us a lot of independence. That was the main part. They just gave us a lot of freedom of, "Do what you want, and make sure that you actually care for the project." Usually what we do in science was always like, "We want you to learn this. That's why we're giving you this thing to do." This was mostly for the 
environment. We actually needed to do this, and it actually mattered, not just for us to learn. It actually mattered for, I don't know, the environment. They did give us a lot of responsibility and freedom to make our choices.

Several also appreciated being able to help others. For example, in one lesson where students were challenged to think through how they might help their friends in another classroom participate in a Special Olympics event, they designed a prototype to make participation in a throwing event easier. Students who participated in this lesson shared that it opened up their knowledge about the types of disabilities that exist and their impact on a student. It allowed them to practice considering other perspectives and empathy. One eighth-grade student shared:

[l enjoyed the lesson] because I didn't know some of the disabilities that some people have. I didn't know what they were, and it was cool learning about them. And the challenges they go through. Because if we wouldn't have done that lesson, I would have no clue.

\section{Hands-on; Being like a scientist}

As mentioned, several of the challenge based science lessons gave students the opportunity to dig into the science topics they were learning firsthand. In one class, students were given the challenge of identifying a stream into which to release their class trout. As part of this activity, the teachers brought stream samples from multiple sources filled with sediment and invertebrates for the students to examine and analyze to inform their decision. One eighth-grade student shared that they appreciated having the chance to do this on their own rather than directly hearing from the teacher what the conditions of each stream were:

We saw a bunch of tadpoles. I like the hands-on experience, not with the field trip but with the lesson before [in the classroom]. [Rather than the teacher] just saying things like "we saw this, and this, and this, and the temperature was right, so we're going to" ... we got to actually see what was in the water and what the trout would end up living in.

Students who had the opportunity to do dissections, experiments, simulations, and engineering design activities expressed similar sentiments of appreciation. 


\section{Working with others}

Students also appreciated having the opportunity to work with friends in groups. Many of the challenge based science lessons provided an opportunity for students to conduct research, present, or build prototypes with another person or a group. For some students, this difference stood out as a benefit. One seventh-grade student mentioned this opportunity because it allowed for their group to figure out how they would address their challenge together:

The cool thing was that everyone got to choose whatever they wanted to do. Each block, I think, got to sort of make their own question that they had to solve, but it was almost the same one for every block. And then we split off into groups, right? So then we were able to make our own choices on what we wanted to do as a project. Like my group made an app while other groups made an invention to stop all the pollution going out into the air.

\section{Expanding their view of the world}

Through this project, students addressed challenges related to global warming and its effect on food production, antibiotic-resistance, and the impact of blue light. These authentic complex challenges allowed students to expand their understanding by developing their own opinions related to these topics. In one lesson, where students worked towards developing solutions for global warming, a seventh-grade student reflected back on learning about this topic and realizing how pressing and relevant it is for them today:

I knew it had an impact, but I didn't realize how big it was until we did this unit. I thought it was just something that was on the back burner, just like there but it didn't really impact us that much.

\section{Areas for further improvement}

Teachers identified several areas they wanted to work on or still had questions about. Many of their thoughts for improvement had to do with sequencing and logistics of their lesson, especially around how the student questioning can be smoother, or how the project requirements could be improved. Several teachers had questions about how to assess students' work. For example, if students are all doing something a little different, how can they be fairly assessed? Also, how can the assessment be made so that it doesn't constrain the students, yet at the same time indicates whether or not they've learned important skills and ideas? Do (and how do) challenge based lessons help traditional content learning and performance on conventional assessments? And finally, while a lot of CBL is about making connections to real life, how can a teacher know whether students are in fact making those connections?

Some teachers wondered about how to promote deeper research skills for students, including how "to make sure all students are coming back to all the core science ideas [after their research]" and "to make sure through their process of research there's a depth of understanding." 


\section{Section 3. Deeper Learning Opportunities and Outcomes in Challenge Based Lessons}

In this section, we discuss evidence on deeper learning opportunities and outcomes afforded by the challenge based science lessons. The discussion centers primarily around an analysis of 71 samples of middle school science lessons and associated student work. Two kinds of lessons were collected in addition to the challenge based lessons. This was a "typical" lesson that teachers characterized as representative of what students usually do in their classes. The second type of comparison lesson was selected by teachers to represent something they had done in their class that they thought was relatively well-aligned with at least one of the NGSS science and engineering practices ("NGSS practices-aligned"). Most of these comparison lessons were collected during the baseline visit before the project started, although some were collected later. Table 4 describes the three types of lessons we examined and compared.

Table 4. Three Types of Lessons the Project Collected and Examined

\begin{tabular}{|l|l|}
\hline Lesson Type & Description \\
\hline Typical & $\begin{array}{l}\text { Lessons that teachers reported as being typical. } \\
\text { Many lessons involved students obtaining } \\
\text { information from textbooks or online sources, } \\
\text { and/or applying terms to demonstrate } \\
\text { their knowledge. }\end{array}$ \\
\hline NGSS Practices-Aligned & $\begin{array}{l}\text { Lessons that teachers reported as being relatively } \\
\text { well-aligned with at least one of the NGSS } \\
\text { science and engineering practices, or if they were } \\
\text { not familiar with these, science inquiry. Most } \\
\text { lessons were either guided labs, inquiry labs (i.e., } \\
\text { labs where students had to figure out some of } \\
\text { the process), or lessons where students needed } \\
\text { to engineer solutions. }\end{array}$ \\
\hline Challenge Based & $\begin{array}{l}\text { Lessons that teachers created through } \\
\text { this project. Lessons included guided labs, } \\
\text { researching and designing solutions, simulations, } \\
\text { dissections, data collection, and analysis. }\end{array}$ \\
\hline
\end{tabular}


To identify whether lessons exhibited deeper learning opportunities and outcomes, the research team designed rubrics that were used to score the lessons and student work. The rubric dimensions represented learning domains that we identified as important to middle school science teaching and learning, based on the literature as well as project site visits and teacher input. Table 5 provides the set of dimensions for lessons and student work.

Table 5. Middle School Science Deeper Learning Dimensions Examined in this Report

\begin{tabular}{|c|c|}
\hline Learning opportunity dimensions & Student work dimensions \\
\hline $\begin{array}{l}\text { Activity calls for students to... } \\
\text { - engage with real-world phenomena or problems } \\
\text { that connect with their interests and values } \\
\text { - guide their own learning of science or } \\
\text { engineering } \\
\text { - discover principles or effective designs through } \\
\text { direct experience } \\
\text { - critically research existing information } \\
\text { - collaborate substantively } \\
\text { - effectively organize, style, and format } \\
\text { their communication }\end{array}$ & $\begin{array}{l}\text { Student(s) ... } \\
\text { - did/created something valuable to others as } \\
\text { part of their learning } \\
\text { - learned through practicing science } \\
\text { - made sound use of the three major stages } \\
\text { of the engineering design process } \\
\text { - critically researched existing information } \\
\text { - produced a product with effective } \\
\text { organization, style, and format }\end{array}$ \\
\hline
\end{tabular}

The rubrics went through a multi-stage development process described in detail in Iwatani, Vang, Romero, and Means (forthcoming). Care was taken to attend only to deeper learning factors that are closely related to science learning, and to align expectations with NGSS when possible. The goal was for the rubrics to capture skills and dispositions that teachers would regard as being central to their science instruction, rather than auxiliary or additional. Each dimension had five levels (0-4) where generally, 0 indicated absence of the deeper learning opportunity or outcome, 1 indicated emergence, 2 indicated partial presence, 3 indicated solid presence, and 4 indicated a presence that was above what might be expected of middle school learning opportunities and outcomes. Examples are provided in Tables 6 and 7 , while the full set of rubrics is provided in Appendices B and C.

In the summer of 2019, four science teachers and two education researchers used the rubrics to score 71 lessons and associated pieces of student work. Each lesson had up to two pieces of student work produced in response to the lesson. To support comparing "apples-to-apples," every piece of student work examined was what teachers considered at or above expectations for the assignment. In other words, student work that was clearly of low quality or incomplete was treated as ineligible for this analysis. Almost all lessons and more than 90 percent of the student work samples were scored by at least two scorers, with more than two-thirds of the artifacts scored by three or more scorer. Scorers had no knowledge of the project goals or research questions, and were not told which lessons 
were challenge based, typical or practices aligned. Each scorer scored their assigned lessons on the six deeper learning opportunity dimensions and five deeper learning student work dimensions (listed above in Table 5). In addition, the scorers provided their assessment on how well each lesson provided opportunities for students to understand grade-appropriate core ideas in science and/or engineering per the NGSS, and how much the student work demonstrated a sound understanding of these disciplinary core ideas (also based on the 0-4 point scale, as described further in Appendix D). As a group, the scorers were very consistent in their scoring using the deeper learning rubrics, and moderately consistent in their assessments concerning disciplinary core idea learning opportunities and demonstration.

This section presents the average scores of each deeper learning opportunity and student outcome (as seen through student work) dimension across different lessons in a lesson type. Appendix A provides more details on the scoring and analysis process, including information about score reliability. 
Activity Dimension 1: Activity calls for students to engage with real-world phenomena* or problems that connect with their interests and values.

\begin{tabular}{|c|c|c|c|c|}
\hline 0 & 1 & 2 & 3 & 4 \\
\hline $\begin{array}{l}\text { Activity } \\
\text { doesn't involve } \\
\text { real-world } \\
\text { phenomena or } \\
\text { problems (e.g., } \\
\text { it asks students } \\
\text { to learn facts } \\
\text { or a theory in a } \\
\text { decontextualized } \\
\text { way). }\end{array}$ & $\begin{array}{l}\text { Activity involves } \\
\text { a real-world } \\
\text { phenomenon } \\
\text { and/or problem. } \\
\text { Activity doesn't } \\
\text { call for students } \\
\text { to invest much } \\
\text { time, emotion, } \\
\text { or thinking } \\
\text { towards the } \\
\text { phenomenon } \\
\text { or problem. }\end{array}$ & $\begin{array}{l}\text { Activity involves } \\
\text { a real-world } \\
\text { phenomenon } \\
\text { and/or problem. } \\
\text { Activity calls } \\
\text { for students to } \\
\text { invest time and } \\
\text { thinking towards } \\
\text { the phenomenon } \\
\text { or problem. } \\
\text { Activity doesn't } \\
\text { attempt to } \\
\text { engage students } \\
\text { emotionally. }\end{array}$ & $\begin{array}{l}\text { Activity involves } \\
\text { a real-world } \\
\text { phenomenon } \\
\text { and/or problem. } \\
\text { Activity calls for } \\
\text { students to invest } \\
\text { time and thinking } \\
\text { towards the } \\
\text { phenomenon or } \\
\text { problem. } \\
\text { Activity attempts } \\
\text { to engage } \\
\text { students } \\
\text { emotionally by } \\
\text { connecting with } \\
\text { their interests } \\
\text { and values. }\end{array}$ & $\begin{array}{l}\text { Activity involves } \\
\text { a real-world } \\
\text { phenomenon } \\
\text { and/or problem. } \\
\text { Activity calls for } \\
\text { students to invest } \\
\text { time and thinking } \\
\text { towards the } \\
\text { phenomenon or } \\
\text { problem. } \\
\text { Activity attempts } \\
\text { to engage } \\
\text { students } \\
\text { emotionally, by } \\
\text { connecting with } \\
\text { their interests } \\
\text { and values. } \\
\text { Learning about } \\
\text { this topic can } \\
\text { greatly expand } \\
\text { students' } \\
\text { awareness and } \\
\text { change the way } \\
\text { they think, feel, } \\
\text { or act. }\end{array}$ \\
\hline $\begin{array}{l}\text { Examples: } \\
\text { Worksheet on } \\
\text { Punnett squares. } \\
\text { Demonstration of } \\
\text { evaporation and } \\
\text { condensation } \\
\text { of water. }\end{array}$ & $\begin{array}{l}\text { Examples: } \\
\text { Reading or } \\
\text { watching a video } \\
\text { about the impact } \\
\text { of deforestation } \\
\text { and answering } \\
\text { questions. }\end{array}$ & $\begin{array}{l}\text { Examples: } \\
\text { Designing the } \\
\text { tallest building } \\
\text { possible. } \\
\text { Investigating } \\
\text { how finches } \\
\text { have evolved } \\
\text { over time. }\end{array}$ & $\begin{array}{l}\text { Examples: } \\
\text { Designing a more } \\
\text { effective layout } \\
\text { for the school } \\
\text { cafeteria. } \\
\text { Investigating } \\
\text { the nutritional } \\
\text { content in chips } \\
\text { vs vegetables. }\end{array}$ & $\begin{array}{l}\text { Examples: } \\
\text { Designing a more } \\
\text { effective home } \\
\text { layout for a local } \\
\text { resident who is } \\
\text { paraplegic. } \\
\text { Investigating } \\
\text { the nutritional } \\
\text { content in food } \\
\text { that students } \\
\text { want to learn } \\
\text { more about. }\end{array}$ \\
\hline
\end{tabular}

*Note: "Phenomena are observable events in nature (or our lives) that connect to multiple NGSS disciplinary core ideas, such as Finnish Snow Trees or the behavior of bees" (Maltese, n.d.). 
Table 7. Example of a Student Work Rubric Dimension (full set provided in Appendix C)

Student Work Dimension 1: Student(s) did/created something potentially valuable to others as part of their learning.

\begin{tabular}{|c|c|c|c|c|c|}
\hline N/A & 0 & 1 & 2 & 3 & 4 \\
\hline $\begin{array}{l}\text { Assignment } \\
\text { didn't } \\
\text { ask for } \\
\text { student(s) } \\
\text { to create } \\
\text { something. }\end{array}$ & $\begin{array}{l}\text { Student } \\
\text { product is } \\
\text { missing, } \\
\text { incomplete, } \\
\text { and/or } \\
\text { misses } \\
\text { the point. }\end{array}$ & $\begin{array}{l}\text { A product } \\
\text { was created, } \\
\text { but its } \\
\text { interest/ } \\
\text { value to } \\
\text { others is } \\
\text { questionable } \\
\text { (e.g., purpose } \\
\text { is unclear } \\
\text { or not } \\
\text { compelling). }\end{array}$ & $\begin{array}{l}\text { Student } \\
\text { did/created } \\
\text { something } \\
\text { that could be } \\
\text { of interest/ } \\
\text { value to } \\
\text { others. } \\
\text { But the } \\
\text { product } \\
\text { is not } \\
\text { particularly } \\
\text { original or } \\
\text { creative. } \\
\text { It mainly } \\
\text { repurposes } \\
\text { already } \\
\text { available } \\
\text { information in } \\
\text { a simple way. }\end{array}$ & $\begin{array}{l}\text { Student did/ } \\
\text { created } \\
\text { something } \\
\text { that could be } \\
\text { of interest/ } \\
\text { value to } \\
\text { others. } \\
\text { The student's } \\
\text { work is } \\
\text { original } \\
\text { or creative. }\end{array}$ & $\begin{array}{l}\text { Student did/ } \\
\text { created } \\
\text { something } \\
\text { that could be } \\
\text { of interest/ } \\
\text { value to } \\
\text { others. } \\
\text { The student's } \\
\text { work is } \\
\text { original or } \\
\text { creative. } \\
\text { In addition, } \\
\text { student } \\
\text { provided } \\
\text { evidence that } \\
\text { either (1) they } \\
\text { thoughtfully } \\
\text { reflected on } \\
\text { strengths and } \\
\text { weaknesses } \\
\text { of their } \\
\text { design and/ } \\
\text { or (2) their } \\
\text { product was } \\
\text { appreciated } \\
\text { by others. }\end{array}$ \\
\hline Examples: & Examples: & Examples: & Examples: & Examples: & Examples: \\
\hline $\begin{array}{l}\text { Notes, } \\
\text { guided labs. }\end{array}$ & $\begin{array}{l}\text { A poster } \\
\text { about } \\
\text { weather, } \\
\text { when the } \\
\text { assignment } \\
\text { was about } \\
\text { genetics. }\end{array}$ & $\begin{array}{l}\text { A poster that } \\
\text { shows the } \\
\text { stages of } \\
\text { mitosis. } \\
\text { A word } \\
\text { search that } \\
\text { contains } \\
\text { genetics } \\
\text { terms. }\end{array}$ & $\begin{array}{l}\text { Educational } \\
\text { game or } \\
\text { poster } \\
\text { that raises } \\
\text { awareness } \\
\text { about } \\
\text { genetically } \\
\text { modified } \\
\text { foods. }\end{array}$ & $\begin{array}{l}\text { A prototype } \\
\text { of an app } \\
\text { that supports } \\
\text { parents with } \\
\text { a genetic } \\
\text { mutation } \\
\text { making } \\
\text { decisions } \\
\text { about having } \\
\text { a child. }\end{array}$ & $\begin{array}{l}\text { The app } \\
\text { (mentioned } \\
\text { to the left), } \\
\text { with a letter of } \\
\text { support from } \\
\text { a user, and/ } \\
\text { or a written } \\
\text { reflection on } \\
\text { strengths and } \\
\text { weaknesses of } \\
\text { the product. }\end{array}$ \\
\hline
\end{tabular}




\section{Challenge based science lessons provided more deeper learning opportunities than "typical" science lessons did. However, there is still room for the lessons to improve.}

Figure 4 compares the average deeper learning scores across all challenge based science lessons $(n=39)^{3}$ with those of typical science lessons $(n=17)$. The results are highly encouraging with respect to the potential for challenge based science lessons to provide deeper learning opportunities to students. On average, challenge based science lessons provided substantially more opportunities for: real-world engagement, self-direction, practice of science and engineering skills, conducting critical research, substantive collaboration, and effective communication. Moreover, challenge based lessons did this while being just as strong as typical lessons in terms of providing opportunity to learn grade-appropriate science content. ${ }^{4}$ Hedges' $\mathrm{g}$, a measure of how large the average score differences are in terms of standard deviation units, ranged from 0.88 to 1.75 for the difference between challenge based and typical lessons on the various deeper learning rubrics in our analysis. This suggests that the deeper learning scores of the challenge based science lessons were not just higher, but very much higher on average than scores of typical lessons.

However, these results also indicate that there is room for improvement in the challenge based lessons, especially in increasing opportunities for students to practice science investigations and engineering design, and to conduct secondary research more critically. Corroborating what the research team observed through classroom visits, the independent scorers who examined the challenge based lessons found that the deeper learning opportunities in these two areas, while stronger than the opportunities in typical lessons, were still just "emerging" (i.e., a score of approximately 1). So while challenge based lessons designed in this project provided significantly "more" opportunities than did typical lessons (that on average scored approximately 0 or a little over), the challenge based science lessons can improve much more on this front.

\footnotetext{
${ }^{3}$ This number is larger than the number of CBL units that were developed through this project because some CBL challenges consisted of multiple lessons (e.g., the cell phone jail challenge comprised a lesson where students did research on the nature of cell phone radiation, and another lesson where students designed a device that blocks them). Also, if some lessons were implemented differently across classrooms (even if they were triggered by the same CBL challenge), they were considered to be different lessons (e.g., one implementation of the cell phone jail challenge asked students to build and test a device, while in another, students were asked to draw a blueprint). These were considered to be "different" lessons because they were substantively different in what students were asked to do.

${ }^{4}$ The mean scores on science content were 2.03, 2.30, and 2.36 for typical, practices-aligned and challenge based lessons, respectively. There was no statistically significant difference between these scores (Appendix A, Tables A1 and A2).
} 


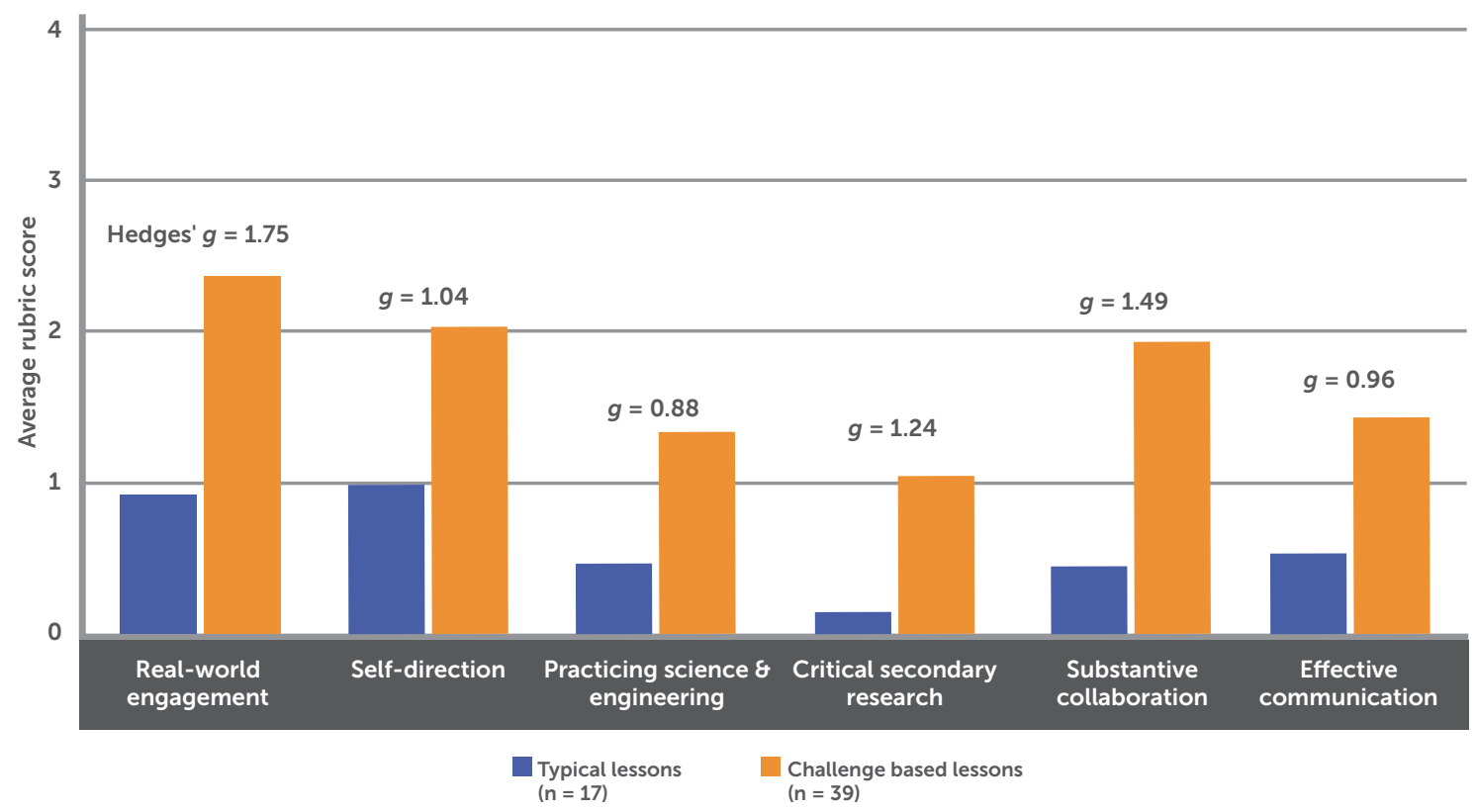

Note: All differences displayed are statistically significant $(p<.05)$. See Appendix A, Table A1, A2, and A3a for relevant data tables.

We also compared deeper learning opportunities provided by the challenge based science lessons to those in lessons that teachers provided as examples of "NGSS practices-aligned" (Figure 5). The latter lessons were not typical of what teachers usually did in class but did represent what they regarded as their best approximation of the kind of teaching called for in the NGSS. On average, the challenge based lesson scores were no different than those of NGSS practices-aligned lessons in three of the six deeper learning dimensions: self-direction, practicing science and engineering, and substantive collaboration. However, the challenge based learning lessons scored significantly higher than the NGSS practices-aligned lessons in the remaining three areas: real-world engagement, critical secondary research, and effective communication. 


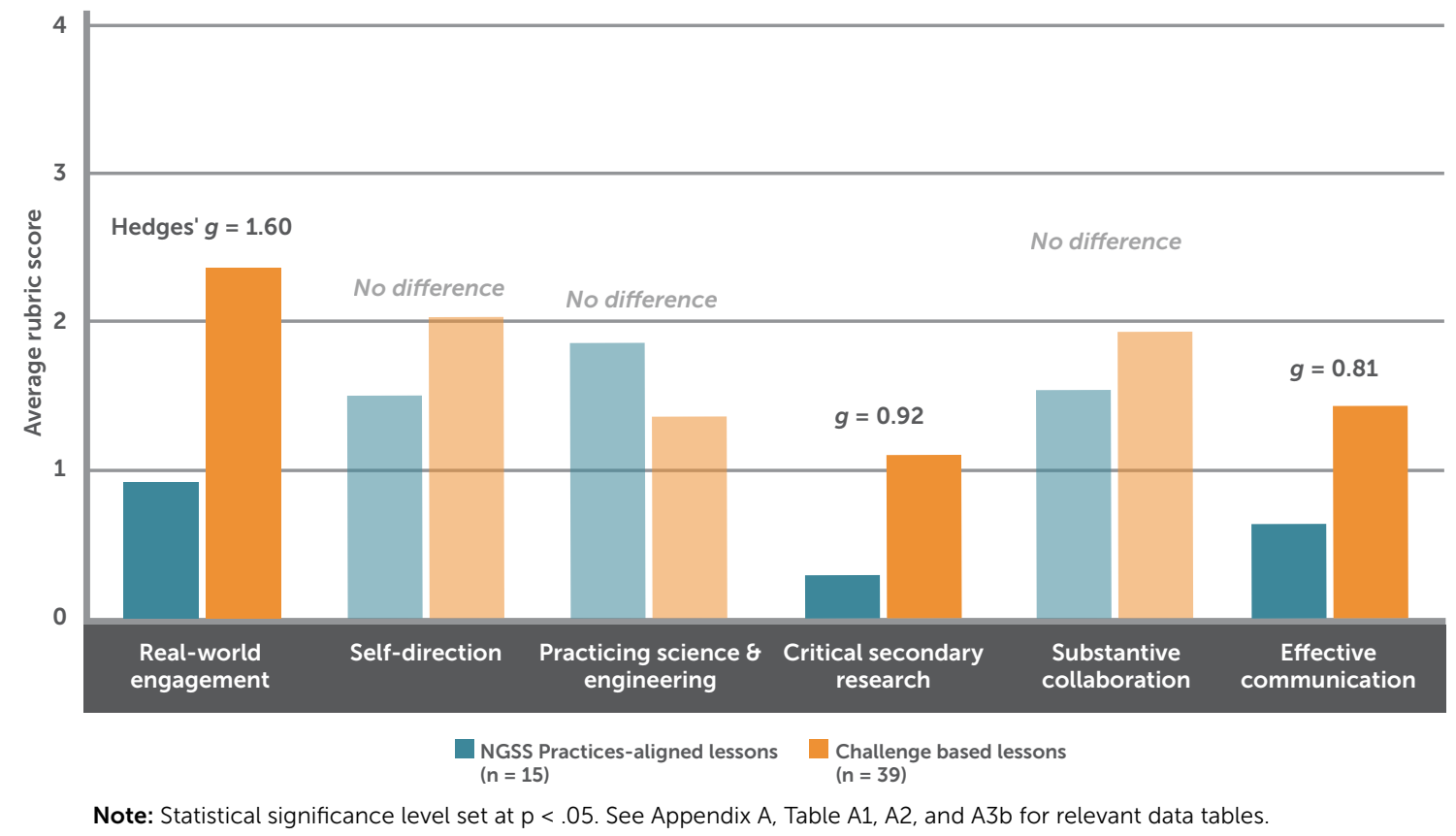

\section{When students in diverse classrooms are provided with opportunities to learn more deeply, they seem to do so}

Did students learn more deeply when provided with deeper learning opportunities? To address this question, we examined the student work produced in response to lessons with high and low scores on deeper learning opportunities. For example, if a lesson called for students to do critical research, we would expect the student work to demonstrate that students have applied critical research skills. Conversely, if students were not asked to strive to communicate their science ideas effectively, we would not expect students' work to demonstrate strong communication skills (though some students might naturally be good communicators or have learned communication skills through other classes).

We found that, as logic would suggest, students' deeper learning outcomes are positively and strongly correlated with opportunities to learn deeply (Table 8). For example, the more opportunities a learning activity provided for students to conduct science and engineering practices, the more evidence was found of science and engineering design competencies in students' work. 
Table 8. Correlation Between Deeper Learning Opportunities and Student Outcomes

\begin{tabular}{|l|l|l|}
\hline Learning Opportunity & $\begin{array}{l}\text { Student Outcomes (as seen } \\
\text { in work) }\end{array}$ & Correlation* \\
\hline A1. Real-world relevance & $\begin{array}{l}\text { S1. Did something relevant (of } \\
\text { interest/value to others) }\end{array}$ & .60 \\
\hline $\begin{array}{l}\text { A3. Conduct science/ } \\
\text { engineering practices }\end{array}$ & $\begin{array}{l}\text { S2. Practiced science } \\
\text { S3. Used engineering design }\end{array}$ & .63 \\
\hline $\begin{array}{l}\text { A4. Conduct critical secondary } \\
\text { research }\end{array}$ & $\begin{array}{l}\text { S4. Conducted critical } \\
\text { secondary research }\end{array}$ & .69 \\
\hline A6. Communicate effectively & S5. Communicated effectively & .69 \\
\hline $\begin{array}{l}\text { Understand disciplinary core } \\
\text { ideas }\end{array}$ & $\begin{array}{l}\text { Understood disciplinary core } \\
\text { ideas }\end{array}$ & .47 \\
\hline
\end{tabular}

* Polychoric correlation using bootstrap estimation. All correlations were greater than $0(p<.001)$.

\section{When participating in challenge based science lessons, students did more critical secondary research and real-world learning}

We saw earlier that CBL lessons provided deeper learning opportunities to a greater extent than typical and NGSS practices-aligned lessons did on several dimensions. Did these differences correspond to differences in deeper learning outcomes for students? Figures 6 and 7 show how student work scores for challenge based lessons compared to those for typical lessons and NGSS practices-aligned lessons, respectively. The data suggest that students were more likely to have done something that could be of interest/value to others (e.g., the community or society), and were more likely to have conducted critical secondary research through the challenge based lessons, relative to both typical and NGSS practices-aligned lessons. In addition, in the challenge based lessons, relative to the practices-aligned lessons, students were less likely to have used NGSS science practices but more likely to have communicated effectively (see Figure 7).

These results are not surprising; they corroborate teachers', students', and researchers' reports that in challenge based lessons, students engaged more with the real-world, did more secondary research, and communicated more often and more effectively. The student work scores generally did not reach the higher levels of the rubric in part because, as we saw above, most lessons did not call for students to reach the highest levels. This is understandable, especially when students are still inexperienced in guiding their own learning (as was the case with the great majority of students in this project). 
Figure 6. Challenge Based Science Student Outcomes Compared to "Typical" Science Student Outcomes

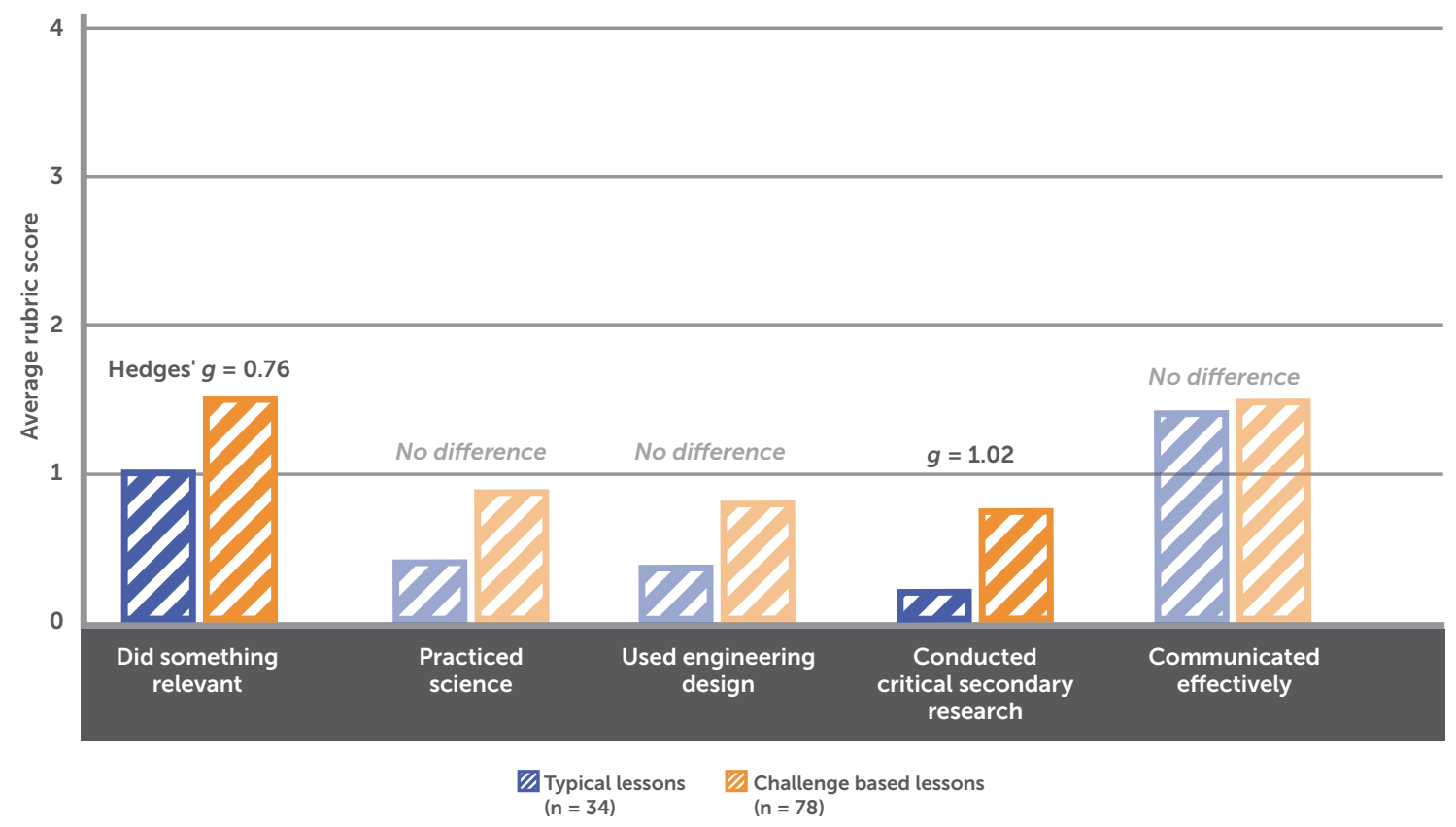

Note: Statistical significance level set at $p<.05$. See Appendix A, Table A4, A5, and A6a for relevant data tables.

Figure 7. Challenge Based Science Student Outcomes Compared to "NGSS Practices-Aligned" Science Student Outcomes

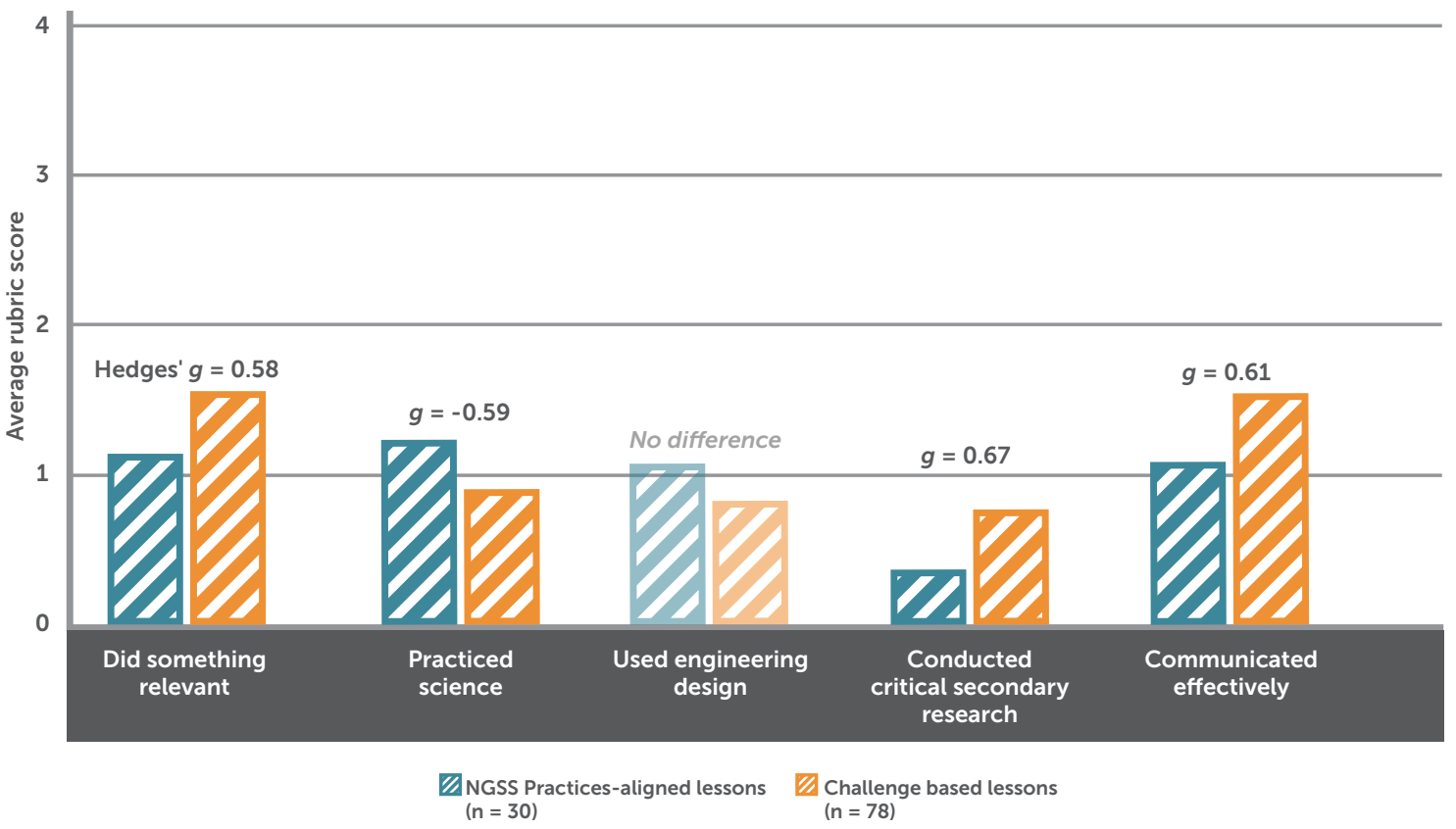

Note: Statistical significance level set at $\mathrm{p}<.05$. See Appendix A, Table A4, A5, and A6b for relevant data tables. 


\section{Exploration of factors potentially influencing the quality of deeper learning opportunities in challenge based science lessons}

We conducted exploratory analyses of several variables that could be expected to produce variation in deeper learning rubric scores. First, we examined descriptive statistics and conducted an analysis of variance on the overall score to determine whether the challenge based lessons produced and implemented after the first teacher workshop differed significantly from those produced after the second teacher workshop. We found that there was no significant difference between the first and second rounds of challenge based lessons, and that the variance was between challenge based and comparison lessons. Next we contrasted deeper learning ratings for the lessons developed by teachers in Title I schools $(n=8)$ versus those in non-Title I schools $(n=10)$. Again, the differences were not statistically significant (see Appendix A, Tables A7, A8, and A11). This suggests that challenge based science lessons provided comparable deeper learning opportunities across the two types of schools. It should be noted, however, that the relatively small size of the lesson subsamples limited our power to detect differences through these exploratory analyses. 


\section{Section 4. Lessons for the Field}

This section summarizes lessons learned and advice from teachers and students to education practitioners and the field of teacher education more generally. In addition, we summarize insights from the Digital Promise research team.

\section{Advice From Teachers}

\section{Letting go of control is hard, but well worth it.}

After creating and implementing challenge based science lessons, many of the project teachers said their key takeaway was that it was difficult, yet worthwhile, to provide students with some control over their learning. One shared that despite her initial worry, "It's okay to give them full rein, and in regards to the learning process, [allow students] to come up with their own questions and researching and creating." Others similarly said their main advice or takeaway was that teachers need to "learn how to let go," "be able to let go of the reins," "allow for student discovery," or "don't always have to be the one presenting."

Many teachers felt that providing students with opportunities to direct their own learning was rewarding because it gets all students in the class to participate in a deeper and more personal way (see Boxes 1 and 2 for examples). Several teachers reported anecdotes about how they were pleasantly surprised to see students who had been disengaged in class throughout the school year actively participate in their challenge based lessons. Some teachers also noticed that their higher-achieving students were challenged in a new and important way, as they needed to figure things out for themselves rather than memorize facts and procedures. Letting students work on their own projects turned out to be quite enjoyable for some teachers, allowing them to discover new aspects of students. As one teacher put it: "I just really like the fact that they get to kind of do their own thing ... it was kind of neat to see what they came up with."

Teachers from three of the five participating schools, all with lead roles in their schools' science curriculum, reported in their interviews that they now really understand the value of students trying to figure things out for themselves. One teacher shared how his understanding flipped, and that he now sees the hands-on exploration part as being where the student learning really needs to occur, rather than it serving as simply a "fun" phase that can be referenced in the future for (didactic) learning. Another teacher saw that even her top students were not able to transfer the concepts she thought they should have learned from all their labs and notes, so decided to take two additional class periods to have students solve a mini-challenge about earthquakes. "It takes longer [for them to figure it out on their own], but I think they learn better that way." Yet another teacher shared that her "ah-ha" moment was when her class seemed to intuitively derive the notion of "balanced force" after their exploratory investigation using helium balloons, even when she did not teach them any of the vocabulary in advance. The eighth-grade teacher concluded: 
I think a lot of teachers would say, "Well, why can't I just stand in front of the classroom and tell them what this is?" But I think walking away long term, they're going to keep that knowledge a little longer having had to figure that out themselves instead of me just dictate it to them.

\section{Box 1. An eighth-grade science teacher's reflection on} challenge based science learning

"It's definitely challenging to go outside the box of what you're used to doing. But I think it's rewarding. I think you see the light bulbs going off in your kids. You see that they're more engaged. ... [And because I did the lesson with all my class periods, rather than just my strongest], I saw a lot more of the kids that don't participate, or don't do anything. I did see a lot more of them kind of turning on a little bit. Even if they didn't complete the whole entire task, there were times and bits and pieces of where they were like, 'Oh, I'm going to do this part. I'm going to do this part of it.' ... And when you teach to a test like so many of us are doing, unfortunately, you start to see your kids in a different way. Some kids that you think are never going to do anything, they actually show you, you know, 'I am interested in science. I just don't like the way that we do it every day.' So I think it's kind of eye opening too when you see some of the kids in a different way when they're creating, and doing, and investigating, and researching on their own versus what you tell them to do. And worksheets and notes. So I think it gives you, like an insight to what they might be like outside of that. I think it's rewarding in that manner." (Eighth-grade veteran science teacher, after creating and implementing two challenge based science lessons)

\section{Box 2. A seventh-grade science teacher's reflection on challenge based science learning}

"You know, I reflected a lot on just my teaching. I learned more of the content. The teaching style was definitely different, for the better. I think it's something that can work in the future. Will I do it again? I definitely will do the [challenge based science] unit again, if I could get the standards for next year, because I know we're re-routing. But I would definitely do that again. I don't know. I felt that it ... I felt almost this type of learning does make the connection a little stronger with them. It allows me to sit with groups and move around a lot, where I'm not just up instructing. I did notice that-where I can move and sit. Like, I would just sit with groups and talk to them. There was more of an individual instruction piece as well. This type of instruction allows for that. It does. I felt like I had more time in that 80-minute block where I can meet with individual groups, whereas if I'm doing direct instruction I feel like I'm up there constantly and not able to meet. Whereas this time everyone's working, so I can scoot around for five or 10 minutes per group ... Yeah. That is true. That is true! Yeah. I didn't think about that until just now. That's true." (Seventh-grade veteran science teacher, after creating and implementing two challenge based science lessons) 


\section{Hardest part is the "engage" and facilitating student questioning, but practice helps.}

Teachers thought that getting students to "engage" in their challenge was difficult because it could be hard to find a topic that most students would like. It is also not easy to facilitate middle schoolers' varying opinions and thoughts in a productive direction. Middle school teachers receive training in many areas, but typically not in facilitative management and project supervision. So understandably, many teachers who were facilitating student questioning for the first time (more than three-quarters of the participating teachers) felt somewhat nervous about the process. Some worried about whether they could be quick enough on their feet to respond to unanticipated questions (especially when they were being observed by researchers!), and some about worried whether students could come up with questions, move towards a productive direction, or carry things out on their own. Despite such initial worries, teachers experienced success, often to their surprise:

I was most worried about organizing all the sticky notes [with individual student questions triggered by the phenomenon] and stuff and I'm not very good at somebody coming out saying something me just coming up with something real quick. You know, I'm not witty like that. I kind of have to think about things. And that sticky note totally puts you on the spot because you have no idea what they're going to ask, and I surprised myself just by going with it ... and being able to organize it. I was proud of myself...I learned when I am able to just, you know, spurt some things out without having to think about it. (Seventh-grade science teacher, after implementing first challenge based lesson)

Teachers who were nervous about facilitation agreed that it gets much easier with practice. It gets easier throughout the day and the second challenge based lesson was much easier than the first. One teacher shared: "My first period class, they get all my stumbles. And then by the time I go to the afternoon, it's a lot better."

\section{Even when students are in control, you can still guide where they're going.}

Participating teachers had reassuring advice for colleagues who might worry about maintaining classroom control when students drive their own learning. One veteran teacher said that it was very important for her and other teachers to learn that they "just have to go with the flow and lose control." But this doesn't mean letting students do whatever they want. She said if students go in a direction she likes, she can "go with it," and the learning is that much more powerful. Indeed, she was surprised that sometimes students came up with good ideas that she had not thought of. However, if she doesn't like where her students are going, she can (and should) redirect them the next day, and this is not such an onerous task. Similarly, other teachers used metaphors like wind and sailboat, or a stream and a canoe to describe their relationship with students during challenge based lessons. With students steering their learning, the teacher is like the wind or the stream that heavily influences the driver's direction, and on which the driver depends. Teachers used a variety of methods to guide students without being prescriptive, including highlighting student questions or comments that were particularly aligned with science, creating check-ins to 
catch students before they got too lost, and adding their own questions in ways that would nudge students towards more productive directions.

The ideal balance between student-directedness and teacher-directedness can be tricky to achieve and needs continuous refinement.

Teachers continuously wrestled with the balance of how much freedom to provide their students, and how much they should guide or scaffold. Should they specify what product students should make, and if so, how specifically? To what extent should they shape the questions students pursue or how much research they do? If the teacher keeps things open-ended, how should students be assessed? In some cases, keeping things open-ended worked much better than teachers expected. For example, one teacher provided fairly detailed guidelines for secondary research in some classes, asking students to fill in a worksheet that specified the number of questions and providing boxes where students would fill out answers to their questions. Seeing that this structure seemed to be constraining students, she switched her approach in her afternoon classes to ask students simply to research what they thought was important to know about the topic, without providing the worksheet. She was surprised that students in the afternoon classes seemed more engaged with the process and conducted more thorough research than did students in the morning classes.

On the other hand, teachers also observed that students needed some amount of structure, especially when they were new to identifying and solving big challenges. Many teachers found a balance by having some standard requirements. Examples of the requirements teachers set within challenge based learning units included requiring students to research a core set of questions in addition to their own, stipulating some investigation activities, and giving some specific requirements for final products.

\section{CBL units might be a sustainable alternative to adopting a full project-based learning model where everything has to be project based.}

Two of the participating teachers had much less to learn about student-centered instruction than the other teachers did because they were fully trained in project-based learning (PBL) and had been implementing it daily for several years. While challenge based learning didn't feel new to these teachers, they appreciated the learning curve that other teachers were experiencing. One commented that while her personal preference would be to go "full PBL," she understands that's neither the only way-nor necessarily the most appropriate way-to engage students, especially in schools with high staff turnover and limited resources. It takes many resources to train teachers to do PBL year-round, and not all teachers are comfortable with this pedagogy (which she believed to be "completely legitimate"). She'd also heard in PBL leadership trainings that it's unfortunately common for $\mathrm{PBL}$ schools to revert to "traditional" curriculum and instruction because of staff turnover and inability to maintain the required intensive professional development. She wondered whether incorporation of shorter-term CBL units, as teachers did in this project, might be a sustainable alternative to providing students with deeper thinking and inquiry opportunities, perhaps serving as a gateway experience leading to "full-on" PBL or CBL. 


\section{This was really hard. It would have helped to have examples.}

One teacher seemed to represent the voice of well over half of the teachers when she said that the professional learning experience was "really hard" because she had to learn so many new things, it took a lot of time, it was a lot of work, it pushed her out of her comfort zone, and everything was so "experimental." Including the time in project workshops, teachers devoted at least three days to developing each lesson, and some teachers spent additional time on their own. With no prior examples of CBL units aligned to the NGSS to work from, teachers had to rely largely on their imaginations, experience, and an evolving project lesson template. Some teams went through several major revisions of their CBL units before feeling they were ready to implement with students. While all participating teachers thought that their hard work was ultimately worthwhile (e.g., one teacher described her journey as "hesitant $\rightarrow$ frustrated $\rightarrow$ enlightened"), they also thought that teachers new to the process would be greatly helped by having strong examples of NGSSaligned CBL units.

\section{Advice From Students}

\section{Try to make the topics relevant to us.}

In focus groups, students frequently shared that they wanted their teachers to continue doing the challenge based science lessons, as they were fun, hands-on, and meaningful. When students weren't as enthusiastic about their challenge based science lesson (a small minority of students), they tended to say it was because the topic did not feel relevant to their own lives (e.g., "[Our impact on the environment] is not something your average seventh grader would be talking to their friends about"; "[Teachers should give us] more experiments, which is like going to help us in our real life. Like real, everyday life.")

Across all student focus groups, however, there was no strong consensus among students on what topics were interesting or relevant. Interestingly (given prevalent assumptions about middle schoolers' fascination with disaster), the CBL lessons on natural and human-made disasters tended to receive less enthusiastic comments than did engineering lessons. To researchers, it seemed that the specific topic didn't matter as much as what and how much students felt they learned from the unit. When students felt they learned a lot about things they didn't know before (e.g., about specific pollinators/species, antibiotic resistance, blue light), they tended to regard the topic as being extremely relevant and interesting. When students felt they already knew a lot about the topic (e.g., negative impacts of natural disasters; how humans are polluting the environment), they tended to describe those topics as important but not as interesting.

\section{It's hard if we don't have enough time to do our projects.}

Students had few negative things to say about the challenge based lessons they experienced, but several did express a wish for more time to focus on their final projects. They felt that the emphasis was on the earlier stages of investigating their challenge and there was too little time for their final project. In some lessons, students spent two to four days 
investigating and conducting research, then only one to two days on the "act" portion of CBL. This sometimes caused students, especially the higher-achieving students, to address the "challenge" in the easiest way they could get away with (e.g., making educational slideshows or quizzes that just summarized information they learned rather than building on it).

\section{It can get boring to just read stuff on the internet, to learn what we already (think we) know about, or to hear the same presentation over and over.}

While the challenge based science lessons attempted to engage students in ways different than their normal lessons, there were aspects that some students found boring or frustrating that impacted their experience. Some students found that many times they were just researching on the internet for answers related to their topic or for research to create their prototype. They preferred doing things that were "hands-on," like doing experiments and building things.

Another aspect that some students disliked was listening to many presentations on the same topic. Some teachers had students present what they learned from their research to the class, and students found that many of their peers were presenting the same findings since they all had similar questions. These are issues common in teachers' first attempts at $\mathrm{CBL}$ and could be addressed in the design of project flow and student grouping strategies for future challenge based learning units.

\section{Researcher Insights}

\section{Student-centered, standards-aligned science teaching requires many skills, so it is important to create rich learning ecosystems where these can be cultivated and devel- oped as needed.}

It is very difficult to teach middle school science in a student-centered way (whether through $\mathrm{CBL}$, PBL, or otherwise), and in ways aligned with NGSS. This is because such teaching requires teachers to have all of the following:

1. Reasonable familiarity with NGSS

2. Strong grasp of science content knowledge, science and engineering practices, and the nature of scientific investigation and engineering design

3. Comfort with the idea of student-centered learning

4. Awareness of students' role in the learning process, and ability to work with that

5. Strategies to facilitate student-centered learning, including facilitation skills and pacing

6. Having a bank of activities/lessons/investigations that facilitate student-centered learning (to draw upon for the "investigate" phase of $\mathrm{CBL}$ ) 
7. Experience with successfully implementing student-centered learning

8. Some immunity/resistance to pressures from testing

Each of these is difficult to achieve on its own, with the implication that "making student-centered learning happen" in a single classroom or school in a short amount of time is not realistic. A broader system of support appears to be needed. Indeed, this project's success seemed to rely heavily on teachers, district/school leaders, and Digital Promise staff coming together with a shared goal, along with combining their resources and talents. Figure 8 depicts assets that each of these groups brought to the project that were important for teachers to be able to create and implement the lessons as successfully and enthusiastically as they did.

Figure 8. What Teachers, District/School Leaders and Digital Promise Brought to the Table that Contributed to the Project's Success

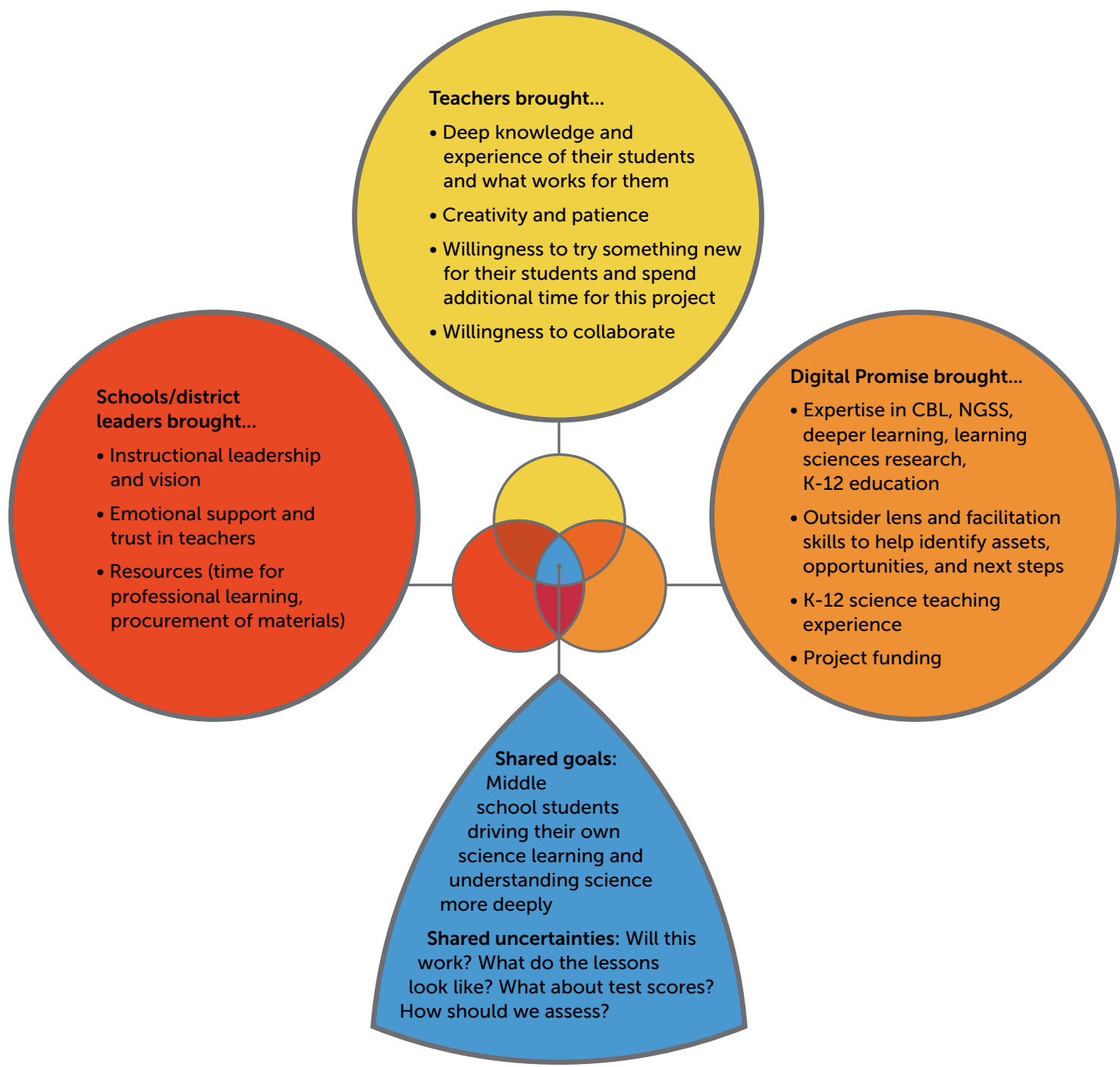


The combination of these assets led to the following conditions that research scholarship considers to be essential for transformative professional learning (Box 3).

\section{Building upon teachers' knowledge and expertise}

First, the professional development involved and relied upon teachers' extensive teaching experiences that allowed them to create lessons that worked well for their students and with their teaching style. Teachers were able to implement their collaboratively developed lesson designs with high fidelity. Teachers' collective knowledge and experience was also important in enabling them to clearly identify key takeaways for themselves as they tried new approaches throughout the school year.

\section{Professionally relevant, affective learning towards value-laden goals}

On a related point, the teachers' learning experiences were professionally relevant, and engaged teachers emotionally as well as cognitively. This engagement was fostered by teachers' identification with the values inherent in the project's focus on helping students identify and act on things that are important to them. The possibility of helping students in an emotionally compelling way seemed to motivate several teachers to try something new, even if they had initial doubts about the outcome.

The professional relevance came from the project deliberately focusing on goals that are important for middle school science teachers (deeper, self-directed learning in science), and-as best as possible-avoiding cramming in goals that are nice-to-have but ultimately less important (e.g., promoting a certain reading or collaboration strategy; requiring all lessons topics to be about local phenomena). The CBL framework encouraged teachers to provide students with greater substantive control over their own learning to a greater extent than called for in the NGSS. The NGSS, however, provided practices through which students could engage in authentic science learning, helping to narrow and define what students could choose to do with the agency that $C B L$ gave them. The combination of CBL and NGSS appeared to be fruitful.

\section{Intense and experiential learning}

Furthermore, the process through which teachers learned how to design and implement challenge based learning activities was intense and experiential. Teachers learned not from lectures and presentations of information, but from experiencing the CBL process as learners (which many teachers reported as being extremely helpful) and from getting student feedback when they tried out their first CBL activities.

\section{Continuous opportunities for critical reflection}

The project provided continuous and natural opportunities for critical reflection. Teachers reflected on their teaching and learning as they designed and implemented their two lessons. Release time for co-design supported teachers in having multiple conversations about their student learning and engagement with their colleagues, which many found to be extremely helpful. Digital Promise provided rich opportunities for critical reflection and 
dialogue through the design workshops and research interviews. The program's focus on CBL focused the discussions and reflections around student engagement and student-centered learning.

\section{Authentic relationships}

Finally, authentic relationships were forged among all parties involved (teachers, school/ district leaders, and Digital Promise). Teachers got to know one another better, especially if they worked on the same lesson. District and school leaders supported teachers' risk-taking in a number of important ways, including finding release time and resources, expressing support and appreciation, and providing instructional leadership. Some leaders rolled up their sleeves and worked on creating a CBL lesson right alongside their teacher teams. Teachers reported that these concrete expressions of support from their leaders were essential to their willingness to move outside of their comfort zone. Leaders likewise reported appreciating their teachers' dedication and willingness to do something new and different to support their students and district. Digital Promise also came to understand and appreciate each teacher's and school's interests and strengths, which helped shape the professional learning and research activities as the project matured.

\section{Box 3. What makes learning transformative for adults?}

Some learning experiences can be extremely impactful, such as in cultural exchange programs where people with very different values and beliefs learn deeply from one another, or when medical students get to know patients and families under palliative care. Adult learning scholars have conceptualized such "transformative" learning experiences in a number of ways, thinking about it as:

- Large shifts in learners' cognitive assumptions (e.g., Mezirow, 2000);

- Increased integration of one's inner and outer worlds (e.g., Dirkx, 2012);

- Gaining new ways to see and know the world (e.g., Kagan, 2000); or

- Becoming empowered with the critical consciousness needed to identify and act against structures of oppression (Freire, 1970/2018).

After closely reviewing more than 200 studies on transformative learning, Hoggan (2016) defined it as "processes that result in significant and irreversible changes in the way a person experiences, conceptualizes, and interacts with the world" (p. 71). 
While there may be many ways for learning to be transformative, there is broad consensus on the characteristics of learning experiences that tend to facilitate powerful shifts in learners' views, experiences, and interactions in the world (Taylor, 2006). The characteristics are interrelated and mutually reinforcing. The first is rich individual experiences, which include experiences in the classroom as well as life experiences that learners bring to the classroom. Learning experiences tend to be more transformative if the content is value-laden, the activities are intense and experiential, and the participants have greater life experience from which to draw and react to the new experience.

Critical reflection is another important feature. Learning is more likely to be impactful if learners reflect on what and how they're learning, and perhaps most importantly gain insight on why they learned or realized something they hadn't before (Mezirow, 1991; 2000). This type of reflection is facilitated through engagement in dialogue with themselves and others. The nature of dialogue that best facilitates insight and change in values and behaviors is not overly critical or analytical, but rather one of a supportive and personal nature. Through dialogue, learners can grapple with making sense of what they see and feel, and gain feedback and affirmation for changing their beliefs, actions, or values. As such, the learning experience should have a holistic orientation to teaching, which refers to incorporation of ways of knowing besides the rational "analyze-think-change". In particular, affective learning, which utilizes a "see-feel-change" sequence, has been considered an important and much more effective facilitator of change than a purely rational sequence (Brown, 2006).

Perhaps not surprisingly then, facilitators who hope for shifts in learners' core beliefs, values and behaviors, should be aware of the contexts in which learners operate, and forge authentic relationships with them. We tend to form beliefs, values and behaviors to help us survive in our world. If someone requests that we relinquish some of our time-tested survival strategies but either does not seem to care about our well-being or has no understanding of our environment and needs, why would we listen? 


\section{Section 5. Next Steps}

We have shared evidence that the challenge based science learning project led teachers to try dramatically student-centered science instruction, which increased deeper learning opportunities for middle school students and led to measurable improvements in key aspects of student work. Where does all of this leave us? What are productive next steps towards great science learning for middle school students? In this final section of the report, we derive implications from our work for current practice and for future avenues of research and development.

\section{What are the implications for the design of professional learning activities for teachers?}

Although the science teachers in this project all came from districts that were implementing the Next Generation Science Standards (NGSS), only a few of them had a deep familiarity with the standards and understanding of the concept of "three-dimensional learning." Hence, the learning workshops had to support learning about the standards as well as learning about Challenge Based Learning (CBL) deeply enough to be able to represent both in original designs for student learning activities.

As described in Section 4, the veteran teachers participating in this project viewed the professional learning activities as very challenging, but at the same time extremely worthwhile. The professional learning activities embodied the qualities of effective teacher professional development identified in research literature (Darling-Hammond, Hyler, \& Gardner, 2017). They were of sustained duration, occurring over an eight-month period and involving more than four days of in-person workshops, at least two additional days of lesson co-design time, 10 days of implementation, and many additional hours of reflections (on their own, with colleagues, and with the instructional design facilitator and researcher) about how the lessons went. The professional learning activities were content focused, customized to the Next Generation Science Standards rather than presenting CBL in a domain-agnostic way. They emphasized active learning, with the vast majority of time spent in co-design activities rather than in receiving information. Professional learning was structured as a collaboration in a work context, with teachers designing with other teachers from their school or district. It featured modeling of the target practice, with the training facilitator using CBL phases and moves to impart NGSS-related concepts. The instructional design facilitator, the project researcher, and district/school leaders (in several districts) provided coaching and expert support. Finally, the two rounds of lesson design with implementation in between were structured intentionally to provide for feedback and reflection.

In addition to incorporating these widely acknowledged best practices, the professional learning in this project appeared to benefit from several additional features. The professional learning called for teachers to make a dramatic change in their instructional approach, but only as a "try it" for a relatively brief period of time (first a lesson of a few days and then one of approximately one week). This approach made the change low risk compared to adopting an entirely new curriculum or new way of teaching for the entire year. Risk was 
further reduced by having the effort endorsed by administrators in their own districts who assured teachers that they would be held harmless with respect to any district prescriptions around methods or accountability requirements in tension with the CBL units. Teacher learning in this project also benefited also from an alignment of values: CBL's emphasis on engaging students' hearts and minds appeared to resonate strongly with participating teachers. Finally, sustained involvement in this project's teacher learning activities was motivated by visible results: The student response to $C B L$ activities was so positive that their teachers were motivated to learn and do more.

\section{How can the challenge based science lessons developed through this project be made stronger, with deeper learning opportunities and outcomes for students?}

The challenge based activities that teachers designed and developed through this project were consistently superior to teachers' typical science lessons in terms of inviting the aspects of deeper learning embodied in our learning activity rubrics. On some of the dimensions, the challenge based lessons even exceeded the lessons the teachers regarded as those best-aligned to NGSS practices. But that is not to say that teachers' first attempts at designing NGSS-aligned, challenge based learning activities were completely successful. In terms of rubric levels, most of the CBL lessons provided some opportunities for deeper learning but fell short of the top rating of fully realized opportunities to acquire deeper learning competencies. This result is not unexpected. Teachers need time and ample practice opportunities to learn how to create high-quality, student-centered activities around scientific phenomena and investigations. The joint design activities and feedback from other teachers built into this project gave teachers the confidence to try something new, but a stronger set of supports could be provided. Teachers wanted examples of strong, NGSS-aligned, challenge based learning activities, and we are only now at a place where we can provide examples of activities at different levels of quality on the rubrics. Further scaffolding of teachers' activity design work could be provided by having a set of templates that build in NGSS practices and the phases of CBL while allowing for customization to individual teachers' curriculum, interests, or local context. (This idea will be explored further below.)

The influence of the teacher co-design activities on the quality of student work was more modest than that on the nature of the enacted science learning activities. This is to be expected since the professional learning activities affected the resulting CBL unit designs directly while the influence on student work was indirect (mediated by the CBL units). To obtain larger, more consistent impacts on student work, we would want to have students exposed to a series of challenge based science learning activities in a sequence that builds up students' understanding of what it means to pose a good question about a science phenomenon, how to design an investigation to address a question, the components of the engineering design process, and so on. Making CBL a larger part of science courses would be expected to increase student demonstration of the various dimensions of deeper learning. 


\section{What are the implications for scaling high-quality professional learning and NGSS- aligned challenge based learning?}

The collaborative design work with peers, instructional designers, and researchers in this project appeared to give science teachers a deeper understanding of both CBL and NGSS principles than typical teacher professional development would. But it consumed considerably more resources, with the main cost being teachers' cognitive and emotional efforts, including time they had to put in outside of their regular work day to develop these new lessons. The level of resources required for these learning activities will not be available for the majority of teachers in the majority of schools. Scaling up NGSS-aligned challenge based learning will require finding less costly ways to support teacher learning and consequential changes in practice.

The question is whether it would be possible to obtain comparably deep understanding of CBL and NGSS while also motivating teachers to do this kind of instruction, without requiring every teacher to participate in designing learning activities from scratch. In other words, to what extent was teacher creation of new learning activities a necessary component of this work? Would the same benefits result if teachers used the challenge based science units developed by others? Or would a "Goldilocks strategy" of medium-intensive professional development-teachers adapting existing NGSS-aligned, challenge based learning activities for their specific students while also piloting the modified units-provide the best results?

\section{How can OER support instructional transformation among K-12 teachers?}

While teachers in this project co-created a resource bank of existing open educational resources (OER) with Digital Promise staff and were given time to explore these resources, most created the resources needed for their CBL units from scratch and incorporated existing resources they obtained using general search engines rather than the OER resource bank. Participating teachers were not OER evangelists, and OER use was not the motivation for their activities. Nor were project teachers' districts placing a heavy emphasis on OER. The project's original expectation was that teachers' co-designed learning activities would become OER for others to use. Early in the project, though, we realized that an infrastructure-to provide quality assurance and coherence across the various learning activities-would be needed to make this realistic.

There is not an obvious pay-off for $\mathrm{K}-12$ teachers to use OER over other materials they can access freely and/or adopt through fair use. By implication, OER is more likely to be used in $\mathrm{K}-12$ settings when there is a district initiative to adopt OER as a textbook or whole curriculum replacement. OER is also not likely going to be a catalyst for radical improvement in K-12 instruction. In addition, OER "bits" are not likely to inspire teachers to change their practice in significant ways. However, in the context of a broader initiative around instructional improvement, we believe OER can play a supportive role. One area where we see promise is in having templates or "shells" for powerful learning activities in science (or another domain of focus). These can be in the public domain and designed in a way that 
makes adaptation to local circumstances and student interests easy to do. For example, a unit built around the challenge of providing a supply of potable water in situations with water contamination could offer a set of OER that allow teachers to choose and modify alternative contamination scenarios depending on their locale and their curriculum. Despite differences in surface features, all of the scenarios would use a common unit structure and feature parallel activities and assessments for science and engineering practices applied to investigating sources of contamination and testing alternative water purification strategies.

The feasibility of this idea of customizable OER learning activity templates could be tested in concert with investigating more cost-effective approaches to teacher professional learning, as described above. The level of teacher engagement, changes in teacher practice, and quality of student work could be contrasted for (1) teachers designing their own NGSS-aligned CBL units; (2) teachers using customizable OER templates for NGSS-aligned CBL units; and (3) teachers using NGSS-aligned CBL units designed by other teachers.

\section{Final Thoughts ...}

It is important to put the work described in this report in the broader context of science instruction in the United States. A recent survey of a nationally representative sample of science teachers indicated that despite national efforts to promote the Next Generation Science Standards, less than half of all middle school science teachers emphasize learning how to do science in their classrooms and less than 10 percent emphasize learning how to do engineering (Banilower et al., 2018). The reliance on teacher-directed transmission of science concepts to the neglect of other pedagogies and aspects of science is not going to change absent major systemic efforts and tools to support science pedagogies that few teachers have experienced themselves. Sporadic half-day professional development sessions are not going to be sufficient to bring about the needed transformation.

The experiences teachers had through this project were a major departure from typical teacher professional development in terms not only in terms of intensity, but also in terms of learner-centeredness. This characteristic was the main reason teachers found the experience so much more relevant than other professional development they had received. Just as the teachers were asking their students to rise to a challenge, the professional learning in this project asked teachers to rise to the challenge of designing and implementing student-centered science learning. While not all professional development can (or necessarily should) be so extended and participant centered, our intuition is that initiatives that encourage teachers to radically change their instruction to a more student-centered approach will always need a significant experiential component. Empirical testing is still needed to learn how much of these experiences will be sufficient for different kinds of teachers. 


\section{References}

Banilower, E. R., Smith, P. S., Malzahn, K. A., Plumley, C. L., Gordon, E. M., \& Hayes M. L. (2018). Report of the 2018 NSSME+. Chapel Hill, NC: Horizon Research.

Brown, K. (2006). Leadership and social justice and equity: Evaluating a transformative framework and andragogy. Educational Administration Quarterly, 42(5), 700-745.

Cator, K. \& Nichols, M. (2008). Challenge Based Learning white paper. Cupertino, CA: Apple, Inc. Retrieved from https://www.challengebasedlearning.org/wp-content/uploads/2019/03/ CBL_Paper_2008.pdf

Challenge Based Learning. (n.d.). San Mateo, CA: Digital Promise. Retrieved from https://cbl.digitalpromise.org/

Challenge Based Learning publications and research. (n.d.). San Mateo, CA: Digital Promise. Retrieved from https://www.challengebasedlearning.org/learn/research/

Challenge based science learning toolkit (2020). San Mateo, CA: Digital Promise. Retrieved from https://digitalpromise.org/initiative/next-generation-science/cbl-ngss/

Darling-Hammond, L., Hyler, M. E., \& Gardner, M. (2017). Effective teacher professional development. Palo Alto, CA: Learning Policy Institute.

Dirkx, J. M. (2012). Nurturing soul work: A Jungian approach to transformative learning. In E. Taylor \& P. Cranto (Eds.), The handbook of transformative learning: Theory, research, and practice (pp. 116-130). San Francisco, CA: Jossey-Bass.

Freire, P. (1970/2018). Pedagogy of the oppressed. New York, NY: Bloomsbury Academic.

Hewlett Foundation. (2013). Deeper learning competencies. Retrieved from https://hewlett.org/ wp-content/uploads/2016/08/Deeper_Learning_Defined__April_2013.pdf

Hewlett Foundation. (n.d.). Open educational resources. Retrieved December 12, 2019, from William and Flora Hewlett Foundation website https://hewlett.org/strategy/ open-educational-resources/

Hoggan, C. D. (2016). Transformative learning as a metatheory: Definition, criteria, and typology. Adult education quarterly, 66(1), 57-75.

Huttner, N., Green, L., \& Cowher, R. (2018). Seeking a sustainable OER ecosystem. Redstone Strategy Group.

Iwatani, E., Vang, M. C., Romero, M. R., \& Means B. (forthcoming). Rubric for assessing deeper learning opportunities and outcomes in middle school science classes and student work: Validity evidence technical report. San Mateo, CA: Digital Promise. 
Jordan, R. (2019, September 19). How administrators can support teachers to embrace new practices. Retrieved December 10, 2019, from Digital Promise website https://digitalpromise. org/2019/09/19/how-administrators-can-support-teachers-to-embrace-new-practices/

Kagan, R. (2000). What "form" transforms? A constructive-developmental approach to transformative learning. In J. Mezirow (Ed.), Learning as transformation: Critical perspectives on a theory in progress (pp. 35-70), San Francisco, CA: Jossey-Bass.

Krajcik, J. (n.d.). What is three-dimensional learning? Retrieved December 12, 2019, from Activate Learning website http://activatelearning.com/three-dimensional-learning/

Mezirow, J. (1991). Transformative dimensions of adult learning. San Francisco, CA: Jossey-Bass.

Mezirow, J., \& Associates. (2000). Learning as transformation: Critical perspectives on a theory in progress. San Francisco, CA: Jossey-Bass.

National Research Council. (2012). A framework for K-12 science education: Practices, crosscutting concepts, and core ideas. Committee on a Conceptual Framework for New K-12 Science Education Standards. Board on Science Education, Division of Behavioral and Social Sciences and Education. Washington DC: The National Academies Press.

Next Generation Science Standards. (2013, April). APPENDIX I - Engineering design in the NGSS. Retrieved from https://www.nextgenscience.org/sites/default/files/Appendix\%20l\%20-\%20 Engineering\%20Design\%20in\%20NGSS\%20-\%20FINAL_V2.pdf

Next Generation Science Standards. (2016). EQulP rubric for lessons \& units: Science. Retrieved December 12, 2019, from Next Generation Science Standards website https://www.nextgenscience.org/sites/default/files/EQulPRubricforSciencev3.pdf

NGSS Lead States. (2013). Next Generation Science Standards: For States, By States. Retrieved from http://www.nextgenscience.org/

Nichols, M., Cator, K., \& Torres. M. (2016). Challenge based learner user guide. Redwood City, CA: Digital Promise. Retrieved from https://www.challengebasedlearning.org/project/cbl-guide/

Taylor, E. W. (2009). Fostering transformative learning. Transformative learning in practice: Insights from community, workplace, and higher education, 3-17. 


\section{Appendix A. Methodological and Analysis Details}

\section{About the Project Participants and Setting}

Eighteen science teachers from three districts participated in the project and study. They were a highly experienced group with an average of 16 years teaching, with strong classroom management skills, and good rapport with their students. All participants had at least two years of teaching experience; just three of the 18 teachers had fewer than five years of experience, and the remaining teachers had eight to over 30 years of experience. Approximately two-thirds of the teachers were female, and most were White. Many said they had been implementing "hands-on" and/or inquiry-based science lessons aligned with their state content standards. Approximately one-third of the teachers had received extensive training on NGSS; the rest had little or no familiarity with the science standards.

Participating teachers taught in five socioeconomically diverse public middle schools serving grades six through eight in three U.S. districts. Eight teachers taught in Title I schools (two schools), with one school having high proportions of White and Black students, and the other predominantly Southeast Asian and Hispanic students. The other teachers taught in relatively affluent schools (three schools) where the student population was either predominantly White, predominantly Southeast Asian, or predominantly White and South Asian. Enrollment in the teachers schools was approximately 450 per grade, except in one school with approximately 250 students per grade.

Districts were recruited through a national network of forward-thinking superintendents (Digital Promise's League of Innovative Schools). District partners were selected from those that expressed interest in the project on the basis of their capacity to develop and implement challenge based, NGSS-aligned curricula. Racial and economic diversity in their student demographic was also considered. Two of the districts were small, with only one middle school. The third district was mid-sized with three middle schools. One district was in a state that had adopted NGSS since its inception, while the other two districts were in states that were in the process of changing their state standards to better align with NGSS. The leaders who participated in the project included a curriculum coordinator/director, assistant superintendents, and a school principal, most of whom had prior training and experience with science education and/or student-centered learning.

\section{Data and Analysis}

Two researchers collected the following data throughout SY 2018-19:

- Teacher interview audio and transcripts (three interviews per teacher, each approximately one hour long)

- Classroom observations notes (three waves per teacher, each wave consisting of one to three class periods)

- Student focus group audio and transcripts (two waves per teacher; four to eight students per group, each approximately 40 minutes) 
- Notes and surveys from two two-day curriculum design workshops

- Notes on informal conversations and correspondences with teachers and school and district leaders

- Examples of science lessons and student work (additional to the challenge based lessons, teachers provided samples of "typical" and "NGSS-aligned" activities)

Teacher interviews were semi-structured and were conducted at the beginning of the project (baseline, late fall), after the first curricular design workshop and pilot of their first lesson (midline, early spring), and after the second curricular design workshop and pilot of their second lesson (endline, late spring). The questions focused on teacher perceptions of the challenge based lesson design, implementation, and outcomes, including lessons learned. Interview transcripts were summarized for each teacher, and themes were identified for each wave as well as longitudinally.

Student focus groups asked whether and why students liked the challenge based lessons, how they were impacted, what difficulties they experienced, and for feedback for improvement. Students' main ideas were summarized for each focus group and examined across for similarities and differences.

Observation notes were running notes focused mainly on teachers' instructional moves and overall lesson flow. These were used in conjunction with teacher interviews to sketch out the structures of the different challenge based lessons, which in turn were used to understand what the lessons looked like and where they can be improved.

Lessons and student work were shared by the teachers during the site visits or electronically. The lessons collected consisted mainly of student-facing material, such as handouts, slides, and readings. The student work collected were copies (or photos) of products that students had generated through the lesson, e.g., filled-out worksheets, projects, sketches in their notebooks. Supplementary information about the context, aim and flow of the lessons, was obtained through classroom observation (for all challenge based lessons, and some comparison lessons) and additional conversations with the teachers.

As mentioned in the beginning of Section 3, four science teachers and two education researchers who were unfamiliar with the project scored each lesson and student work on the deeper learning and science content rubrics. Two of the teachers had more than 10 years of experience teaching science in middle and upper elementary school, while the other two teachers were newer to their science teaching career (less than three years). All teachers had some experience teaching in Title I schools. Each scoring packet was a digital folder comprising of: a brief lesson overview created by researchers to look consistent across all lessons (including lesson topic, assignment description, student choice, duration, connection to prior lessons, description of group work involved if any, and grading criteria); lesson materials; and two student work samples. While most teachers submitted at least six samples of student work-two that exceeded their expectations, two that met their expectations, and two that did not meet their expectations-the scorers only analyzed 
two among those that either met or exceeded expectations. We decided not to score lessons that "did not meet" expectations because (1) our main objective was to understand the learning opportunities and outcomes when students complete the assignment to a reasonable extent, and (2) we knew from our observations that the work that "didn't meet teachers' expectations" were generally exceptions, rather than the norm, in terms of the quality of work that students produced.

The scorers spent two days at the Digital Promise office in San Mateo, CA, receiving training and scoring the lessons. All except one spent up to four additional hours scoring lessons remotely. The scoring order was randomized, and the same scorer who scored the lessons scored the student work. More than two-thirds of the lesson packets were scored by at least two scorers, and all except one lesson and more than 90 percent of the student work were scored by at least two scorers.

The research team analyzed the scores and gathered additional feedback on the rubric dimensions (from scorers and additional middle school science experts) to assess whether the rubric scores were of adequate quality to use for this analysis. This validation analysis, documented in Iwatani, Vang, Romero, \& Means (forthcoming), showed that the scorers, as a group, scored the lessons very consistently. The one-way random-effects average measures intraclass correlation (ICC) ranging from .87 to .94 for the deeper learning activity dimensions (all in the "excellent" range according to Cicchetti, 1994) and from .72 to .94 for the deeper learning student work (either the "good" or "excellent" range). However, the ICC for the science content dimensions (Appendix D) were only .57 (fair) and .53 (fair) for activity and student work. The rubric dimension scores correlated with one another and with the science content scores in patterns that we expected based on theory and observations, providing us with more confidence that the dimensions scores measured what we intended them to. Scorer comments and reviewers of the rubrics provided feedback on how specific elements can or should be improved, but on-the-whole agreed that the dimensions were important and clear, further indicating the trustworthiness of the scores for use in this research context.

The rubric scores were averaged across scorers so that every lesson and student work had one score per dimension. Ratings of " $N / A$ " were converted to " 0 " for this analysis since the population of interest for this project included all lessons (vs e.g., only secondary research lessons or only lessons that involved creating a product). We calculated mean scores for the three lesson types (typical, NGSS practices-aligned, and challenge based), and compared the means using one-way between-subjects analysis of variance (ANOVAs). To find the pattern of differences in rubric scores between the lesson types, we performed post hoc pairwise comparisons using the Bonferroni adjustment. For the two dimensions that violated the homogeneity of variance assumption (namely, the activity and student work ratings on critical secondary research), we performed Welch's test on the comparison to account for the violation. In addition, we calculated the effect size, Hedges' g-a measure of how large the average score differences are in terms of standard deviation units-for each comparison. 
It should be noted that initially we considered the challenge based lessons created in the first and second rounds of the project separately ("CBL1" and "CBL2," respectively). This was because we were not sure whether the two were different. Our initial ANOVA results and follow-up analyses indicated that the two groups of lessons were very similar in their characteristics, hence we considered the two groups as one (i.e., we compared the average of CBL1 and CBL2 with each of the comparison lessons) in subsequent analyses.

Finally, to determine if there were differences in deeper learning opportunities between Title I and non-Title I schools, we conducted two-sample t-tests comparing the deeper learning opportunity scores between Title I and non-Title I schools for typical, NGSS practices-aligned, and challenge based science lessons.

\section{Data Tables}

In this section, we present the data tables pertaining to the findings mentioned in this report. For interpretations of the tables as well as additional analyses we conducted, see Iwatani, Vang, Romero, \& Means (forthcoming).

Tables A1 presents descriptive statistics of each lesson type (i.e., typical, NGSS practices-aligned, and challenge based) for each rubric dimension. Tables A2 and A5 present oneway between-subjects ANOVA results for the deeper learning opportunities and student outcomes, respectively. Tables A3a and A3b present comparisons of deeper learning opportunities between challenge based and typical lessons, and challenge based and NGSS practices-aligned lessons, respectively.

Table A4 presents descriptive statistics of each lesson type for the student outcomes (as seen in the student work). Table A5 presents one-way between-subjects ANOVA results for the student outcomes. Tables A6a and A6b show comparisons of student outcomes between challenge based and typical lessons, and challenge based and NGSS practices-aligned lessons, respectively.

Table A7 displays the number of science lessons by lesson type for Title I and non-Title I schools. Table A8 presents the means and standard deviations for Title I and non-Title I schools by science lesson types. Results of comparison rubric scores between Title I and non-Title I schools for typical, NGSS practices-aligned, and challenge based science lessons are presented in Tables A9-A11. 
Table A1. Activity rubric score means and standard deviations and by lesson type

\begin{tabular}{|c|c|c|c|c|c|c|}
\hline \multirow[t]{2}{*}{ Learning opportunity } & \multicolumn{2}{|c|}{$\begin{array}{l}\text { Typical lessons } \\
(n=17)\end{array}$} & \multicolumn{2}{|c|}{$\begin{array}{l}\text { Practices-aligned } \\
(n=15)\end{array}$} & \multicolumn{2}{|c|}{$\begin{array}{l}\text { Challenge } \\
\text { based } \\
(n=39)\end{array}$} \\
\hline & $M$ & $S D$ & $M$ & $S D$ & $M$ & $S D$ \\
\hline $\begin{array}{l}\text { A1. Real-world } \\
\text { engagement }\end{array}$ & 0.93 & 0.65 & 0.99 & 0.73 & 2.37 & 0.94 \\
\hline A2. Self-direction & 0.99 & 0.94 & 1.51 & 1.27 & 2.04 & 1.08 \\
\hline $\begin{array}{l}\text { A3. Practicing science } \& \\
\text { engineering }\end{array}$ & 0.48 & 0.87 & 1.86 & 1.02 & 1.34 & 1.08 \\
\hline $\begin{array}{l}\text { A4. Critical secondary } \\
\text { research }\end{array}$ & 0.16 & 0.36 & 0.31 & 0.63 & 1.06 & 0.96 \\
\hline $\begin{array}{l}\text { A5. Substantive } \\
\text { collaboration }\end{array}$ & 0.45 & 0.79 & 1.54 & 1.23 & 1.94 & 1.16 \\
\hline $\begin{array}{l}\text { A6. Effective } \\
\text { communication }\end{array}$ & 0.54 & 0.82 & 0.67 & 0.84 & 1.44 & 1.03 \\
\hline Science content & 2.03 & 0.50 & 2.30 & 0.75 & 2.36 & 0.65 \\
\hline
\end{tabular}

Table A2. One-way between-subjects ANOVA results on whether mean activity rubric scores differ across lesson type

\begin{tabular}{|c|c|c|c|c|c|c|}
\hline Learning opportunity & $d f 1$ & $d f 2$ & $F$ & $p$ & $\eta^{2}$ & $\begin{array}{l}\text { partial } \\
\eta^{2}\end{array}$ \\
\hline A1. Real-world engagement & 3 & 67 & 17.76 & .00 & .44 & .44 \\
\hline A2. Self-direction & 3 & 67 & 3.68 & .02 & 14 & .14 \\
\hline $\begin{array}{l}\text { A3. Practicing science } \& \\
\text { engineering }\end{array}$ & 3 & 67 & 5.27 & .00 & .19 & .19 \\
\hline $\begin{array}{l}\text { A4. Critical secondary } \\
\text { research }\end{array}$ & 3 & 33 & 9.39 & .00 & .24 & .24 \\
\hline A5. Substantive collaboration & 3 & 67 & 7.74 & .00 & .26 & .26 \\
\hline A6. Effective communication & 3 & 67 & 5.08 & .00 & .19 & .19 \\
\hline Science content & 3 & 67 & 1.16 & .33 & .05 & .05 \\
\hline
\end{tabular}




\begin{tabular}{|c|c|c|c|c|c|c|c|}
\hline Learning opportunity & Estimate & $S E$ & $d f$ & $t$ & $p$ & $\begin{array}{l}\text { Adjusted } \\
p^{a}\end{array}$ & $E S^{b}$ \\
\hline $\begin{array}{l}\text { A1. Real-world } \\
\text { engagement }\end{array}$ & 1.43 & 0.25 & 67 & 5.82 & $<.001$ & $* \star \star$ & 1.75 \\
\hline A2. Self-direction & 1.05 & 0.32 & 67 & 3.26 & .004 & $* *$ & 1.04 \\
\hline $\begin{array}{l}\text { A3. Practicing science \& } \\
\text { engineering }\end{array}$ & 0.86 & 0.30 & 67 & 2.92 & 010 & * & 0.88 \\
\hline $\begin{array}{l}\text { A4. Critical secondary } \\
\text { research }{ }^{c}\end{array}$ & 0.90 & 0.18 & 44 & 4.96 & $<.001$ & $\star \star \star *$ & 1.24 \\
\hline $\begin{array}{l}\text { A5. Substantive } \\
\text { collaboration }\end{array}$ & 1.49 & 0.32 & 67 & 4.64 & $<.001$ & $\star \star *$ & 1.49 \\
\hline $\begin{array}{l}\text { A6. Effective } \\
\text { communication }\end{array}$ & 0.90 & 0.28 & 67 & 3.21 & .004 & $\star \star$ & 0.96 \\
\hline
\end{tabular}

a $p$-value doubled to control for Type I error.

${ }^{b}$ Average of Hedges' $g$ for CBL 1 and CBL2.

' Welch's ANOVA used due to heterogeneity of variance.

Table A3b. Comparisons of deeper learning opportunities between "NGSS practices-aligned" and challenge based lessons

\begin{tabular}{|l|l|l|l|l|l|l|l|}
\hline Learning opportunity & Estimate & $\boldsymbol{S E}$ & $\boldsymbol{d f}$ & $\boldsymbol{t}$ & $\boldsymbol{p}$ & $\begin{array}{l}\text { Adjusted } \\
\boldsymbol{p}^{\mathbf{a}}\end{array}$ & ES $^{\mathrm{b}}$ \\
\hline $\begin{array}{c}\text { A1. Real-world } \\
\text { engagement }\end{array}$ & 1.38 & 0.26 & 67 & 5.34 & $\begin{array}{l}< \\
.001\end{array}$ & $* \star *$ & 1.60 \\
\hline A2. Self-direction & 0.53 & 0.34 & 67 & 1.57 & .243 & & 0.46 \\
\hline $\begin{array}{c}\text { A3. Practicing science \& } \\
\text { engineering }\end{array}$ & -0.51 & 0.31 & 67 & -1.67 & .201 & & -0.50 \\
\hline $\begin{array}{c}\text { A4. Critical secondary } \\
\text { researchc }\end{array}$ & 0.75 & 0.23 & 41 & 3.29 & .002 & $* *$ & 0.92 \\
\hline $\begin{array}{c}\text { A5. Substantive } \\
\text { collaboration }\end{array}$ & 0.39 & 0.34 & 67 & 1.18 & .488 & & 0.34 \\
\hline $\begin{array}{c}\text { A6. Effective } \\
\text { communication }\end{array}$ & 0.77 & 0.29 & 67 & 2.64 & .021 & $*$ & 0.81 \\
\hline
\end{tabular}

a $p$-value doubled to control for Type I error.

${ }^{b}$ Average of Hedges' $g$ for CBL 1 and CBL2.

c Welch's ANOVA used due to heterogeneity of variance. 
Table A4. Average rubric scores and standard deviations for typical, practices-aligned, and challenge based lessons by student outcomes

\begin{tabular}{|c|c|c|c|c|c|c|}
\hline \multirow[t]{2}{*}{$\begin{array}{l}\text { Student outcomes (as seen } \\
\text { in student work)t }\end{array}$} & \multicolumn{2}{|c|}{$\begin{array}{l}\text { Typical lessons } \\
(n=34)\end{array}$} & \multicolumn{2}{|c|}{$\begin{array}{l}\text { Practices- } \\
\text { aligned lessons } \\
(n=30)\end{array}$} & \multicolumn{2}{|c|}{$\begin{array}{l}\text { Challenge based } \\
\text { lessons } \\
(n=78)\end{array}$} \\
\hline & $M$ & $S D$ & $M$ & $S D$ & $M$ & $S D$ \\
\hline S1. Did something relevant & 1.02 & 0.68 & 1.11 & 0.88 & 1.70 & 0.82 \\
\hline S2. Practiced science & 0.41 & 0.54 & 1.22 & 0.68 & 0.75 & 0.66 \\
\hline S3. Used engineering design & 0.38 & 0.80 & 1.06 & 1.43 & 0.75 & 0.90 \\
\hline $\begin{array}{l}\text { S4. Conducted critical } \\
\text { secondary research }\end{array}$ & 0.20 & 0.36 & 0.34 & 0.67 & 0.94 & 0.81 \\
\hline S5. Communicated effectively & 1.44 & 1.21 & 1.05 & 1.25 & 1.82 & 0.94 \\
\hline $\begin{array}{l}\text { Understood disciplinary core } \\
\text { ideas }\end{array}$ & 1.46 & 0.76 & 1.77 & 0.87 & 1.46 & 0.69 \\
\hline
\end{tabular}

Table A5. One-way between-subjects ANOVA results on whether mean student work rubric scores differ across lesson type

\begin{tabular}{|l|l|l|l|l|l|l|}
\hline $\begin{array}{l}\text { Student outcomes (as seen } \\
\text { in student work) }\end{array}$ & $\boldsymbol{d f 1}$ & $\boldsymbol{d f 2}$ & $\boldsymbol{F}$ & $\boldsymbol{p}$ & $\boldsymbol{\eta}^{2}$ & $\begin{array}{l}\text { partial } \\
\boldsymbol{\eta}^{2}\end{array}$ \\
\hline S1. Did something relevant & 3 & 100 & 6.34 & $<.01$ & .16 & .16 \\
\hline S2. Practiced science & 3 & 97 & 6.36 & $<.01$ & .16 & .16 \\
\hline S3. Used engineering design & 3 & 98 & 1.64 & .18 & .05 & .05 \\
\hline $\begin{array}{l}\text { S4. Conducted critical } \\
\text { secondary research }\end{array}$ & 3 & 48 & 13.32 & $<.01$ & .23 & .23 \\
\hline S5. Communicated effectively & 3 & 99 & 4.70 & $<.001$ & .13 & .13 \\
\hline $\begin{array}{l}\text { Understood disciplinary core } \\
\text { ideas }\end{array}$ & 3 & 101 & 2.91 & $<.04$ & .08 & .08 \\
\hline
\end{tabular}

a Welch's ANOVA used due to heterogeneity of variance, although $\eta 2$ values were estimated from standard ANOVA. 
Table A6a. Simple comparisons of student outcomes between typical and challenge based lessons

\begin{tabular}{|l|l|l|l|l|l|l|l|}
\hline $\begin{array}{l}\text { Student outcomes (as } \\
\text { seen in student work) }\end{array}$ & estimate & $\boldsymbol{S E}$ & $\boldsymbol{d f}$ & $\boldsymbol{t}$ & $\boldsymbol{p}$ & $\begin{array}{l}\text { Adjusted } \\
\boldsymbol{p}^{\mathrm{a}}\end{array}$ & $\boldsymbol{E S}^{\mathrm{b}}$ \\
\hline S1. Did something relevant & 0.68 & 0.20 & 100 & 3.36 & .002 & $\star \star$ & 0.76 \\
\hline S2. Practiced science & 0.34 & 0.16 & 97 & 2.19 & .063 & & 0.48 \\
\hline $\begin{array}{l}\text { S4. Conducted critical } \\
\text { secondary research }\end{array}$ & 0.74 & 0.13 & 80 & 5.79 & $<.001$ & $\star \star \star$ & 1.02 \\
\hline $\begin{array}{l}\text { S5. Communicated } \\
\text { effectively }\end{array}$ & 0.39 & 0.27 & 99 & 1.44 & .304 & & 0.31 \\
\hline $\begin{array}{l}\text { Understood disciplinary } \\
\text { core ideas }\end{array}$ & $<.01$ & 0.18 & 101 & 0.02 & 1.000 & & 0.02 \\
\hline
\end{tabular}

a $p$-value doubled to control for Type I error.

${ }^{b}$ Average of Hedges' $g$ for CBL 1 and CBL2.

c Welch's ANOVA used due to heterogeneity of variance.

Table A6b. Simple comparisons of student outcomes between NGSS practices-aligned and challenge based lessons

\begin{tabular}{|l|l|l|l|l|l|l|l|}
\hline $\begin{array}{l}\text { Student outcomes (as } \\
\text { seen in student work) }\end{array}$ & estimate & SE & $\boldsymbol{d f}$ & $\boldsymbol{t}$ & $\boldsymbol{p}$ & $\begin{array}{l}\text { Adjusted } \\
\boldsymbol{p}^{\mathbf{a}}\end{array}$ & $\boldsymbol{E S}^{\mathbf{b}}$ \\
\hline $\begin{array}{l}\text { S1. Did something } \\
\text { relevant }\end{array}$ & 0.59 & 0.21 & 100 & 2.75 & .014 & $*$ & 0.58 \\
\hline S2. Practiced science & -0.47 & 0.17 & 97 & -2.71 & .016 & $*$ & -0.59 \\
\hline $\begin{array}{l}\text { S4. Conducted critical } \\
\text { secondary research }\end{array}$ & 0.60 & 0.19 & 42 & 3.13 & .003 & $* *$ & 0.67 \\
\hline $\begin{array}{c}\text { S5. Communicated } \\
\text { effectively }\end{array}$ & 0.77 & 0.28 & 99 & 2.78 & .013 & $*$ & 0.61 \\
\hline $\begin{array}{l}\text { Understood disciplinary } \\
\text { core ideas }\end{array}$ & -0.31 & 0.19 & 101 & -1.61 & .222 & & -0.33 \\
\hline
\end{tabular}

a $p$-value doubled to control for Type I error.

' Average of Hedges' $g$ for CBL 1 and CBL2.

' Welch's ANOVA used due to heterogeneity of variance. 
Table A7. Number of lessons (by lesson type) in Title I and non-Title I schools

\begin{tabular}{|l|l|l|l|l|}
\hline School Status & Typical lessons & $\begin{array}{l}\text { Practices- } \\
\text { aligned }\end{array}$ & $\begin{array}{l}\text { Challenge } \\
\text { based }\end{array}$ & Total \\
\hline Title I & 10 & 7 & 18 & 35 \\
\hline Non-Title I & 7 & 8 & 21 & 36 \\
\hline
\end{tabular}

Table A8. Deeper learning scores and standard deviations for Title I and non-Title I schools by lesson type

\begin{tabular}{|c|c|c|c|c|c|c|c|}
\hline \multirow[t]{2}{*}{$\begin{array}{l}\text { Learning } \\
\text { opportunity }\end{array}$} & \multirow[t]{2}{*}{ School Status } & \multicolumn{2}{|c|}{$\begin{array}{l}\text { Typical } \\
\text { lessons }\end{array}$} & \multicolumn{2}{|c|}{$\begin{array}{l}\text { Practices- } \\
\text { aligned }\end{array}$} & \multicolumn{2}{|c|}{$\begin{array}{l}\text { Challenge } \\
\text { based }\end{array}$} \\
\hline & & $M$ & $S D$ & $M$ & $S D$ & $M$ & $S D$ \\
\hline \multirow{2}{*}{$\begin{array}{l}\text { A1. Real-world } \\
\text { engagement }\end{array}$} & Title I & 0.90 & 0.54 & 1.21 & 0.92 & 2.61 & 0.95 \\
\hline & Non-Title I & 0.98 & 0.82 & 0.79 & 0.50 & 2.22 & 0.96 \\
\hline \multirow[t]{2}{*}{ A2. Self-direction } & Title I & 0.85 & 1.04 & 1.64 & 1.10 & 2.16 & 1.24 \\
\hline & Non-Title I & 1.19 & 0.82 & 1.40 & 1.46 & 1.92 & 0.94 \\
\hline \multirow{2}{*}{$\begin{array}{l}\text { A3. Practicing } \\
\text { science \& } \\
\text { engineering }\end{array}$} & Title I & 0.35 & 0.63 & 1.26 & 1.10 & 1.27 & 1.06 \\
\hline & Non-Title I & 0.67 & 1.15 & 2.38 & 0.61 & 1.37 & 1.07 \\
\hline \multirow{2}{*}{$\begin{array}{l}\text { A4. Critical } \\
\text { secondary } \\
\text { research }\end{array}$} & Title I & 0.10 & 0.32 & 0.38 & 0.57 & 1.19 & 1.00 \\
\hline & Non-Title I & 0.24 & 0.42 & 0.25 & 0.71 & 0.96 & 0.88 \\
\hline \multirow{2}{*}{$\begin{array}{l}\text { A5. Substantive } \\
\text { collaboration }\end{array}$} & Title I & 0.20 & 0.63 & 1.00 & 1.12 & 2.12 & 1.10 \\
\hline & Non-Title I & 0.81 & 0.90 & 2.02 & 1.17 & 1.83 & 1.20 \\
\hline \multirow{2}{*}{$\begin{array}{l}\text { A6. Effective } \\
\text { communication }\end{array}$} & Title I & 0.23 & 0.45 & 0.48 & 0.58 & 1.71 & 1.17 \\
\hline & Non-Title I & 0.98 & 1.05 & 0.83 & 1.02 & 1.25 & 0.92 \\
\hline \multirow[t]{2}{*}{ Science content } & Title I & 1.95 & 0.42 & 1.90 & 0.79 & 2.21 & 0.69 \\
\hline & Non-Title I & 2.14 & 0.63 & 2.65 & 0.55 & 2.49 & 0.58 \\
\hline
\end{tabular}


Table A9. Whether typical lessons differ in activity subric scores between Title I and non-Title I schools

\begin{tabular}{|l|l|l|l|l|}
\hline Learning opportunity & $\boldsymbol{t}$ & $\boldsymbol{d f}$ & $\boldsymbol{p}$ & Hedges' g \\
\hline A1. Real-world engagement & 0.22 & 9.61 & .83 & 0.12 \\
\hline A2. Self-direction & 0.75 & 4.69 & .46 & 0.36 \\
\hline A3. Practicing science \& engineering & 0.66 & 8.52 & .53 & 0.37 \\
\hline A4. Critical secondary research & 0.74 & 10.64 & .48 & 0.39 \\
\hline A5. Substantive collaboration & 1.55 & 10.07 & .15 & 0.82 \\
\hline A6. Effective communication & 1.77 & 7.54 & .12 & 1.01 \\
\hline Science content & 0.71 & 9.66 & .49 & 0.38 \\
\hline
\end{tabular}

Table A10. Whether NGSS practices-aligned lessons differ in activity rubric scores between Title I and non-Title I schools

\begin{tabular}{|l|l|l|l|l|}
\hline Learning opportunity & $\boldsymbol{t}$ & $\boldsymbol{d} \boldsymbol{f}$ & $\boldsymbol{p}$ & Hedges' $\boldsymbol{g}$ \\
\hline A1. Real-world engagement & -1.09 & 9.03 & .31 & -0.59 \\
\hline A2. Self-direction & -0.37 & 12.75 & .72 & -0.19 \\
\hline A3. Practicing science \& engineering & 2.38 & 9.11 & .04 & 1.30 \\
\hline A4. Critical secondary research & -0.40 & 12.93 & .70 & -0.20 \\
\hline A5. Substantive collaboration & 1.72 & 12.87 & .11 & 0.90 \\
\hline A6. Effective communication & 0.84 & 11.31 & .42 & 0.42 \\
\hline Science content & 2.09 & 10.51 & .06 & 1.12 \\
\hline
\end{tabular}


Table A11. Whether challenge based lessons differ in activity rubric scores between Title I and non-Title I schools

\begin{tabular}{|l|l|l|l|l|}
\hline Learning opportunity & $\boldsymbol{t}$ & $\boldsymbol{d} f$ & $\boldsymbol{p}$ & Hedges' g \\
\hline A1. Real-world engagement & -1.25 & 36.20 & .22 & -0.40 \\
\hline A2. Self-direction & -0.67 & 31.46 & .50 & -0.22 \\
\hline A3. Practicing science \& engineering & 0.30 & 36.18 & .76 & 0.10 \\
\hline A4. Critical secondary research & -0.73 & 34.26 & .47 & -0.24 \\
\hline A5. Substantive collaboration & -0.77 & 36.81 & .45 & -0.25 \\
\hline A6. Effective communication & -1.35 & 32.08 & .19 & -0.44 \\
\hline Science content & 1.36 & 33.53 & .18 & 0.45 \\
\hline
\end{tabular}




\section{Appendix B. Activity Rubric}

These were used for the scoring described in this report. The updated versions based on feedback from the scorers and reliability analyses are available in Digital Promise's

\section{Challenge Based Science Learning Toolkit.}

Activity Dimension 1: Activity calls for students to engage with real-world phenomena* or problems that connect with their interests and values.

\begin{tabular}{|c|c|c|c|c|}
\hline 0 & 1 & 2 & 3 & 4 \\
\hline $\begin{array}{l}\text { Activity } \\
\text { doesn't involve } \\
\text { real-world } \\
\text { phenomena or } \\
\text { problems (e.g., } \\
\text { it asks students } \\
\text { to learn facts } \\
\text { or a theory in a } \\
\text { decontextualized } \\
\text { way). }\end{array}$ & $\begin{array}{l}\text { Activity involves } \\
\text { a real-world } \\
\text { phenomenon } \\
\text { and/or problem. } \\
\text { Activity doesn't } \\
\text { call for students } \\
\text { to invest much } \\
\text { time, emotion, } \\
\text { or thinking } \\
\text { towards the } \\
\text { phenomenon } \\
\text { or problem. }\end{array}$ & $\begin{array}{l}\text { Activity involves } \\
\text { a real-world } \\
\text { phenomenon } \\
\text { and/or problem. } \\
\text { Activity calls } \\
\text { for students } \\
\text { to invest time } \\
\text { and thinking } \\
\text { towards the } \\
\text { phenomenon or } \\
\text { problem. } \\
\text { Activity doesn't } \\
\text { attempt to } \\
\text { engage students } \\
\text { emotionally. }\end{array}$ & $\begin{array}{l}\text { Activity involves } \\
\text { a real-world } \\
\text { phenomenon } \\
\text { and/or problem. } \\
\text { Activity calls } \\
\text { for students } \\
\text { to invest time } \\
\text { and thinking } \\
\text { towards the } \\
\text { phenomenon or } \\
\text { problem. } \\
\text { Activity } \\
\text { attempts to } \\
\text { engage students } \\
\text { emotionally by } \\
\text { connecting with } \\
\text { their interests } \\
\text { and values. }\end{array}$ & $\begin{array}{l}\text { Activity involves } \\
\text { a real-world } \\
\text { phenomenon } \\
\text { and/or problem. } \\
\text { Activity calls } \\
\text { for students } \\
\text { to invest time } \\
\text { and thinking } \\
\text { towards the } \\
\text { phenomenon } \\
\text { or problem. } \\
\text { Activity attempts } \\
\text { to engage } \\
\text { students } \\
\text { emotionally by } \\
\text { connecting with } \\
\text { their interests } \\
\text { and values. } \\
\text { Learning about } \\
\text { this topic can } \\
\text { greatly expand } \\
\text { students' } \\
\text { awareness, and } \\
\text { change the way } \\
\text { they think, feel, } \\
\text { or act. }\end{array}$ \\
\hline $\begin{array}{l}\text { Examples: } \\
\text { Worksheet on } \\
\text { Punnett squares. } \\
\text { Demonstration of } \\
\text { evaporation and } \\
\text { condensation } \\
\text { of water. }\end{array}$ & $\begin{array}{l}\text { Examples: } \\
\text { Reading or } \\
\text { watching a video } \\
\text { about the impact } \\
\text { of deforestation } \\
\text { and answering } \\
\text { questions. }\end{array}$ & $\begin{array}{l}\text { Examples: } \\
\text { Designing the } \\
\text { tallest building } \\
\text { possible. } \\
\text { Investigating } \\
\text { how finches } \\
\text { have evolved } \\
\text { over time. }\end{array}$ & $\begin{array}{l}\text { Examples: } \\
\text { Designing a } \\
\text { more effective } \\
\text { layout for the } \\
\text { school cafeteria. } \\
\text { Investigating } \\
\text { the nutritional } \\
\text { content in chips } \\
\text { vs vegetables. }\end{array}$ & $\begin{array}{l}\text { Examples: } \\
\text { Designing a } \\
\text { more effective } \\
\text { home layout } \\
\text { for a local } \\
\text { resident who is } \\
\text { paraplegic. } \\
\text { Investigating } \\
\text { the nutritional } \\
\text { content in food } \\
\text { that students } \\
\text { want to learn } \\
\text { more about. }\end{array}$ \\
\hline
\end{tabular}

*Note: "Phenomena are observable events in nature (or our lives) that connect to multiple NGSS disciplinary core ideas, such as Finnish Snow Trees or the behavior of bees" (Maltese, n.d.). 
Activity Dimension 2: Activity calls for students to guide their own learning of science or engineering.

\begin{tabular}{|c|c|c|c|c|}
\hline 0 & 1 & 2 & 3 & 4 \\
\hline $\begin{array}{l}\text { Activity calls } \\
\text { for students } \\
\text { to follow the } \\
\text { teacher's lead } \\
\text { every step of } \\
\text { the way. }\end{array}$ & $\begin{array}{l}\text { Activity calls } \\
\text { for students } \\
\text { to make } \\
\text { surface-level } \\
\text { decisions about } \\
\text { their learning } \\
\text { experience. } \\
\text { The decisions } \\
\text { aren't directly } \\
\text { tied to science } \\
\text { or engineering. }\end{array}$ & $\begin{array}{l}\text { Activity calls } \\
\text { for students } \\
\text { to make a few } \\
\text { short-term } \\
\text { decisions about } \\
\text { their learning } \\
\text { experience. } \\
\text { The decisions } \\
\text { are directly tied } \\
\text { to science or } \\
\text { engineering. } \\
\text { These decisions } \\
\text { don't really } \\
\text { impact what, } \\
\text { how, and to } \\
\text { what degree } \\
\text { students will } \\
\text { learn the } \\
\text { science or } \\
\text { engineering. }\end{array}$ & $\begin{array}{l}\text { Activity calls } \\
\text { for students } \\
\text { to make a } \\
\text { substantive } \\
\text { decision that } \\
\text { would impact } \\
\text { what, how or } \\
\text { to what degree } \\
\text { they learn the } \\
\text { science, or how } \\
\text { they engineer } \\
\text { solutions. } \\
\text { Students are } \\
\text { not prompted } \\
\text { to reflect } \\
\text { on and take } \\
\text { responsibility } \\
\text { for their own } \\
\text { learning (i.e., } \\
\text { not provided the } \\
\text { opportunity to } \\
\text { reflect on and } \\
\text { adjust } \\
\text { their decisions). }\end{array}$ & $\begin{array}{l}\text { Activity calls for } \\
\text { students to make } \\
\text { a substantive } \\
\text { decision about } \\
\text { what, how, or } \\
\text { to what degree } \\
\text { they learn the } \\
\text { science, or how } \\
\text { they engineer } \\
\text { solutions. } \\
\text { They are } \\
\text { prompted } \\
\text { to take } \\
\text { responsibility } \\
\text { for their own } \\
\text { learning (i.e., } \\
\text { to reflect on } \\
\text { and adjust } \\
\text { their decisions, } \\
\text { making course } \\
\text { corrections } \\
\text { as necessary). }\end{array}$ \\
\hline Examples: & Examples: & Examples: & Examples: & Examples: \\
\hline $\begin{array}{l}\text { Students read and } \\
\text { answer questions } \\
\text { about the reading. }\end{array}$ & $\begin{array}{l}\text { Students are } \\
\text { prompted to } \\
\text { choose color, } \\
\text { font, style, } \\
\text { layout, or } \\
\text { order of simple } \\
\text { sub-tasks. } \\
\text { Students are told } \\
\text { they may listen } \\
\text { to music if the } \\
\text { want, and do } \\
\text { their work in the } \\
\text { library } \\
\text { or outside. }\end{array}$ & $\begin{array}{l}\text { Students can } \\
\text { choose which } \\
\text { species they cite } \\
\text { as an illustrative } \\
\text { example of a } \\
\text { predator, but } \\
\text { they don't do } \\
\text { much research } \\
\text { on them. } \\
\text { Students can } \\
\text { choose among } \\
\text { different } \\
\text { available } \\
\text { materials, } \\
\text { product types, } \\
\text { or optimization } \\
\text { processes that } \\
\text { yield similar } \\
\text { outcomes. }\end{array}$ & $\begin{array}{l}\text { Students can } \\
\text { choose a } \\
\text { science learning } \\
\text { topic, question, } \\
\text { goal, path, tool, } \\
\text { or product. } \\
\text { Students } \\
\text { can choose } \\
\text { engineering } \\
\text { problem, } \\
\text { success } \\
\text { criteria, design } \\
\text { constraints, and } \\
\text { development } \\
\text { and/or } \\
\text { optimization } \\
\text { process, } \\
\text { which make a } \\
\text { difference to the } \\
\text { solution's quality. }\end{array}$ & $\begin{array}{l}\text { Students are } \\
\text { prompted to do } \\
\text { what's described } \\
\text { on the column } \\
\text { to the left, and } \\
\text { to brainstorm } \\
\text { pros and cons } \\
\text { of their decision } \\
\text { through check- } \\
\text { ins with teacher } \\
\text { or classmates. } \\
\text { Students } \\
\text { are asked to } \\
\text { produce a } \\
\text { summative } \\
\text { reflection on } \\
\text { decisions they } \\
\text { made and } \\
\text { their impact. }\end{array}$ \\
\hline
\end{tabular}




\begin{tabular}{|c|c|c|c|c|}
\hline 0 & 1 & 2 & 3 & 4 \\
\hline $\begin{array}{l}\text { Activity does } \\
\text { not call for } \\
\text { students to learn } \\
\text { about scientific } \\
\text { principles or } \\
\text { engineering } \\
\text { designs. } \\
\text { OR } \\
\text { Activity calls for } \\
\text { students to just } \\
\text { read, hear, or } \\
\text { watch videos } \\
\text { about scientific } \\
\text { principles or } \\
\text { engineering } \\
\text { designs, without } \\
\text { experiencing } \\
\text { them directly. }\end{array}$ & $\begin{array}{l}\text { Activity calls for } \\
\text { students to get } \\
\text { some first-hand } \\
\text { experience } \\
\text { related to } \\
\text { the principle } \\
\text { / design, but } \\
\text { it is either in } \\
\text { the form of } \\
\text { demonstration } \\
\text { or confirmation. }\end{array}$ & $\begin{array}{l}\text { Activity calls } \\
\text { for students } \\
\text { to discover } \\
\text { underlying } \\
\text { principles / } \\
\text { effective designs } \\
\text { through direct } \\
\text { experience. } \\
\text { Activity is } \\
\text { excessively } \\
\text { scaffolded (e.g., } \\
\text { all students are } \\
\text { guaranteed } \\
\text { the discovery } \\
\text { if they follow } \\
\text { directions). }\end{array}$ & $\begin{array}{l}\text { Activity calls } \\
\text { for students } \\
\text { to discover } \\
\text { underlying } \\
\text { principles / } \\
\text { effective designs } \\
\text { through direct } \\
\text { experience, } \\
\text { without } \\
\text { excessive } \\
\text { scaffolding. } \\
\text { It doesn't call } \\
\text { for students } \\
\text { to articulate } \\
\text { connections } \\
\text { between the } \\
\text { activity and } \\
\text { scientific } \\
\text { principles, } \\
\text { or test the } \\
\text { effectiveness of } \\
\text { their designs. }\end{array}$ & $\begin{array}{l}\text { Activity calls } \\
\text { for students } \\
\text { to discover } \\
\text { underlying } \\
\text { principles / } \\
\text { effective designs } \\
\text { through direct } \\
\text { experience, } \\
\text { without } \\
\text { excessive } \\
\text { scaffolding. } \\
\text { It calls for } \\
\text { students to } \\
\text { articulate the } \\
\text { connection } \\
\text { between the } \\
\text { principles } \\
\text { and their } \\
\text { experience, or } \\
\text { the implications } \\
\text { of their test } \\
\text { results to } \\
\text { their design. }\end{array}$ \\
\hline Examples: & Examples: & Examples: & Examples: & Examples: \\
\hline $\begin{array}{l}\text { Practicing skills } \\
\text { they already } \\
\text { know. } \\
\text { Lecture, reading, } \\
\text { and/or video on } \\
\text { soil erosion. }\end{array}$ & $\begin{array}{l}\text { Students } \\
\text { learn about } \\
\text { conservation } \\
\text { of mass, and } \\
\text { do a lab that } \\
\text { illustrates it. }\end{array}$ & $\begin{array}{l}\text { Lab or design } \\
\text { task with } \\
\text { step-by-step } \\
\text { instructions } \\
\text { so discovery is } \\
\text { guaranteed. } \\
\text { "Aimless design" }\end{array}$ & $\begin{array}{l}\text { Lab where } \\
\text { students actually } \\
\text { play/explore, } \\
\text { and have to } \\
\text { express what } \\
\text { they learned. }\end{array}$ & $\begin{array}{l}\text { What's on the } \\
\text { left column, } \\
\text { but with added } \\
\text { requirement } \\
\text { to discuss } \\
\text { limitations to } \\
\text { discovery/ } \\
\text { design. }\end{array}$ \\
\hline
\end{tabular}


Activity Dimension 4: Activity calls for students to conduct critical background research on their own.

\begin{tabular}{|c|c|c|c|c|}
\hline 0 & 1 & 2 & 3 & 4 \\
\hline $\begin{array}{l}\text { Activity does } \\
\text { not ask students } \\
\text { to obtain } \\
\text { information } \\
\text { OR } \\
\text { Activity calls } \\
\text { for students } \\
\text { to obtain } \\
\text { information from } \\
\text { just one source or } \\
\text { does not specify } \\
\text { that information } \\
\text { must come from } \\
\text { multiple sources. } \\
\text { OR } \\
\text { Assignment is not } \\
\text { complex enough } \\
\text { that multiple } \\
\text { sources are not } \\
\text { needed. }\end{array}$ & $\begin{array}{l}\text { Activity calls } \\
\text { for students } \\
\text { to obtain } \\
\text { information } \\
\text { from multiple } \\
\text { sources. }\end{array}$ & $\begin{array}{l}\text { Activity calls } \\
\text { for students } \\
\text { to obtain } \\
\text { information } \\
\text { from multiple } \\
\text { appropriate } \\
\text { sources. } \\
\text { It asks students } \\
\text { to combine } \\
\text { information } \\
\text { from multiple } \\
\text { sources to } \\
\text { form answers } \\
\text { expressed using } \\
\text { his/her own } \\
\text { words. }\end{array}$ & $\begin{array}{l}\text { Activity calls } \\
\text { for students } \\
\text { to obtain } \\
\text { information } \\
\text { from multiple } \\
\text { appropriate } \\
\text { sources. } \\
\text { It asks students } \\
\text { to combine the } \\
\text { information from } \\
\text { multiple sources } \\
\text { to explain a } \\
\text { phenomenon } \\
\text { or suggest a } \\
\text { solution to a } \\
\text { design problem. }\end{array}$ & $\begin{array}{l}\text { Activity calls } \\
\text { for students } \\
\text { to obtain } \\
\text { information } \\
\text { from multiple } \\
\text { appropriate } \\
\text { sources. } \\
\text { It asks students } \\
\text { to combine the } \\
\text { information from } \\
\text { multiple sources } \\
\text { to explain a } \\
\text { phenomenon } \\
\text { or suggest a } \\
\text { solution to a } \\
\text { design problem. } \\
\text { It asks students } \\
\text { to attend to } \\
\text { the credibility, } \\
\text { accuracy, and } \\
\text { possible bias of } \\
\text { each publication } \\
\text { and method } \\
\text { used. }\end{array}$ \\
\hline
\end{tabular}


Activity Dimension 5: Activity calls for students to collaborate substantively.

\begin{tabular}{|c|c|c|c|c|}
\hline 0 & 1 & 2 & 3 & 4 \\
\hline $\begin{array}{l}\text { Activity does not } \\
\text { call for students } \\
\text { to work together. }\end{array}$ & $\begin{array}{l}\text { Activity calls } \\
\text { for students to } \\
\text { work together, } \\
\text { but does not call } \\
\text { for students to } \\
\text { create a shared } \\
\text { product(s). }\end{array}$ & $\begin{array}{l}\text { Activity calls } \\
\text { for students to } \\
\text { work together } \\
\text { towards a shared } \\
\text { product(s). } \\
\text { For many } \\
\text { groups, the } \\
\text { product(s) can } \\
\text { be completed } \\
\text { with one round } \\
\text { of discussion } \\
\text { and decision- } \\
\text { making (e.g., on } \\
\text { what to do and } \\
\text { who does } \\
\text { which part). }\end{array}$ & $\begin{array}{l}\text { Activity calls for } \\
\text { students to work } \\
\text { towards a shared } \\
\text { product(s). } \\
\text { The product } \\
\text { is sufficiently } \\
\text { complex such } \\
\text { that for most } \\
\text { student groups, } \\
\text { one round of } \\
\text { discussion is } \\
\text { likely to be } \\
\text { insufficient for } \\
\text { its successful } \\
\text { completion. }\end{array}$ & $\begin{array}{l}\text { Activity calls } \\
\text { for students to } \\
\text { work towards a } \\
\text { shared product. } \\
\text { The product } \\
\text { is sufficiently } \\
\text { complex that } \\
\text { multiple rounds } \\
\text { of agreement } \\
\text { on what-to-do } \\
\text { and who-does- } \\
\text { what-part are } \\
\text { necessary for } \\
\text { the successful } \\
\text { completion of } \\
\text { the product. } \\
\text { In addition, } \\
\text { activity } \\
\text { specifically calls } \\
\text { for all students } \\
\text { to explicitly } \\
\text { attend their } \\
\text { process and/ } \\
\text { or efficacy of } \\
\text { collaboration } \\
\text { (e.g., asking } \\
\text { them to } \\
\text { establish group } \\
\text { norms or reflect } \\
\text { on the extent } \\
\text { to which they } \\
\text { collaborated } \\
\text { successfully). }\end{array}$ \\
\hline
\end{tabular}


Activity Dimension 6: Activity calls for students to effectively organize, style, and format their communication.

\begin{tabular}{|c|c|c|c|c|}
\hline 0 & 1 & 2 & 3 & 4 \\
\hline $\begin{array}{l}\text { Activity does } \\
\text { not involve } \\
\text { communicating } \\
\text { information to an } \\
\text { audience. } \\
\text { OR } \\
\text { Activity calls } \\
\text { for students to } \\
\text { communicate } \\
\text { simple } \\
\text { information. }\end{array}$ & $\begin{array}{l}\text { Activity calls } \\
\text { for students to } \\
\text { communicate } \\
\text { simple } \\
\text { information. } \\
\text { It calls for } \\
\text { students to } \\
\text { effectively } \\
\text { format and style } \\
\text { the information. }\end{array}$ & $\begin{array}{l}\text { Activity calls } \\
\text { for students to } \\
\text { communicate } \\
\text { fairly complex } \\
\text { or nuanced } \\
\text { information. } \\
\text { It calls for } \\
\text { students to } \\
\text { effectively } \\
\text { format and style } \\
\text { the information. }\end{array}$ & $\begin{array}{l}\text { Activity calls } \\
\text { for students to } \\
\text { communicate } \\
\text { fairly complex } \\
\text { or nuanced } \\
\text { information. } \\
\text { It calls for } \\
\text { students to } \\
\text { effectively } \\
\text { format, style, } \\
\text { and organize } \\
\text { (structure) their } \\
\text { communication. }\end{array}$ & $\begin{array}{l}\text { Activity calls } \\
\text { for students to } \\
\text { communicate } \\
\text { a substantial } \\
\text { amount of } \\
\text { information. } \\
\text { It calls for } \\
\text { students to } \\
\text { effectively } \\
\text { format, style, } \\
\text { and organize } \\
\text { (structure) their } \\
\text { communication. } \\
\text { It calls for } \\
\text { students to } \\
\text { improve their } \\
\text { communication } \\
\text { approach based } \\
\text { on feedback. }\end{array}$ \\
\hline Examples: & Examples: & Examples: & Examples: & Examples: \\
\hline $\begin{array}{l}\text { Educational } \\
\text { games; Taking } \\
\text { notes } \\
\text { Multiple choice } \\
\text { and short answer } \\
\text { questions. }\end{array}$ & $\begin{array}{l}\text { Poster } \\
\text { conveying } \\
\text { the message } \\
\text { that smoking } \\
\text { is harmful for } \\
\text { your lungs, } \\
\text { that follows } \\
\text { certain format } \\
\text { guidelines. } \\
\text { Slideshow } \\
\text { illustrating key } \\
\text { vocabulary } \\
\text { terms of a unit } \\
\text { that's assessed } \\
\text { on format. }\end{array}$ & $\begin{array}{l}\text { Draw and } \\
\text { explain the } \\
\text { process of } \\
\text { mitosis. Drawing } \\
\text { and explanation } \\
\text { must follow } \\
\text { certain format } \\
\text { guidelines (e.g., } \\
\text { clear, legible, } \\
\text { color-coded). }\end{array}$ & $\begin{array}{l}\text { Essay on how } \\
\text { pollution affects } \\
\text { meiosis of fish } \\
\text { (where students } \\
\text { must combine } \\
\text { and organize } \\
\text { the topics } \\
\text { themselves). }\end{array}$ & $\begin{array}{l}\text { Debate or } \\
\text { moderated panel } \\
\text { discussion on a } \\
\text { scientific topic. } \\
\text { Lessons that } \\
\text { involve feedback } \\
\text { sessions (by } \\
\text { teacher or } \\
\text { student) as } \\
\text { part of the } \\
\text { developmental } \\
\text { process for } \\
\text { communicating } \\
\text { information. }\end{array}$ \\
\hline
\end{tabular}

Note: This is a generic rubric that can be used to assess a variety of communication products (e.g., presentations, videos, and posters). 


\section{Appendix C. Student Work Rubric}

These were used for the scoring described in this report. The updated versions based on feedback from the scorers and reliability analyses are available in Digital Promise's

Challenge Based Science Learning Toolkit.

Student Work Dimension 1: Student(s) did/created something potentially valuable to others as part of their learning.

\begin{tabular}{|c|c|c|c|c|c|}
\hline N/A & 0 & 1 & 2 & 3 & 4 \\
\hline $\begin{array}{l}\text { Assignment } \\
\text { didn't } \\
\text { ask for } \\
\text { student(s) } \\
\text { to create } \\
\text { something. }\end{array}$ & $\begin{array}{l}\text { Student } \\
\text { product is } \\
\text { missing, } \\
\text { incomplete, } \\
\text { and/or } \\
\text { misses } \\
\text { the point. }\end{array}$ & $\begin{array}{l}\text { A product } \\
\text { was created, } \\
\text { but its } \\
\text { interest/ } \\
\text { value to } \\
\text { others is } \\
\text { questionable } \\
\text { (e.g., purpose } \\
\text { is unclear } \\
\text { or not } \\
\text { compelling). }\end{array}$ & $\begin{array}{l}\text { Student did/ } \\
\text { created } \\
\text { something that } \\
\text { could be of } \\
\text { interest/ value } \\
\text { to others. } \\
\text { But the } \\
\text { product is not } \\
\text { particularly } \\
\text { original or } \\
\text { creative. } \\
\text { It mainly } \\
\text { repurposes } \\
\text { already } \\
\text { available } \\
\text { information in } \\
\text { a simple way. }\end{array}$ & $\begin{array}{l}\text { Student did/ } \\
\text { created } \\
\text { something that } \\
\text { could be of } \\
\text { interest/value } \\
\text { to others. } \\
\text { The student's } \\
\text { work is } \\
\text { original or } \\
\text { creative. }\end{array}$ & $\begin{array}{l}\text { Student did/ } \\
\text { created } \\
\text { something } \\
\text { that could be } \\
\text { of interest/ } \\
\text { value to } \\
\text { others. } \\
\text { The student's } \\
\text { work is } \\
\text { original or } \\
\text { creative. } \\
\text { In addition, } \\
\text { student } \\
\text { provided } \\
\text { evidence that } \\
\text { either (1) they } \\
\text { thoughtfully } \\
\text { reflected on } \\
\text { strengths and } \\
\text { weaknesses } \\
\text { of their } \\
\text { design and/ } \\
\text { or (2) their } \\
\text { product was } \\
\text { appreciated } \\
\text { by others. }\end{array}$ \\
\hline Examples: & Examples: & Examples: & Examples: & Examples: & Examples: \\
\hline $\begin{array}{l}\text { Notes, } \\
\text { guided labs. }\end{array}$ & $\begin{array}{l}\text { A poster } \\
\text { about } \\
\text { weather, } \\
\text { when the } \\
\text { assignment } \\
\text { was about } \\
\text { genetics. }\end{array}$ & $\begin{array}{l}\text { A poster that } \\
\text { shows the } \\
\text { stages of } \\
\text { mitosis. } \\
\text { A word } \\
\text { search that } \\
\text { contains } \\
\text { genetics } \\
\text { terms. }\end{array}$ & $\begin{array}{l}\text { Educational } \\
\text { game or poster } \\
\text { that raises } \\
\text { awareness } \\
\text { about } \\
\text { genetically } \\
\text { modified } \\
\text { foods. }\end{array}$ & $\begin{array}{l}\text { A prototype } \\
\text { of an app } \\
\text { that supports } \\
\text { parents with } \\
\text { a genetic } \\
\text { mutation } \\
\text { making } \\
\text { decisions } \\
\text { about having } \\
\text { a child. }\end{array}$ & $\begin{array}{l}\text { The app } \\
\text { (mentioned to } \\
\text { the left), with } \\
\text { a letter of } \\
\text { support from } \\
\text { a user, and/ } \\
\text { or a written } \\
\text { reflection on } \\
\text { strengths and } \\
\text { weaknesses of } \\
\text { the product. }\end{array}$ \\
\hline
\end{tabular}




\begin{tabular}{|c|c|c|c|c|c|}
\hline N/A & 0 & 1 & 2 & 3 & 4 \\
\hline $\begin{array}{l}\text { Not a } \\
\text { science } \\
\text { lesson. }\end{array}$ & $\begin{array}{l}\text { Student } \\
\text { didn't do } \\
\text { anything that } \\
\text { resembles } \\
\text { a scientific } \\
\text { investigation } \\
\text { (i.e., an } \\
\text { empirical/ } \\
\text { theoretical } \\
\text { experiment, } \\
\text { dissection, or } \\
\text { fieldwork). }\end{array}$ & $\begin{array}{l}\text { Student did a } \\
\text { small aspect } \\
\text { of a scientific } \\
\text { investigation. }\end{array}$ & $\begin{array}{l}\text { Student did } \\
\text { a majority of } \\
\text { a scientific } \\
\text { investigation. }\end{array}$ & $\begin{array}{l}\text { Student did } \\
\text { a majority of } \\
\text { a scientific } \\
\text { investigation. } \\
\text { In addition, } \\
\text { student made } \\
\text { reference } \\
\text { to a larger } \\
\text { (scientific } \\
\text { or practical) } \\
\text { question to } \\
\text { which their } \\
\text { investigation } \\
\text { was relevant. }\end{array}$ & $\begin{array}{l}\text { Student did } \\
\text { a majority of } \\
\text { a scientific } \\
\text { investigation. } \\
\text { In addition, } \\
\text { student made } \\
\text { reference } \\
\text { to a larger } \\
\text { (scientific } \\
\text { or practical) } \\
\text { question to } \\
\text { which their } \\
\text { investigation } \\
\text { was relevant. } \\
\text { In addition, } \\
\text { student } \\
\text { clearly and } \\
\text { correctly } \\
\text { explained } \\
\text { how their } \\
\text { scientific } \\
\text { investigation } \\
\text { informed } \\
\text { their larger } \\
\text { question. }\end{array}$ \\
\hline & $\begin{array}{l}\text { Examples: } \\
\text { Notes on } \\
\text { genes } \\
\text { Practice } \\
\text { problems on } \\
\text { balancing } \\
\text { equations }\end{array}$ & $\begin{array}{l}\text { Examples: } \\
\text { Extended } \\
\text { analysis } \\
\text { questions on } \\
\text { genetics. } \\
\text { Using } \\
\text { simulations } \\
\text { that help } \\
\text { conceptualize } \\
\text { molecular } \\
\text { motion. } \\
\text { Close } \\
\text { observation } \\
\text { of a squirrel's } \\
\text { behavior for } \\
\text { five minutes } \\
\text { without } \\
\text { making } \\
\text { meaning. }\end{array}$ & $\begin{array}{l}\text { Examples: } \\
\text { Students } \\
\text { record data } \\
\text { and come } \\
\text { up with } \\
\text { inferences. } \\
\text { Students } \\
\text { dissect a squid. } \\
\text { Close } \\
\text { observation } \\
\text { of a squirrel's } \\
\text { behavior and } \\
\text { come up } \\
\text { with some } \\
\text { inferences } \\
\text { or scientific } \\
\text { questions. }\end{array}$ & $\begin{array}{l}\text { Examples: } \\
\text { Used analysis } \\
\text { of molecular } \\
\text { structure of } \\
\text { chemicals } \\
\text { in pesticides } \\
\text { to help } \\
\text { recommend } \\
\text { the best } \\
\text { pesticide for } \\
\text { the school } \\
\text { garden. } \\
\text { Relied on } \\
\text { experimental } \\
\text { relationship } \\
\text { between } \\
\text { temperature } \\
\text { and pressure to } \\
\text { argue how it's } \\
\text { important to } \\
\text { attend to the } \\
\text { thickness of } \\
\text { a space } \\
\text { shuttle's wall. }\end{array}$ & $\begin{array}{l}\text { Example: } \\
\text { Student } \\
\text { does what's } \\
\text { described } \\
\text { under \#3, } \\
\text { and clearly } \\
\text { conveys how } \\
\text { the solution } \\
\text { to their bigger } \\
\text { question is } \\
\text { informed by } \\
\text { their science } \\
\text { investigation. }\end{array}$ \\
\hline
\end{tabular}

Note: NGSS practices are described here. For this dimension, exclude "obtaining and communicating information," which is assessed in S4. 
Student Work Dimension 3: Student(s) made sound use of the three major stages of the engineering design process (i.e., define, develop solutions, optimize)

\begin{tabular}{|c|c|c|c|c|c|}
\hline N/A & 0 & 1 & 2 & 3 & 4 \\
\hline $\begin{array}{l}\text { Not an } \\
\text { engineering } \\
\text { lesson }\end{array}$ & $\begin{array}{l}\text { Student } \\
\text { didn't use any } \\
\text { part of the } \\
\text { engineering } \\
\text { design } \\
\text { process. }\end{array}$ & $\begin{array}{l}\text { Student } \\
\text { successfully } \\
\text { conducted } \\
\text { some aspects } \\
\text { of the } \\
\text { engineering } \\
\text { design process } \\
\text { but did not } \\
\text { create an } \\
\text { actual product. }\end{array}$ & $\begin{array}{l}\text { Student } \\
\text { successfully } \\
\text { conducted } \\
\text { some aspects } \\
\text { of the } \\
\text { engineering } \\
\text { design process. } \\
\text { Student } \\
\text { created a } \\
\text { prototype } \\
\text { or product. }\end{array}$ & $\begin{array}{l}\text { Student } \\
\text { successfully } \\
\text { conducted } \\
\text { some } \\
\text { aspects of an } \\
\text { engineering } \\
\text { design process. } \\
\text { Student } \\
\text { created a } \\
\text { prototype or } \\
\text { product. } \\
\text { The prototype } \\
\text { or product is } \\
\text { accompanied } \\
\text { with some } \\
\text { descriptions/ } \\
\text { specifications } \\
\text { of the design. }\end{array}$ & $\begin{array}{l}\text { Student } \\
\text { successfully } \\
\text { conducted } \\
\text { most aspects } \\
\text { of an } \\
\text { engineering } \\
\text { design } \\
\text { process. } \\
\text { Student } \\
\text { created a } \\
\text { prototype or } \\
\text { product. } \\
\text { The prototype } \\
\text { or product is } \\
\text { accompanied } \\
\text { by } \\
\text { compelling } \\
\text { descriptions/ } \\
\text { specifications } \\
\text { of the design } \\
\text { (e.g., reasons } \\
\text { the design } \\
\text { is good, } \\
\text { explanation } \\
\text { that the } \\
\text { product is } \\
\text { based on a } \\
\text { systematic } \\
\text { design } \\
\text { process). }\end{array}$ \\
\hline & $\begin{array}{l}\text { Example: } \\
\text { Proposed a } \\
\text { solution to } \\
\text { a problem } \\
\text { without any } \\
\text { research } \\
\text { about } \\
\text { the problem. }\end{array}$ & $\begin{array}{l}\text { Example: } \\
\text { Generated } \\
\text { ideas and/or } \\
\text { researched } \\
\text { what might } \\
\text { be relevant to } \\
\text { designing } \\
\text { a solution. }\end{array}$ & & & \\
\hline
\end{tabular}


Student Work Dimension 4. Student(s) critically researched existing information

(Aligned with NGSS middle school standards on obtaining information: https://ngss.nsta.org/Practices.aspx?id=8)

\begin{tabular}{|c|c|c|c|c|c|}
\hline $\mathrm{N} / \mathrm{A}$ & 0 & 1 & 2 & 3 & 4 \\
\hline $\begin{array}{l}\text { Student was } \\
\text { not asked } \\
\text { to research } \\
\text { existing } \\
\text { information. }\end{array}$ & $\begin{array}{l}\text { Student } \\
\text { obtained } \\
\text { information } \\
\text { from only a } \\
\text { single source. }\end{array}$ & $\begin{array}{l}\text { Student } \\
\text { obtained } \\
\text { information } \\
\text { from multiple } \\
\text { sources. } \\
\text { Some sources } \\
\text { were not } \\
\text { appropriate } \\
\text { or student } \\
\text { simply copied } \\
\text { information. }\end{array}$ & $\begin{array}{l}\text { Student } \\
\text { obtained } \\
\text { information } \\
\text { from multiple } \\
\text { sources. } \\
\text { Most/all } \\
\text { sources were } \\
\text { appropriate. } \\
\text { Student } \\
\text { combined } \\
\text { information } \\
\text { from multiple } \\
\text { sources to } \\
\text { form answers } \\
\text { expressed } \\
\text { using his/her } \\
\text { own words. }\end{array}$ & $\begin{array}{l}\begin{array}{l}\text { Student } \\
\text { obtained } \\
\text { information } \\
\text { from multiple } \\
\text { sources. }\end{array} \\
\text { All sources } \\
\text { were } \\
\text { appropriate. } \\
\text { Student } \\
\text { combined the } \\
\text { information } \\
\text { from multiple } \\
\text { sources to } \\
\text { explain a } \\
\text { phenomenon } \\
\text { or suggest } \\
\text { a solution } \\
\text { to a design } \\
\text { problem. }\end{array}$ & $\begin{array}{l}\text { Student obtained } \\
\text { information from } \\
\text { multiple sources. } \\
\text { All sources were } \\
\text { appropriate. } \\
\text { Student } \\
\text { combined the } \\
\text { information from } \\
\text { multiple sources } \\
\text { to explain a } \\
\text { phenomenon } \\
\text { or suggest a } \\
\text { solution to a } \\
\text { design problem. } \\
\text { Student } \\
\text { demonstrated } \\
\text { attention to } \\
\text { the credibility, } \\
\text { accuracy, and } \\
\text { possible bias of } \\
\text { the publications } \\
\text { and methods } \\
\text { used. }\end{array}$ \\
\hline
\end{tabular}

Student Work Dimension 5: The organization, style, and format of the student's work is effective.

\begin{tabular}{|c|c|c|c|c|c|}
\hline N/A & 0 & 1 & 2 & 3 & 4 \\
\hline $\begin{array}{l}\text { Student(s) } \\
\text { were not } \\
\text { tasked with } \\
\text { work where } \\
\text { organization, } \\
\text { style, and } \\
\text { format } \\
\text { matter. }\end{array}$ & $\begin{array}{l}\text { The work is } \\
\text { incomplete, } \\
\text { and/or so } \\
\text { disorganized } \\
\text { that the } \\
\text { teacher/ } \\
\text { audience } \\
\text { cannot tell } \\
\text { what i } \\
\text { going on. }\end{array}$ & $\begin{array}{l}\text { The work is } \\
\text { complete. } \\
\text { There is an } \\
\text { attempt at } \\
\text { organization, } \\
\text { but it's not very } \\
\text { effective. }\end{array}$ & $\begin{array}{l}\text { Organization } \\
\text { of the work } \\
\text { makes sense, } \\
\text { but the format } \\
\text { and style is not } \\
\text { very effective. }\end{array}$ & $\begin{array}{l}\text { Effective } \\
\text { organization, } \\
\text { format and } \\
\text { style. } \\
\text { Meets } \\
\text { expectations. }\end{array}$ & $\begin{array}{l}\text { Very effective } \\
\text { organization, } \\
\text { format and style. } \\
\text { Exceeds } \\
\text { expectations. }\end{array}$ \\
\hline
\end{tabular}

Note: This is a generic rubric that can be used to assess a variety of communication products, including presentations, video products, artwork and posters. For classroom use, teachers should provide students in advance with additional details on what constitutes "meets expectations," based on the assignment. 


\section{Appendix D. Rubrics Used to Assess Opportunities and Outcomes of Learning Grade-Appropriate Disciplinary Core Ideas}

Activity Dimension on Science Content: Activity calls for students to understand grade-appropriate disciplinary core ideas.

This dimension is about alignment of content knowledge to the NGSS disciplinary core ideas. To use this dimension, it's necessary to assess how the content maps to relevant NGSS disciplinary core ideas from the list here.

\begin{tabular}{|c|c|c|c|c|}
\hline 0 & 1 & 2 & 3 & 4 \\
\hline $\begin{array}{l}\text { Activity is } \\
\text { unrelated to any } \\
\text { of the disciplinary } \\
\text { core ideas that } \\
\text { middle school } \\
\text { students are } \\
\text { expected to learn. }\end{array}$ & $\begin{array}{l}\text { Activity is related } \\
\text { to disciplinary } \\
\text { core ideas, but } \\
\text { it's unclear what } \\
\text { they are. }\end{array}$ & $\begin{array}{l}\text { Activity calls } \\
\text { for students } \\
\text { to learn } \\
\text { disciplinary core } \\
\text { ideas, but the } \\
\text { scope, level, or } \\
\text { scaffolds are off } \\
\text { (e.g., too many/ } \\
\text { few standards; } \\
\text { expectations are } \\
\text { too high or } \\
\text { too low). }\end{array}$ & $\begin{array}{l}\text { Activity calls } \\
\text { for students to } \\
\text { learn disciplinary } \\
\text { core ideas at } \\
\text { an appropriate } \\
\text { pace, scope, } \\
\text { and inclusion of } \\
\text { scaffolds. }\end{array}$ & $\begin{array}{l}\text { Activity calls } \\
\text { for students to } \\
\text { learn disciplinary } \\
\text { core ideas at an } \\
\text { appropriate pace } \\
\text { and scope. } \\
\text { Activity is } \\
\text { impressive in } \\
\text { its inclusion of } \\
\text { core ideas. }\end{array}$ \\
\hline Example: & Example: & Example: & & Example: \\
\hline $\begin{array}{l}\text { Activity on how } \\
\text { to use an app to } \\
\text { create cartoons. }\end{array}$ & $\begin{array}{l}\text { Egg drop } \\
\text { experiment with } \\
\text { no discussion on } \\
\text { what the point } \\
\text { of it was. }\end{array}$ & $\begin{array}{l}\text { Middle school } \\
\text { students needing } \\
\text { to calculate } \\
\text { of carrying } \\
\text { capacity. } \\
\text { A lesson that } \\
\text { takes a week } \\
\text { to convey only } \\
\text { that gravitational } \\
\text { forces (only) } \\
\text { attract. }\end{array}$ & & $\begin{array}{l}\text { Activity that } \\
\text { effectively, } \\
\text { efficiently, } \\
\text { or creatively } \\
\text { includes } \\
\text { core ideas. }\end{array}$ \\
\hline
\end{tabular}


Student Work Dimension on Science Content: Student(s) demonstrated a sound understanding of relevant disciplinary core ideas

To use this rubric, it's necessary to separately articulate the level of understanding that is expected at the middle school level, for example, by selecting the relevant NGSS disciplinary core ideas from the list here.

\begin{tabular}{|c|c|c|c|c|c|}
\hline $\mathrm{N} / \mathrm{A}$ & 0 & 1 & 2 & 3 & 4 \\
\hline $\begin{array}{l}\text { Students were } \\
\text { not asked to } \\
\text { demonstrate } \\
\text { the } \\
\text { connection } \\
\text { of their work } \\
\text { with relevant } \\
\text { content } \\
\text { knowledge. }\end{array}$ & $\begin{array}{l}\text { Demonstrates } \\
\text { little/no } \\
\text { understanding } \\
\text { of the relevant } \\
\text { disciplinary } \\
\text { core ideas. } \\
\text { Serious errors. }\end{array}$ & $\begin{array}{l}\text { Demonstrates } \\
\text { some } \\
\text { understanding } \\
\text { of the relevant } \\
\text { disciplinary } \\
\text { core ideas. } \\
\text { At least one } \\
\text { major error. }\end{array}$ & $\begin{array}{l}\text { Demonstrates } \\
\text { some } \\
\text { understanding } \\
\text { of the relevant } \\
\text { disciplinary core } \\
\text { ideas. } \\
\text { No major } \\
\text { errors. }\end{array}$ & $\begin{array}{l}\text { Demonstrates } \\
\text { a solid } \\
\text { understanding } \\
\text { of the relevant } \\
\text { disciplinary } \\
\text { core ideas. } \\
\text { No major } \\
\text { errors. }\end{array}$ & $\begin{array}{l}\text { Demonstrates } \\
\text { a solid } \\
\text { understanding } \\
\text { of the relevant } \\
\text { disciplinary } \\
\text { core ideas. } \\
\text { No major } \\
\text { errors. } \\
\text { Understanding } \\
\text { is deeper or } \\
\text { more nuanced } \\
\text { than would } \\
\text { be expected } \\
\text { at the middle } \\
\text { school level. }\end{array}$ \\
\hline
\end{tabular}




\section{Appendix E. List of OER Found and Explored by Project Teachers}

\begin{tabular}{|c|c|c|}
\hline OER found & Brief description & What teachers liked/disliked \\
\hline Phenomena Database & $\begin{array}{l}\text { Database of NGSS science } \\
\text { phenomena }\end{array}$ & $\begin{array}{l}\text { Vast quantity, but still easy to } \\
\text { explore }\end{array}$ \\
\hline $\begin{array}{l}\text { Greenhouse Effect } \\
\text { Simulator }\end{array}$ & $\begin{array}{l}\text { Phet simulation on greenhouse } \\
\text { effect }\end{array}$ & $\begin{array}{l}\text { Easy to understand. Good visual } \\
\text { learning piece }\end{array}$ \\
\hline $\begin{array}{l}\text { https://phet.colorado.edu/ } \\
\text { sims/html/color-vision/ } \\
\text { latest/color-vision_en.html }\end{array}$ & Phet simulation on color vision & $\begin{array}{l}\text { Easy to use. Additional resource } \\
\text { to support how to interpret light } \\
\text { and color. }\end{array}$ \\
\hline https://www.learner.org/ & $\begin{array}{l}\text { Teacher resources and PD across } \\
\text { the curriculum by Annenberg } \\
\text { Learner (division of Annenberg } \\
\text { Foundation) }\end{array}$ & Variety of plans/topics \\
\hline $\begin{array}{l}\text { https://www. } \\
\text { amoebasisters.com/ }\end{array}$ & $\begin{array}{l}\text { Science related videos, GIFs, } \\
\text { comics, etc., created by the } \\
\text { Amoeba Sisters, who "love } \\
\text { empowering teacher and student } \\
\text { creators" and want to demystify } \\
\text { science. }\end{array}$ & $\begin{array}{l}\text { Used in the past, variety of bio } \\
\text { related videos and handouts to } \\
\text { accompany videos }\end{array}$ \\
\hline $\begin{array}{l}\text { Stanford NGSS Integrated } \\
\text { Curriculum by SCALE }\end{array}$ & $\begin{array}{l}\text { "Integrated, NGSS-designed, } \\
\text { project-based curriculum for 7th } \\
\text { and 8th grade." }\end{array}$ & $\begin{array}{l}\text { Middle school lessons. Difficult to } \\
\text { identify whether or not it's open }\end{array}$ \\
\hline $\begin{array}{l}\text { https://www.oercommons. } \\
\text { org/courses/who-s- } \\
\text { hitchhiking-in-your-food }\end{array}$ & gr6-9 lesson for bacteria in food & $\begin{array}{l}\text { Middle school lesson for bacteria } \\
\text { in food }\end{array}$ \\
\hline Animal Hearing (PBS \& OER) & $\begin{array}{l}\text { Shark senses compared to other } \\
\text { animals' senses } \\
\text { Animal hearing } \\
\text { Video on hearing loss (humans) }\end{array}$ & \\
\hline $\begin{array}{l}\text { Open Professionals } \\
\text { Education Network }\end{array}$ & $\begin{array}{l}\text { A resource hub with links to many } \\
\text { resources that are OER }\end{array}$ & $\begin{array}{l}\text { A central place to use as a search } \\
\text { platform for different websites } \\
\text { that provide OER videos, } \\
\text { pictures, websites, etc. }\end{array}$ \\
\hline OER Commons & Big repository of OER & Good search features \\
\hline Open4us.org & $\begin{array}{l}\text { TED talks, clipart, and other } \\
\text { resources that is open }\end{array}$ & $\begin{array}{l}\text { Gives you what is approved by } \\
\text { OER }\end{array}$ \\
\hline $\begin{array}{l}\text { Filters on YouTube/Google to } \\
\text { get "Creative Commons" }\end{array}$ & & $\begin{array}{l}\text { Filter tends to retrieve results of } \\
\text { uneven quality }\end{array}$ \\
\hline
\end{tabular}

